\title{
RULING OR BEING RULED? \\ THE DEVELOPMENT OF CITIZENSHIP IN THE CHEROKEE NATION
}

A Dissertation
presented to
the Faculty of the Graduate School
at the University of Missouri-Columbia
In Partial Fulfillment
of the Requirements for the Degree
Doctor of Philosophy
AARON KUSHNER
Dr. Justin Dyer, Dissertation Supervisor
JULY




\section{DEDICATION}

..To Mary Ann and Robert Kushner. You saw in me something special.

...To Ryan, Daniel, and Tommy. You are the best of friends.

To Nhi, G, Lea, Dale, and Christopher. I couldn't ask for better family.

To Hannah. You are all beauty and color and light.

..Gloria Patri, et Filio, et Spiritui Sancto. Sicut erat in principio, et nunc, et semper, et in saecula saeculorum. Amen. 


\section{ACKNOWLEDGEMENTS}

I would like to thank Professor Justin Dyer for his mentorship and guidance throughout this dissertation project. Without his wisdom, kindness, and encouragement, none of this would have been possible. I also want to acknowledge Professor Adam Seagrave, who mentored me at Northern Illinois University and again here at the University of Missouri. His insight and advice have been an invaluable part of my professional development. Thank you to Professor Sarah Beth Kitch, who gave generously of her time to help me improve the quality of my writing. Thank you as well to dissertation committee members Marvin Overby and Jay Dow for all of your time and ongoing support.

Additional thanks are due to Professors Scot Schraufnagel, Brad Watson, Jason King, Laron Williams, and Jason Jividen, who mentored and supported me at various stages of my academic career. Thank you for believing in me.

Special thanks to those other scholars who have had a great influence on my growth as a graduate student: Stephen Clouse, Luke Perez, Dongjin Kwak, Yuko Sato, and Katherine Becerra. I am grateful for your critical advice, conversation, and friendship.

Thank you also to the Kinder Institute on Constitutional Democracy, especially Allison Smythe, Thomas Kane, Jay Sexton, and Jeff Pasley. Without each of you putting in the effort to make the Kinder Institute an excellent place to study, learn, and be, none of this would have been possible. 


\section{CONTENTS}

ACKNOWLEDGEMENTS ............................................................................... ii

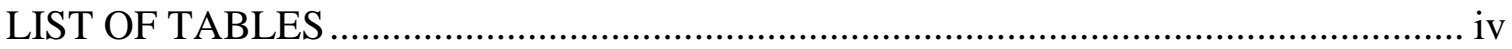

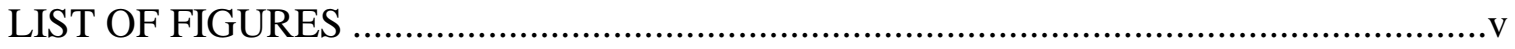

ABSTRACT

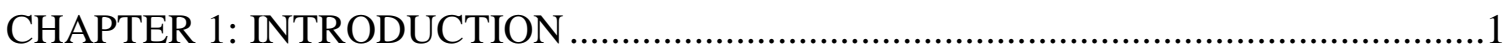

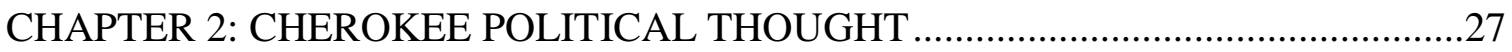

CHAPTER 3: TOWARD THE SITTING SUN: AN ANALYSIS OF FEDERAL

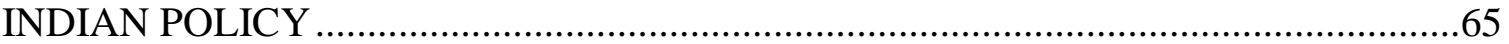

CHAPTER 4: AMERICAN INSTITUTIONS AND CHEROKEE POLITICAL

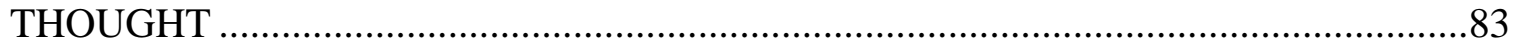

CHAPTER 5: WRITTEN IN BLOOD: TRIBAL CITIZENSHIP AND THE

CHEROKEE FREEDMEN

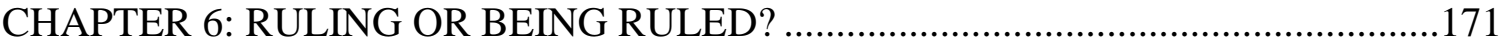

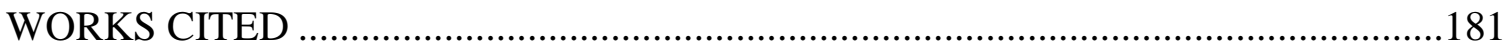

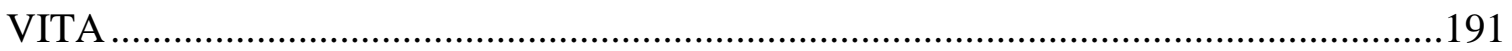




\section{LIST OF TABLES}

Table 2.1 Shifts in Cherokee Citizenship, 1866-2018 ............................................61

Table 3.1 Overview of Federal Indian Policy by Time Period ....................................69

Table 4.1 A Comparison of American and Cherokee Political Values, 1827-1865 ........95

Table 5.1 Comparing Freedmen's Views of Citizenship in Two Periods.....................160 


\section{LIST OF FIGURES}

Figure 1.1 Theory of Cherokee Citizenship Development ..........................................19

Figure 2.1 A Pyramid of Cherokee Political Thought ...............................................40

Figure 2.2 Percentage of Total Cherokee Legislation on Citizenship, 1976-2018 _..........56

Figure 3.1. Federal Policy and Cherokee Citizenship Timeline, 1787-1827 ..................76

Figure 3.2 Federal Policy and Cherokee Citizenship Timeline, 1827-1866...................78

Figure 3.3 Federal Policy and Cherokee Citizenship Timeline, 1866-1934 ...................79

Figure 3.4 Federal Policy and Cherokee Citizenship Timeline, 1934-2019...................81 


\begin{abstract}
What does it mean to be a member of a tribal government in the United States? This dissertation answers that question with an analysis of Cherokee citizenship, both as a concept and as a legal condition. Previous work on the Cherokee has been historical, anthropological, or sociological in nature. Political scientists have not yet produced a study of Cherokee citizenship. I fill in this gap in the literature by approaching Cherokee citizenship from three different angles - from the perspective of the Cherokee, of United States officials, and from the descendants of freedmen who live in the Cherokee Nation. I argue that the prevailing explanations for the state of Cherokee citizenship, racial prejudice and acquisitiveness, do not paint a complete picture. Instead, these explanations need to be supplemented with an understanding of the ideological incongruence between Cherokee and American political thought. My ideological incongruence thesis posits that inherent differences between the Cherokee and the United States over how to understand and practice politics has led to struggles over Cherokee citizenship and has subsequently driven the development of Cherokee law. A holistic view of Cherokee citizenship admits three major factors at play—racial prejudice, material acquisitiveness, and ideological tension. This holistic view can help scholars parse through difficult dimensions of indigenous-US relations and lend clarity to debates over the status of tribal governments and their people.
\end{abstract}




\section{Chapter 1: Introduction}

Being Cherokee is "a question of commitment," wrote Jason Tarrell to the Cherokee Observer in 1996, "it's the way you live and the way your family has lived...you can't suddenly become Cherokee. It's not a club." ${ }^{1}$ The Cherokee people, through a supreme effort of will and a resiliency of spirit, have remained an intact political community for the past two hundred and thirty-two years - this despite US government policy's constant challenges to group identity and cohesion. Of course, the Cherokee, as they are today known, have been around much longer than $1787 .^{2}$ The past two hundred and thirty-two years dealing with the United States, however, have forced the Cherokee to adapt their political community to retain critical elements of their belief systems about the sacred in an increasingly urbanizing world. One of their greatest challenges, as Tarrell's comment implies, has been identifying and articulating what it means to be Cherokee. The creation of a Cherokee constitutional government, and the concept of legal tribal citizenship, in the 1820 s made that challenge even more complicated. The goal of this dissertation is to understand Cherokee citizenship by analyzing the underlying ideas that have influenced its creation.

An overview of the literature suggests that the Cherokee self-govern under the surveillance of US oversight committees and federal agencies, who have historically displayed confusion when it comes to Indian politics (Prucha 1976; Littlefield 1978;

\footnotetext{
${ }^{1}$ Jason Tarrell, "Editorial from a Member," Cherokee Observer, 4 no. 4, April 1996.

${ }^{2}$ According to historian Robert Conley, some estimates claim that the ancestors of the Cherokee immigrated to America via the Bering Strait land-bridge some twelve thousand years ago and established the first communities $(2005,1)$. While some scholars begin their histories of the Cherokee people with first contact with Europeans in the 1690s (McLoughlin 1986, 3), the Cherokee existed as a vibrant community long before first contact with white civilization and certainly much earlier than the creation of the United States (Purdue 1998, 13).
} 
French 2016). American politicians have historically tended toward belligerence against peoples that they do not understand (Kettner 1978; Limerick 1987). When scholars have attempted to analyze this American confusion over what to do with indigenous peoples, they have largely explained it by censuring racial prejudice or acquisitiveness or both (Fritz 1963; Green 1982; Sturm 2002; Castile 2006; Fletcher 2011; French 2016). These the Cherokee have endured, weathering the storm of persecution to find a light of their own making. Of course, the Cherokee themselves have not been immune from engaging in their own belligerence against other groups (Sturm 1998). Racial prejudice and material acquisitiveness are not foreign to the Cherokee either, as evidenced by some of their governmental actions toward their formerly enslaved peoples (Littlefield 1978; Sturm 2002).

Another critical contributor to the American confusion over Indian affairs, one that scholars have spent too little time considering, is the ideological distance between American and Cherokee political thought. Racial prejudice and material acquisitiveness (read as prioritizing economic matters over human lives) have, of course, played an significant role in shaping both American attitudes and policy toward the Cherokee, as well as the Cherokees' own actions (Halliburton 1977; Gross 1989; Hoxie 1989; Smith 1997; Purdue 2016). But these explanations alone fail to paint a full picture of USCherokee relations. Consider the case of the Cherokee freedmen, descendants of formerly enslaved peoples living in the Cherokee Nation. ${ }^{3}$ The Cherokee have resisted

\footnotetext{
${ }^{3}$ Allison Herrera, "In Limbo: Descendants of Cherokee Freedmen Seek Recognition," KOSU, Invisible Nations, February 2016. In the interview, Will Chavez, the long-time editor of the Cherokee Phoenix who has covered the Cherokee freedmen saga for over ten years, stated that the number of individuals affected by the Cherokee denying descendants of freedmen the vote is about 28,000 .
} 
incorporating them as citizens since the US forced them to in $1866 .{ }^{4}$ Why has this happened?

The material acquisitiveness explanation reveals part of the story. After gaining their freedom at the end of the Civil War, the Cherokee freedmen found themselves desperate for a home (Littlefield 1978; Minges 2004). The United States at the end of the war was undertaking the massive effort to care for the countless freedmen already scattered across the nation, whose destitution was "too appalling for belief" (Du Bois 1994, 11). US officials, not desiring to extend the federal government further by adopting former slaves once held by Indians, commanded the Cherokee, a conquered people who had sided with the Confederacy, to adopt their own freedmen into full tribal citizenship (Halliburton 1977, 134-135). United States officials would go on to use the freedmen's cries for assistance in dealing with the Cherokee as an excuse to take control over more Cherokee land at the end of the $19^{\text {th }}$ Century (Wardell 1938, 229-231; Bailey 1972, 181 182). The United States today, however, does not accumulate Cherokee lands the way that it did in previous centuries. The Cherokee Nation currently receives financial benefits from its relationship with the United States (Sturm 2002; 2014). Historically, the Cherokee have not wanted to share these benefits, often in the form of payouts for land, with the freedmen (Wardell 1938; Bailey 1972; Littlefield 1978). Yet this explanation does not answer why the early Cherokee constitutions were constructed to exclude

\footnotetext{
${ }^{4}$ The Treaty of 1866 was signed by the United States and the Cherokee after the Civil War, officially ending hostilities between the two parties (Halliburton 1977, 133-136). The treaty stipulated that the Cherokee would include all freedmen and free blacks living in the Cherokee Nation as full legal citizens, provided that these individuals return to and reside in the Nation within six months of the signing (Halliburton 1977, 136). The Cherokee, in response, chose to strictly interpret and enforce the six month provision of the treaty, to avoid admitting more freedmen and blacks than they had to (Sturm 2002).
} 
freedmen or why some Cherokee politicians persist in desiring a Cherokee-by-blood-only community.

The racial prejudice thesis reveals a little more truth, especially when combined with the greed explanation. In the early republic, the way US law was written was racially prejudiced against Indians and prevented them from obtaining citizenship, even when tribal peoples wanted to become American citizens (Kettner 1978, 293-299; Smith 1997, 181, 235-237). While many in the United States roundly dismissed tribal peoples as savages, typified perhaps in the writings of Andrew Jackson, James Madison once remarked how "the Savages...have a particular antipathy toward the blacks" as well (2015, 228). The Cherokee themselves, in their first written Constitution, did employ racially charged language to justify the exclusion of blacks from their political society. ${ }^{5}$ Today, in the modern disputes over blood politics - the potential use of blood quantum to determine who is Cherokee - Circe Sturm has argued that there is a definitive racial element to the Cherokee refusal to fully incorporate, socially as well as politically, the freedmen $(2002,1-3) .{ }^{6}$ Yet something is missing from these the racial and greed narratives, even when joined together. ${ }^{7}$ They do not fully explain why the Cherokee have resisted citizenship for the freedmen.

\footnotetext{
${ }^{5}$ Elias Boudinot, "Constitution of the Cherokee Nation," The Cherokee Phoenix 1 no. 1, February 21, 1828.

${ }^{6}$ The Cherokee, as of 2019, do not use blood quantum to determine tribal citizenship. "According to tribal law, Cherokee citizens must be lineal descendants of an enrolled tribal member [a name listed on the Dawes Rolls], but no minimum blood quantum is required" (Sturm 2002, 2).

${ }^{7}$ In 2007, Rep. Diane Watson (D-CA) introduced a bill designed to sever US financial ties with the Cherokee because the Cherokee had recently passed a constitutional amendment that essentially gave them the authority to disenfranchise the freedmen who were not listed on the Dawes Rolls ( $A$ Bill to Sever United States' Government Relations with the Cherokee Nation of Oklahoma, HR 2824, $110^{\text {th }}$ Cong., $1^{\text {st }}$ sess., Congressional Record 153, no. 147, daily ed. [October 1, 2007]: H 11053.)

The text of Watson's bill described the long history of abuses, between the US and the Cherokee and the Cherokee and the freedmen, as predominantly the result of racism and greed. Watson did not,
} 
Why have the Cherokee so staunchly fought against the incorporation of a group of people unrelated by blood? Racial prejudice and acquisitiveness may explain particular episodes in the narrative fairly well-like the racist language used in the 1827 Cherokee Constitution and the Cherokee desire to retain federal payments for themselves-but these two factors do not fully explain why Cherokee citizenship looks the way that it does today. There are gaps in that limited narrative. Today, a Cherokee citizen is anyone who can prove relation to someone listed on the Dawes Rolls, both Cherokee and freedmen. ${ }^{8}$ In 1827, under the first Cherokee Constitution, a citizen was any Cherokee born of a Cherokee father or mother. That change is dramatic. For their part, the Cherokee have consistently shown their desire to remain a singular community, dedicated to their particular belief system and politics. An analysis of that Cherokee belief systemmanifested as Cherokee political thought, which I treat in chapter two-reveals a rationale for why the Cherokee exclusion of the freedmen from citizenship may appear, to many Americans, simply racist or greedy.

I argue that identifying, analyzing, and interpreting the ideological differences between Cherokee and American political thought permits a fuller understanding of Cherokee citizenship than that offered by racial prejudice and acquisitiveness

however, acknowledge that ideological differences between the Cherokee and United States may have played a role in the struggle.

${ }^{8}$ The Dawes Act of 1887 began the process of converting the communally held lands within the Cherokee Nation to lots of individual ownership, hoping to modernize the Cherokee and make room for more white settlement (Sturm 1998, 235). The Dawes Act also established the Dawes Commission that was sent to compile a roll of residents living in Indian Territory (Littlefield 1978, 238).

The Dawes Rolls broke down the residents of Cherokee land into three categories: Cherokee, whites, and freedmen. All told, the inhabitants of the Cherokee Nation numbered 41,798, including 4,924 freedmen (Littlefield 1978, 238). There were over 1,000 freedmen who had been citizens previously, however, that were excluded from the Dawes Rolls-due to a mixture of clerical errors, inability to produce proof of citizenship, and racial profiling (Sturm 1998). In 1902, the finals rolls closed and in 1907, the Cherokee Nation ceased to exist because Congress dissolved it when Oklahoma was admitted to the union. 
explanations. Perceived racist or greedy behaviors may be explained by clarifying ideological tensions. For example, the Cherokee have, for centuries, structured their political communities around the strength, safety, and happiness provided by the family (Stremlau 2011; Smithers 2015). The natural bonds of kinship marked the boundaries of their society. This familial community transitioned into a unified constitutional government in the 1820s but did not lose its affinity for consensus-based, family/clandriven politics. The first citizenship laws reflected that affinity. In fact, the Cherokee have consistently fought to protect the kinship-politics favored by their ancestors (Mankiller and Wallis 1993). United States politicians, either not understanding the Cherokee brand of politics—dismissively considering it savage or primitive—or understanding it and intending to change it, worked since the days of Washington to make the Cherokee conform to the image of American politics instead. ${ }^{9}$ Cherokee resilience in maintaining their form of government is testament to the strength of Cherokee political thought as an idea in the sense that it motivated behavior and provided a compelling ideology.

By realizing the fuller picture of Cherokee citizenship-what it is and how it came to be-scholars will be better able to pinpoint areas of conflict and politicians may come to policy solutions that more fully account for the unique political thought of the Cherokee. As James Tully argued, "if constitutionalism is approached from the perspective of the struggles of aboriginal peoples, unnoticed aspects of its historical formation and current limitations can be brought to light" and dealt with accordingly

\footnotetext{
${ }^{9}$ George Washington, in his annual messages to Congress, laid out his Indian policy, which included promoting attempts to civilize the indigenous peoples according to the level of civilization attained by the United States (George Washington, "Third Annual Message to Congress," October 25, 1791). The view of Washington, and many subsequent presidents, toward the Indians was paternalistic (Saltz 1975; Taylor 1983).
} 
$(1995,4)$. Through this new lens, American and Cherokee public discourse may be better-insulated against negativity and confusion, leading toward a more productive future. More importantly, however, the development of Cherokee citizenship is a story about a peoples' quest for identity, acceptance, sovereignty, and, at the most basic level, home. The Cherokee have long desired to remain a nation apart, a singular community, but the United States effectively prevented that by asserting authority over them, telling the Cherokee through policy, and sometimes directly, that their way of life was not good enough to exist in a civilized world. Today, the Cherokee and United States seem to have arrived at an uneasy truce. But tension between the two governments remains.

In the next section, I provide operative definitions of politics, the ancestral political tradition, and Cherokee political thought. As the controversy surrounding the Cherokee freedmen shows, many Americans approach the subject of indigenous peoples from a liberal perspective. By liberal perspective, I mean the standard political mores prevalent in the United States - most Americans view politics and citizenship through the lens of the liberal political tradition (Tocqueville 2000; Huntington 2004). Much of the nuance of indigenous politics, which stems from a non-liberal ancestral tradition, becomes distorted or lost when viewed only through an American liberal lens. Concrete definitions of ancestral politics and the Cherokee political tradition are therefore necessary to facilitate understanding and form the foundation of productive dialogue.

\section{The Cherokee Ancestral Political Tradition}

Politics is, at its core, a theory of the human person and how human beings may live together in harmony. Each individual, political by nature, associates with others for 
the sake of some good (Pol. 1252a2-3). ${ }^{10}$ The ancestral political tradition is not so distant from dominant western traditions in this respect. The good sought by many groups grounded in an ancestral tradition is "harmony and balance" between all living things (Mankiller and Wallis 1993, ix). Where the ancestral political tradition differs, however, is in the emphasis placed on different types of rule. As Aristotle recounts, the first political relationship is the family, man and woman, drawn together for the sake of reproduction and preservation (Pol. 1252a27-30). Husband, wife, children, and servants comprise the household - the "partnership constituted by nature for [the needs of] daily life" (Pol. 1252b13-14). Villages are composed of several households, united for the sake of non-daily needs. A village is a natural extension of the household; "kinship" defines the familial nature of the village (Pol. 1252b15-22). The complete partnership that arises from the union of several villages is what Aristotle termed the city, constituted for the sake of living well.

The Cherokee, during the Founding Era in the United States, lived in villages, understood in the Aristotelian sense. Cherokee political communities in the $18^{\text {th }}$ Century consisted of well-established villages, or towns - the Cherokee "defined a town as a group of people sharing the same ceremonial and council center" (Smithers 2015,6). Each Cherokee town had a special function. The chief of each town played a special role. For example, "Mother Towns were sites of clan leadership" where the red (war chief) or white (peace chief) presided over the town council (Smithers 2015, 6). The Cherokee clan structure, like town membership, was also critical to Cherokee life. Clan membership was based on matrilineal descent, meaning that "anyone born of a Cherokee

\footnotetext{
${ }^{10}$ References to The Politics are from the 1984 University of Chicago Press edition, translated by Carnes Lord; they are indicated by the Bekker numbers in parentheses.
} 
mother belonged to her clan and was a person with... [certain] obligations to other 'Real Human Beings,"” or Aniyunwiya (Stremlau 2011, 22). Clan membership was fixed and provided a stable support system. Even today, many Cherokee maintain that "having a Cherokee mother is the very key to Cherokee identity" (Sturm 2002, 28). There are seven matrilineal Cherokee clans, who all practiced exogamous marriage customs (Stremlau 2011, 22-23). ${ }^{11}$ This meant for the Cherokee an ordered, rather than a hierarchical, society based upon complex familial relationships (Sturm 2002; Stremlau 2011; Smithers 2015)..$^{12}$

To explain the Cherokee way of life, several histories of the Cherokee begin with the Cherokee creation story - the story of Selu (Corn) and Kanati (the Lucky Hunter), the first human beings called Aniyunwiya, "the real people" (Mankiller and Wallis 1993, 16; Awiakta 1993; Sturm 2002; Conley 2005). A profoundly spiritual people, the Cherokee believed that the world existed in a precarious balance, kept in order by right or correct actions (Wax and Wax 1978, 28-30; Mankiller and Wallis 1993, 19-20). Wrong actions would disturb that balance. ${ }^{13}$ These first red people, Selu and Kanati, personify the correct order of living, and show that blood is a "central metaphor for life" (Sturm 2002, 35). According to one tradition, Selu and Kanati "offer a cautionary tale about the power of blood" in both good and wrong actions (Hill 1997, 77). In the story, negligent bloodshed leads to the creation of a Wild Boy—-the personification of careless waste (Hill

${ }^{11}$ The seven Cherokee clans are "Aniwahya (Wolf Clan); Ani Tsiskwa (Small Bird Clan); Anikawi (Deer Clan); Anigilohi (Twister Clan); Anisahoni (Blue Clan); Anigatogewi (Wild Potato Clan); Aniwodi (Red Paint Clan)" (Smithers 2015, 6, emphasis in original).

${ }^{12}$ Scholars generally agree that the Cherokee community consisted of decentralized towns, regulated by clan affiliation, prior to their centralization under one Cherokee banner (Littlefield 1978; Sturm 2002; Minges 2003; Stremlau 2011).

${ }^{13}$ The "Indian view was of a world inhabited by beings" who possessed different powers powers that were sustained by ritual and could be transferred from being to being (Wax and Wax 1978, 28). As Murray and Rosalie Wax suggest, the "theology of this traditional world is addressed to the notion of maintaining a proper balance and harmony among its beings and powers" $(1978,30)$. 
1997, 77; Sturm 2002, 35). When Selu is eventually killed by her own son and the Wild Boy, her blood mixes with the earth and brings forth corn (Mooney 1900, 244-245), becoming a "metaphorical source of Cherokee life" (Sturm 2002, 35). The story illustrates the centrality of blood, a "powerful force in the Cherokee universe" (Sturm 2002, 35). Blood signified who was and who was not Cherokee (Awiakta 1993; Sturm 2002; Conley 2005).

We may observe from the way Cherokee society was structured, before it coalesced into a centralized government, a dedication to the public good. ${ }^{14}$ In the vein of Selu and Kanati, who "represented the ideal division of labor [between men and women] in society" and "modeled standards for proper behavior" (Stremlau 2011, 21), the Cherokee pursued an ordered community built upon "blood, kinship, language, and culture" (Sturm 2002, 36). Although decentralized, the Cherokee generally believed in the existence of a good life and that political societies may be structured to obtain that good life for their members. Cherokee townships existed, applying Aristotle's principle, for the sake of living well (Pol. 1252b29). While living well may have meant different things to a diverse Cherokee population (Smithers 2015), generally speaking, men and women each played distinct and critical roles within the family and clan community (Halliburton 1977, 8-9). The township organizations were loosely structured to naturally facilitate spiritual flourishing by allowing the Cherokee to freely interact with one another and the terrain. No institutions competed with the family for importance- the "expectations for hospitable and reciprocal interaction with family", broadly construed,

\footnotetext{
${ }^{14}$ Robert Conley, in his history of the Cherokee Nation, suggests that the ancient Cherokee once had a centralized government before it become corrupt and was overthrown in favor of the decentralized townships that Europeans encountered in the $16^{\text {th }}$ Century $(2005,17-22)$.
} 
shaped daily life (Stremlau 2011, 65). The perceived value of kinship associations was also not diminished by the creation of a centralized Cherokee government.

Up to this point, I have presented the Cherokee interpretation of the ancestral tradition as first, ethnocentric and second, as favoring a form of republicanism. The Cherokee had an ethnocentric view of politics—-foreignness determined their perceptions of outsiders, whom they largely considered inferior peoples (Halliburton 1977; Perdue 1979; Minges 2003; Saunt 2004). The Aniyunwiya possessed such strong kinship bonds that political society dedicated to the protection and preservation of their own was second-nature. Their society was also ordered, as in a republican government, for the cultivation of a kind of civic virtue, or public good. Again applying Aristotle's theory, the Cherokee lived together "for the sake of noble actions" and not merely "for the sake of living together" (Pol. 1281a42-43). ${ }^{15}$

\section{Cherokee Political Thought}

Conceptualizing the Cherokee brand of ancestral political thought presents an interesting challenge. The United States and the Cherokee Nation have been so intertwined —especially since the 1827 Cherokee Constitution—that teasing out unique Cherokee political innovations is difficult. Furthermore, ancient Cherokee society was governed by a particular set of "opinions and mores" that sometimes defy direct translation into English concepts (Tocqueville 2000, 1.2.10, 305). The principles of harmony and balance, for example, govern the relationships between all life on earth for

\footnotetext{
${ }^{15}$ I have found no evidence to suggest that the Cherokee read Aristotle during the formation of their constitutional government in the 1820s. Aristotelian concepts, however, due to their universality, map readily onto a study of the Cherokee people. It may be interesting to note though that many of the framers of the Cherokee Constitution were educated at American institutes of higher learning, where they had probably been exposed to classic texts (McLoughlin 1986, 366-369, 450).
} 
the Cherokee (Mankiller and Wallis 1993, ix). These principles, according to Wilma Mankiller, former chief of the Cherokee Nation, reflect the "interconnectedness of all living things" and ought to be adopted by all who wish a peaceful coexistence (Mankiller and Wallis 1993, xxiv). While the Cherokee have appropriated US legal customs over time, they have maintained a cultural commitment to their ancient identity and traditions in ways integral to both public and private life (Sturm 2002; Conley 2005; Stremlau 2011).

Cherokee political thought is different from the ancestral tradition. While pieces of the ancestral tradition may be found generally in the practices of many indigenous peoples, Cherokee political thought is the unique application of those pieces, a hybrid of both ancestral and American political principles. From the ancestral political tradition, the Cherokee retained a commitment to the Aristotelian notion of village politicsvillages as natural extensions of household rule (Pol. 1252b1-25). The commitment to small government systems based on kinship also kept prominent the Cherokee belief in the interconnectedness of all life, the idea that harmony and balance propels the world. From the American political tradition, the Cherokee took the idea of unified constitutional government, individual rights language, and the use of government apparatuses to regulate political life, as opposed to traditional methods of dealing with broken laws (French 2016, 8). ${ }^{16}$ There is concrete evidence of Cherokee political thought — a form of ethnic republicanism — in the nature of their laws once they established a unified constitutional government in the 1820 s.

\footnotetext{
${ }^{16}$ In general, the Indian justice system was based on avoiding overt hostility in interpersonal matters and nonaggressiveness in intra-familial/tribe/clan interactions (French 2016, 8). Intermediaries were used for resolving personal altercations and a general emphasis was placed on "group cooperation and not on individual competition" (French 2016, 8).
} 
As the political situation in North America changed, and the United States was formed, the Cherokee were faced with new challenges that drove them to reassess the sort of governing body needed to interact with white civilization (Moulton 1985; Conley 2005). In the Aristotelian sense, the Cherokee, who had lived in villages as kinsmen, were forced by white civilization to form a city, to unify politically. This political transformation was undeniably spurred on by white civilization; "it had become a diplomatic necessity to appropriate various forms of Western political discourse if they hoped to" protect their landholdings, livelihoods, and towns (Smithers 2015, 17). This long process of centralization culminated in the 1827 efforts to form a Cherokee Constitutional Convention (Moulton 1985). ${ }^{17}$

Cherokee political thought, as part of a legal tradition that continues today, was first reflected in that 1827 Cherokee Constitution. ${ }^{18}$ There is a distinct American influence on the document. The Cherokee crafted a constitution that included three branches of government with varying degrees of separation between them and an enumeration of individual rights. John Ross, who presided over the convention as president and who would later be elected Principal Chief, advocated for the move to a constitutional regime so that the Cherokee could deal with the United States on more of an equal legal footing (Moulton 1985, 34-36). This constitution, however, was also distinct enough to remain true to Cherokee values. A close reading of the 1827 Constitution reveals several significant differences between the US Constitution and the

\footnotetext{
${ }^{17}$ The centralization of Cherokee government, of course, was a long complex and nuanced process, the study of which is outside the scope of this dissertation. For more on this deep and engaging topic, see McLoughlin (1992), Perdue and Green (2007), and Conley (2005).

18 The Cherokee held a constitutional convention in the summer of 1827; the Constitution was ratified by representatives from each Cherokee district in July 1827, with John Ross presiding over the convention as president (Cherokee Phoenix, 1 no. 1, February 21, 1828).
} 
Cherokee document. I draw from these differences a more concrete connection between Cherokee political thought and ethnic republicanism, a connection explored more thoroughly in chapter two. For now, my purpose is to provide a brief overview to lay the groundwork for further analysis.

The position of honor in the 1827 Constitution is given to the land. Article I is dedicated to the preservation of the Cherokee homelands and explicitly states that the Cherokee lands are theirs, to be held in common, in perpetuity. ${ }^{19}$ The Cherokee "nuanced, layered understanding of the word "home" - defined in a collective sensewas reflected in their commitment to keep all lands held communally (Stremlau 2011, 95). ${ }^{20}$ Article I, Section 2 states that, while individuals may possess as private improvements - houses and other structures — on the land, they do not have the right to give lands held in common to those outside of the Nation. The land, in a sense, had the right to remain whole. The Cherokee focus on maintaining a commitment to the Old Ways, to holding lands in common to facilitate harmony and balance between man and nature (Awiakta 1993; Mankiller and Wallis 1993), was one of the driving forces behind Article I.

For the Cherokee, as stated above, individuals, families, and clans possessed specific societal roles intended to balance (order) the community (Littlefield 1978; Minges 2003). The 1827 Constitution legally clarified those roles. An individual best served the tribe by fulfilling their societal role - men were generally hunters and warriors supported by women who managed the households, tended the fields, and gathered food (Minges 2003). Given the belief in the sacred ties binding together society and nature

\footnotetext{
${ }^{19} \mathrm{lbid}$.

${ }^{20}$ The lands referred to in the 1827 Constitution were located in modern day Tennessee, North Carolina, Alabama, and Georgia (Perdue 2016, 22).
} 
(Wax and Wax 1978) — and the ancient confidence in Cherokee superiority (Halliburton $1977,139)$ - the adoption of legal blood politics in the $19^{\text {th }}$ Century makes intuitive sense. The 'public good' was something to be obtained for the Cherokee people, by the Cherokee people. The first Cherokee legal-constitutional-definition of citizenship reflected the commitment to creating a government by the Cherokee, for the Cherokee. Chapter two presents a detailed analysis of how citizenship developed across all four Cherokee constitutions. Throughout one hundred and fifty years of constitutional history, the Cherokee have maintained a commitment, albeit modified by interactions with the United States, to many of their ancestral political traditions.

The core tenets of Cherokee political thought then are hereditary citizenship, communally held lands, consent of the governed, popular sovereignty, and individual rights. Hereditary citizenship was essential for preserving unique Cherokee mores and keeping a common view of the public good intact. Communally held lands were valued for similar reasons, so that the community might continue their habits of mobility and growth. Consent of the governed and popular sovereignty were new-American-ways of expressing ideas that the Cherokee had had for generations but did not legally qualify. The Cherokee had long valued group consensus when making decisions, so these expressions made sense (French 2016, 8). Individual rights language was something slightly different, in that rights as the American first articulated them-protections against government action — would have been foreign to a people who saw politics, community, and family so closely intertwined (McLoughlin 1986, 3-6). 


\section{Cherokee Citizenship: A Matter of Blood and Tradition}

There is an important distinction between tribal citizenship as a legal term and citizenship as an idea meaning belonging to a political community. The use of the word citizen for the old (pre-1827) Cherokee is anachronistic. The legal tribal citizenship I am concerned with was a concept that developed alongside the first Cherokee Constitution in the 1820s. Before then, citizenship — better understood as belonging — among the Cherokee depended upon interpersonal relationships within tribe and clan (Littlefield 1978; Sturm 2002; Minges 2003; Smithers 2015). The result of merging an ancestral tradition of hereditary belonging with a US-influenced legal definition of citizenship was a unique arrangement of non-liberal political practices nested legally within a liberal constitutional framework.

In 1827, Cherokee citizenship was reserved for all "descendants of Cherokee men by all free women [and of all Cherokee women by all free men], except the African race...according to the customs and laws of this Nation." ${ }^{21}$ The franchise was extended to all men older than 18 . The Cherokee denied suffrage to women and "members of the African race." 22 The dedication to preserving cultural values and traditional purity was reflected in the restriction of citizenship to those inheriting the Cherokee bloodline. Elected officials were also required to be male and Cherokee by blood. The 1827 Constitution also contained a required religious test to hold public office, reflecting the deep-seeded Cherokee commitment to their spirituality. ${ }^{23}$

\footnotetext{
${ }^{21}$ Elias Boudinot, "Constitution of the Cherokee Nation."

22 Ibid., see Article III, Sections 4-7.

${ }^{23}$ Freedom of religious belief was encouraged, but atheism was strictly prohibited and socially stigmatized. Article VI, Section 2 reads: "No person who denies the being of a God, or a future state of rewards \& punishments shall hold any office in the civil department of this Nation" (Elias Boudinot, "Constitution of the Cherokee Nation," Cherokee Phoenix, 1 no. 1, February 21, 1828).
} 
As the Cherokee developed over time, women and those of African descent were made citizens and extended the franchise — but the commitment to blood citizenship remained (Mankiller and Wallis 1993; Sturm 1998; Edwards 2006). Today, to become a citizen of the Cherokee Nation, one must prove blood relation to someone listed on the Dawes Rolls, a list of residents in Indian Territory compiled by the Congress-sanctioned Dawes Commission in the 1890s and 1900s (Edwards 2006; Sturm 2014). ${ }^{24}$ Chapter four discusses the modern process for becoming a citizen of the Cherokee Nation in more detail within the context of the freedmen's struggle to obtain legal protections from the Cherokee. Suffice to say here that the Cherokee continue to value the concept of hereditary citizenship as an invaluable aspect of their political thought.

\section{Plan of the Dissertation}

Political scientists have not yet produced an analysis of Cherokee political thought or Cherokee tribal citizenship. This absence means that Cherokee political thought has not informed studies of indigenous politics or citizenship. While several scholars have previously referenced Cherokee ethnocentricity (Halliburton 1977; Littlefield 1978; Perdue 1979; Sturm 2014), the inevitable tensions among a multicultural citizenry (Kymlicka 1995; Tully 1995), and even the Cherokee view that society should be oriented toward the public good (Minges 2003; Smithers 2015), these excellent works have been histories or sociological and anthropological studies. A more nuanced view of citizenship, along with the ideas underpinning it, can help produce policies more

\footnotetext{
${ }^{24}$ To prove citizenship through blood ancestry, the Cherokee Nation defers to those individuals and their families listed on the Dawes Rolls, which included people living during the 1898-1907 enrollment period. See Littlefield (1978) for a more detailed look at the Dawes Commission and how US agents categorized Cherokee citizens.
} 
amenable to indigenous populations so that all Americans may find, through an increase in constructive dialogue, a greater stake in the success of the American experiment (Kymlicka 1995; Tully 1995).

I fill in this gap in the literature by creating new interpretive frameworks for studying Cherokee political thought, specifically on the critical issue of citizenship. Ideas matter; they restrain politicians from pursuing certain policies or encourage societies to push for others. My core argument, depicted in Figure 1.1, is that ideological incongruence, along with racial prejudice and acquisitiveness, explain the development of Cherokee citizenship over time. This holistic view of the issue re-contextualizes Cherokee citizenship as a concept not driven solely by the racism or greed of either the Cherokee or US officials, but primarily as an idea contested by ideologically opposed peoples. The actions of both US government officials and Cherokee politicians have played a role in shaping Cherokee citizenship. For example, Cherokee action to define and assert a definition of Cherokee citizenship in accord with the principles of Cherokee political thought has been met with US government action to redefine that citizenship at different points in time.

To support this argument, I position each chapter to view Cherokee citizenship from a different angle. This introduction serves as both roadmap and literature review, to clarify important concepts such as Cherokee political thought, tribal citizenship, and the ancestral political tradition. I present, in chapter two, a thorough analysis of Cherokee political thought and the development of Cherokee citizenship. In chapter three, I offer an analysis and overview of federal Indian policy from 1787-2019 to provide context for the case studies conducted in the subsequent chapter. The fourth chapter offers a case study 
of three American institutions - Congress, the presidency, and the Supreme Court — and how the actors in each have wrestled with the idea of Cherokee citizenship. Chapter five presents an interpretive study of how the Cherokee freedmen-formerly enslaved peoples and their descendants - view tribal citizenship. Chapter six contains both concluding arguments about the nature of citizenship and scholars' solutions to the tension between liberal governments and non-liberal subgroups.

Figure 1.1 Theory of Cherokee Citizenship Development

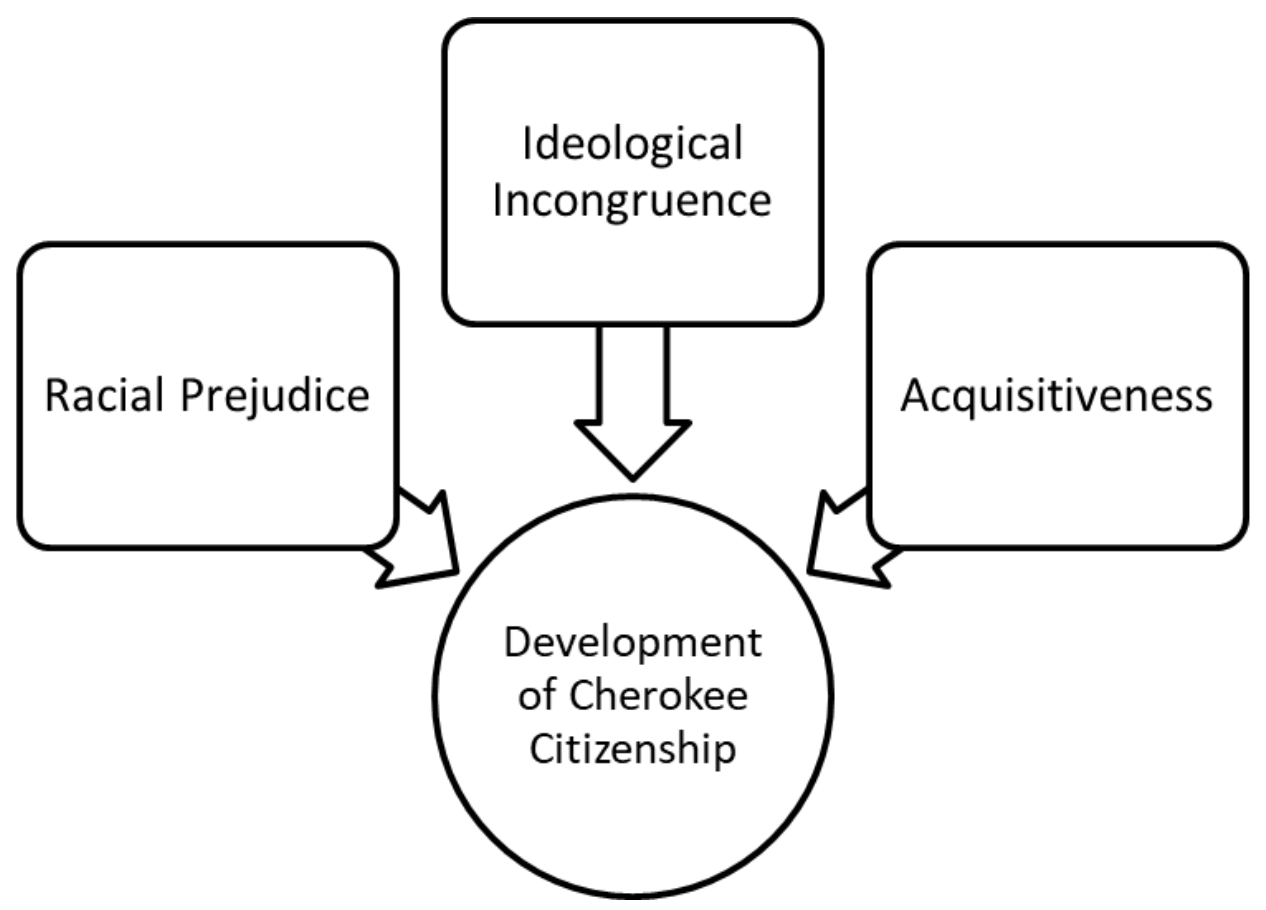

I employ a multifaceted analytical strategy in this project. I establish my work as embedded in the field of American Political Development by creating new interpretive frameworks that may be applied to both American and Cherokee political institutions. In chapter two, I construct a pyramid of foundational and second-story ideas, an analytical tool employed in previous research (Ceaser 2006, 5-6; Rosenblum 2006, 115-117), and use it to identify and interpret the concept of Cherokee political thought. I then bring to bear a search for durable shifts in governing authority, to analyze the development of 
Cherokee citizenship law over time, highlighting the tensions between US and Cherokee policies (Orren and Skowronek 2004, 123). In this chapter, I also use descriptive statistics from an original dataset compiled from Cherokee legislative records to provide context for how the Cherokee National Council has passed legislation pertaining to citizenship over the past forty years.

The first half of chapter two presents the first analysis of Cherokee political thought by constructing a pyramid of foundational and second-story (think second level of a building) ideas that make-up the Cherokee political belief system. In this chapter, I challenge the prevailing academic practice of studying the Cherokee through the lens of American political thought, which renders many Cherokee political customs and practices inane or irrational. The Cherokee-and therefore Cherokee citizenship-are best understood by analyzing their political ideas on their own terms and only then comparing them against American political thought. This new understanding of Cherokee political thought, presented as a theoretical framework, offers greater insight into the ideological incongruence between the Cherokee and the United States.

The second half of chapter two focuses on directly applying the pyramid of Cherokee political thought to study the development of Cherokee citizenship over time. I search for durable shifts in Cherokee citizenship laws, presented as altercations between the Cherokee and the United States over the idea of what being a legal citizen means. To understand Cherokee citizenship, scholars must know what sort of underlying ideas they are dealing with. Those ideas are then useful for charting the development of Cherokee citizenship over time. This chapter implements the first political development study of 
Cherokee government and laws and paves the way for future comparative work, critical for understanding the nature of citizenship.

In chapter three, I create a general federal Indian policy timeline and analyze the implications federal policies had for the Cherokee and how they legally defined citizenship. This analysis provides context to the reader of the general state of federal Indian policy and how the combined efforts of political actors in Congress, the President, and Supreme Court justices resulted in an overarching policy agenda. In chapter four, I approach the subject of Cherokee citizenship from the perspective of the three major United States governing institutions, Congress, the Presidency, and the Supreme Court. Each of the institution sections presents a case study selected from the early $1830 \mathrm{~s}-\mathrm{a}$ critical time in Cherokee history when all three branches of the US government were discussing Cherokee sovereignty simultaneously. In these sections, I analyze critical documents - debates in the Senate, Presidential addresses, and Supreme Court opinions respectively — and interpret whether these publically made arguments not only acknowledged the existence of Cherokee political thought, but also understood the tension between Cherokee and American political thought.

If ideas matter, these institutional case studies should reveal government actors wrestling with the ideological tensions between Cherokee and American political thought in their official arguments. The status of Native Americans has been hotly contested since the Founding. Congress, the Presidency, and the Supreme Court have reacted at various junctures to the state of indigenous peoples in America. The study of institutions and Cherokee citizenship connects the idea of tribal citizenship to the larger American story. In making this connection, and assessing the ideological incongruence between the 
United States and the Cherokee, greater nuance in the American contribution to the concept of citizenship becomes clear.

Chapter five offers a critical analysis of the freedmen's desire for Cherokee citizenship. Using evidence taken from interviews conducted in the 1930s with formerly enslaved peoples, newspaper reports, press conferences, editorials, and modern-day public debates, I piece together the freedmen's arguments for why they want to be Cherokee citizens. These sources offer a well-rounded view of what freedmen leaders and individual lay-members both want and have wanted from the Cherokee government. I break the analysis into two separate time periods (first, from 1866-1907 and second, from 1975-2017) to reflect the historical demarcations offered by the dissolution of the Cherokee Nation in 1907 and its constitutional rebirth in 1975. Using Judith Shklar's (1991) typology of citizenship as a baseline, I find that the freedmen, in the first period, desired citizenship for material benefits and in the second period wanted Cherokee citizenship for both material and ideological reasons. This chapter connects the study of legal tribal citizenship to the deeply personal nature of ancestral belief systems, critical for contextualizing Cherokee citizenship and providing human perspective.

This dissertation is a work of political science and therefore is presented as a search for causal mechanisms and theoretical justifications for them. It is not, as most studies of the Cherokee have been, a history. Many detailed historical facts, while interesting or important in their own right, have been omitted; other works have covered them. Historical facts or anecdotes are presented in the following pages when they are useful for explaining where ideas of citizenship came from and how those ideas developed over time. Identifying causal mechanisms in the development of Cherokee 
Nation citizenship will aid scholars in conceptualizing the American contribution to the concept of citizenship, how the US has influenced subordinated nations, and how diverse views of citizenship are within America itself.

\section{A Clash of Ideas}

In October 2018, Senator Elizabeth Warren (D-MA) released the results of a DNA test she had undergone to prove that she possessed Native American-Cherokee and Delaware-ancestry. ${ }^{25}$ The move was prompted by a series of verbal altercations between the Senator and President Trump over the legitimacy of Sen. Warren's claims. Critical responses to the DNA test results - which concluded that Sen. Warren likely had a Native American ancestor 6-10 generations prior-were negative. ${ }^{26}$ Some Democratic Warren supporters were perplexed by the move, while Republican opponents were quick to cast Warren as insensitive to indigenous peoples. ${ }^{27}$ Shortly after, Cherokee Secretary of State, Chuck Hoskin Jr., issued a statement condemning the use of DNA tests to establish citizenship with tribal governments, arguing that "Senator Warren is undermining tribal interests with her continued claims of tribal heritage." 28 While Sen. Warren officially apologized to the Cherokee Nation in February 2019, the incident made

${ }^{25}$ Asma Khalid. "Warren Releases DNA results, Challenges Trump Over Native American Ancestry," NPR, October 15, 2018, https://www.npr.org/2018/10/15/657468655/warren-releases-dnaresults-challenges-trump-over-native-american-ancestry (accessed May 20, 2019).

26 Ibid.

${ }^{27}$ Chris Cillizza. "Elizabeth Warren Might Have Actually Made Things Worse with Her DNA Gambit," CNN Politics, October 17, 2018, https://www.cnn.com/2018/10/16/politics/elizabeth-warrendonald-trump-pocahontas/index.html (accessed May 20, 2019).

28 “Cherokee Nation Responds to Senator Warren's DNA Test," Cherokee Nation Secretary of State Chuck Hoskin Jr., accessed February 4, 2019, https://cherokee.org/News/Stories/Archive 2018/20181015 Cherokee-Nation-responds-to-SenatorWarrens-DNA-test. 
salient a centuries-old tension between the United States and indigenous peoples — what does it mean to be a tribal citizen and who gets to decide ${ }^{29}$

Citizenship for the Cherokee, as the confusion over Sen. Warren's DNA test illustrates, means something different than US citizenship. This dissertation focuses on interpreting, analyzing, and understanding the nature of that difference. For many Americans, the liberal conception of the state as an association of rights-bearing free agents who contract with one another for peace and happiness is often taken for granted (Collins 2006, 2). While the liberal tradition is a contested topic (Morgan 1975; Hartz 1991; Smith 1997; Dyer 2012), the liberal conception of citizenship is, generally speaking, a contract granting equal legal status to non-related individuals. This view of citizenship is distant from that espoused by groups grounded in non-liberal ancestral traditions. The Cherokee conception of citizenship is communal and deeply personal. The stakes are high for those seeking US citizenship, but in many ways the stakes are even higher for the Cherokee, who see legally belonging to the tribal community as something intrinsically humanizing and spiritual (Wax and Wax 1978; French 2016).

For this project, I selected the Cherokee for two reasons. First, the Cherokee are and historically have been among the largest indigenous tribes in America. This means that the interactions between the Cherokee and United States over time have created a space for more conflict between liberal and ancestral traditions. Furthermore, the availability of primary documents and other data make the Cherokee an attractive choice to explore my question. Second, I had the opportunity to meet with Kimberly Teehee,

\footnotetext{
${ }^{29}$ Asma Khalid. "Warren Apologizes to Cherokee Nation for DNA Test," NPR, February 1, 2019, https://www.npr.org/2019/02/01/690806434/warren-apologizes-to-cherokee-nation-for-dna-test (accessed May 20, 2019); Maggie Astor. "Why Many Native Americans Are Angry with Elizabeth Warren," The New York Times, October 17, 2018, https://www.nytimes.com/2018/10/17/us/politics/elizabethwarren-dna-test.html (accessed May 20, 2019).
} 
Director of Government Relations for the Cherokee Nation, during her 2017 visit to the University of Missouri. That conversation first made me question the relationship between the United States and tribal governments. Specifically, while she spoke about the supplicant status of the Cherokee, I was driven to learn how that status came to be and what role their ancestral political tradition played in that development.

This project fills a gap in the political science literature by creating theoretical frameworks useful for studying indigenous governments, with respect to how they define citizenship, within the United States. While previous research has primarily focused on the evolution of US law and how court decisions have affected the Cherokee (Edwards 2006; Duthu 2008; Perdue 2016), political scientists have thus far not produced research assessing the interaction of all three American federal institutions over the issue of Cherokee citizenship. Chapter two adds to the growing field of American political development by creating and implementing a new theoretical framework for how scholars may analyze the development of tribal citizenship laws. Chapter three of this dissertation adds to the conversation an analysis of how Congress, the Presidency, and the Supreme Court have combined to shape Cherokee citizenship by interpreting how US political actors have dealt with Cherokee political thought. The fourth chapter speaks to scholars of American political thought and suggests new ways for interpreting how marginalized populations within indigenous governments understand the concept of tribal citizenship and the tensions between American and Cherokee political thought.

The goal of this project overall is to produce an understanding of citizenship as crafted by Cherokee political thought. The benefits of such an understanding are many. We may, by approaching tribal citizenship, not from an American liberal lens but from an 
appreciation of the unique political tradition that inspired it, increase productive dialogue across governments and give lawmakers the opportunity to create policy truly beneficial to all Americans (Kymlicka 1995; Tully 1995). A new approach to how we think about tribal citizenship may also alter how future research in American political thought and development is conducted going forward.

Understanding the nature of Cherokee citizenship is important for three main reasons. First, American political thought has been shaped over time by a struggle between liberal and non-liberal ideologies (Kettner 1978; Smith 1997). The development of Cherokee citizenship, grounded in a fundamentally non-liberal political tradition, helps us better understand how ideas have clashed to forge American political thought and the liberal notion of citizenship. Second, many groups in the United States hail from nonliberal ancestral traditions (Sturm 2014); reconciling tensions between these political communities and the US, and the creation of constructive policies, requires a proper understanding of indigenous politics. Third, the meaning of citizenship — what it means to be a citizen - is currently salient and disputed in American political discourse (Collins 2006; Sides et al. 2018). Since citizenship grants access to government programs and communal acceptance, the knowledge of what drives indigenous communities to identify as political equals carries immense political weight. If people do not feel connected to their government, the resulting alienation may lead, as it has all too frequently, toward social unrest. 


\section{Chapter 2: Cherokee Political Thought}

Upon election in 1975, Principal Chief Ross Swimmer immediately fought for the ratification of a new Cherokee Constitution, a document that officially signaled the rebirth of Cherokee self-governance after seventy years of direct US federal oversight (Mankiller and Wallis 1993, 217-218). The new constitution was meant to bring unity to a people long-bereft of a solid governing identity. Reactions to the document were, however, from the perspective of Wilma Mankiller, who would succeed Swimmer as Principal Chief, far from unified (Mankiller and Wallis 1993, 218-219). The Cherokee were especially divided over the constitutional provisions made for tribal citizenship. "Many people thought a requirement of one-quarter blood quantum should have been instituted," while others alternately "objected to the inclusion of the Delawares and Shawnees" or the "exclusion of the Cherokee freedmen and intermarried whites" (Mankiller and Wallis 1993, 218). Division over who counts as Cherokee was not new in the 1970s. Such division came from years of struggling against the United States over Cherokee sovereignty and identity. This struggle continues today.

In the United States, the concept of tribal citizenship is often mystifying and internal Cherokee political debates over citizenship are obscured by an American misunderstanding of the issue. ${ }^{30}$ There are three main reasons for general American confusion over Cherokee citizenship. The first reason for the confusion is the fact that US

${ }^{30}$ Gregory D. Smithers, "Why Do So Many Americans Think They Have Cherokee Blood?” Slate, October 1, 2015, https://slate.com/news-and-politics/2015/10/cherokee-blood-why-do-so-manyamericans-believe-they-have-cherokee-ancestry.html (accessed June 4, 2019); Fiza Pirani, "Native Americans, Cherokee Nation react to Elizabeth Warren's DNA test," Springfield News-Sun, October 16, 2018, https://www.springfieldnewssun.com/news/national/native-americans-cherokee-nation-reactelizabeth-warren-dna-test/xy3YskJcU4Ox1ygxaWfM6J/ (accessed June 4, 2019) 
officials, and the Cherokee themselves in reaction to those officials, have periodically changed the legal definition of tribal citizenship. Second, racial prejudice and material acquisitiveness have also cultivated a distance between Cherokee and American culture (Sturm 1998; Tocqueville 2000; Smithers 2015). Finally, the tension between American and Cherokee political thought has prevented many Americans from understanding the nature of Cherokee citizenship, its importance, and the lessons its development has for scholars who study citizenship. These three reasons have created an atmosphere of unease when discussing Native American heritage and tribal citizenship, as shown in the case of Sen. Elizabeth Warren, who seemed genuinely caught off guard by the negative Cherokee reaction to her claim of blood ancestry. ${ }^{31}$

Applying the analytical strategies of American Political Development (APD) to the study of Cherokee politics clarifies the concept of Cherokee citizenship. Political development, the study of ideas and how they translate into political reality, can help scholars understand the pyramid of ideas underpinning Cherokee political thought. ${ }^{32}$ Ideas do not remain in a vacuum, they "are adopted, adapted, and used in politics by thoughtful" and sometimes "thoughtless political actors" (Rosenblum 2006, 115). The way political actors translate ideas into policy affects real human lives. The lack of any political development studies on the Cherokee government presents a unique opportunity

${ }^{31}$ Rob Capriccioso, "Cherokee Women Try to Meet with Elizabeth Warren; Campaign Offends Them," Indian Country Today, June 21, 2012, https://newsmaven.io/indiancountrytoday/archive/cherokee-women-try-to-meet-with-elizabeth-warrencampaign-offends-them-4ADmHzb3iEiYH8EWFx92kQ/ (accessed June 4, 2019); Grant D. Crawford, “Cherokee Citizenship Determined by Dawes Rolls, not DNA," Tahlequah Daily Press, November 2, 2018, https://www.tahlequahdailypress.com/news/local news/cherokee-citizenship-determined-by-dawesrolls-not-dna/article 4a41fca2-3b65-5413-837c-9fcdf99efa7a.html (accessed June 4, 2019).

32 This is a contested claim among APD scholars. Some posit that ideas matter for studying the development of American political systems and practices (Ceaser 2006; Rosenblum 2006; Dow 2017). Other scholars focus not so much on ideas but on how American political institutions evolved via adaptive decision-making and shifts in governing authority (Orren and Skowronek 2004; Squire 2012). 
to identify foundational and second-story ideas underlining Cherokee political thought and see how the idea of citizenship has evolved over time.

I contribute to the ongoing discussion of political development by creating a new theoretical framework for interpreting and analyzing the idea of Cherokee citizenship. The framework is presented as a pyramid construction of Cherokee political thought, including both "foundational" and "second-story" ideas (Rosenblum 2006, 116). These concepts, explored more thoroughly in the following sections, represent different kinds of ideas. Through this framework, I show how tribal citizenship has been shaped by two dynamic processes - by a struggle against the United States to assert Cherokee sovereignty and by Cherokee efforts to forge, affirm, and maintain a cultural identity. ${ }^{33}$ The presentation of Cherokee political thought offered here reveals not only why and how Cherokee citizenship has changed, but also why and how it has remained the same.

The value of this study lies in how it aids in understanding the citizenship laws that have shaped the lives of so many indigenous peoples in the United States. America extends its influence over both unincorporated territories, such as American Samoa or Puerto Rico, and indigenous nations, like the Cherokee, Creek, or Seminole. These subgovernments and their peoples have all been influenced by both American political thought and their own non-liberal political traditions (Bailey 1972; Erman 2018; Kruse 2018). For a more complete picture of citizenship in America, we need to consider how these peoples understand citizenship. As America expands and diversifies, alternate

\footnotetext{
${ }^{33}$ These processes remain an integral part of Cherokee public discourse and represent an ongoing point of contention in Cherokee politics (Staff Reports, "Cherokee Nation and Freedmen: A Historical Timeline," The Cherokee Phoenix, September 27, 2017; Jason Tarrell, "Editorial from a Member," Cherokee Observer, April 1996). The Cherokee Phoenix and the Cherokee Observer each contain many references and special articles dedicated to issues of Cherokee sovereignty, identity, and citizenship for the freedmen, especially over the last three decades.
} 
views of citizenship will increase in political relevance. Understanding why certain laws exist, like those written in the 1975 Cherokee Constitution, and where they came from is crucial for cultivating political engagement, productive discourse, and humanizing policies.

\section{Cherokee Political Development}

Ideas have consequences. But while all ideas may have consequences, there are different types of ideas. Some ideas may be classified as "foundational concepts" at the base of a pyramid (Ceaser 2006, 5). These ideas are manifested in political discourse as the ultimate justification for political positions or policies. Foundational concepts help political leaders, and scholars, answer the question "Why." Further up the pyramid are second-story ideas, concepts that help scholars move from answering "Why" to answering "How" concepts "are encountered as tangible political phenomena in the practical political world" (Rosenblum 2006, 116). This strategy aids the analyst in first organizing ideas into defined packages that may then change over time. I apply this strategy to the study of Cherokee political thought. ${ }^{34}$

Other scholars have argued that the primary interest of APD is in "grasping processes of change conceptually" and "considering their broader implications for the polity as a whole" (Orren and Skowronek 2004, 6). A political development is "a durable shift in governing authority," where "authority" means the exercise of control over persons by the state and "shift" means a change in the "locus of direction of that control"

\footnotetext{
${ }^{34}$ An argument can be made claiming that Cherokee political thought is actually American political thought, since the Cherokee are, in fact, Americans. I keep the two separate so as not to confuse the reader and to illustrate the fundamental differences between American and Cherokee political ideas. Cherokee political thought takes some inspiration from American political thought, yet remains distinct from it.
} 
(Orren and Skowronek 2004, 123). Here, the "analyst jumps in and investigates major ideas" as they appear in time and forms their political-analytical inquiry from that starting point (Ceaser 2006, 13). Yet even in this context, adaptive decision-making, which leads to durable shifts in governing authority, takes place within an environment shaped by certain political ideas. I use this strategy — the search for durable shifts—-grounded in the pyramid of ideas underpinning Cherokee political thought, to analyze the development of the idea of Cherokee citizenship and demonstrate both why and how it has changed.

Defining Cherokee political thought presents an interesting challenge. On the one hand, traditional Cherokee mores and practices often defy concrete definition, at least in the way that American scholars may consider them (Smithers 2015).${ }^{35}$ On the other hand, Cherokee politics, at least since the $19^{\text {th }}$ Century, has been so intertwined with American politics that parsing out unique Cherokee innovations is difficult. The basic framework of Cherokee political thought is elements of an ancestral tradition supplemented by certain ideas derived from American politics. I draw from historic texts, legal documents, and Cherokee writings to interpret Cherokee political thought and construct a pyramid of foundational and second-story ideas.

\section{Constructing a Pyramid of Cherokee Political Thought}

I begin my analysis and assessment of Cherokee political thought with the creation of the 1827 Constitution. There is, of course, a rich history of Cherokee politics before 1827 and historians may lament my decision, however, the development of Cherokee citizenship — in its current form that designates legal membership — began in

\footnotetext{
${ }^{35}$ These Cherokee mores and practices refer to the Cherokee ancestral tradition, a concept dealt with more thoroughly in the introduction. See pages 7-11 of this dissertation for a detailed examination of the ancestral tradition.
} 
1827. That constitution reveals both second-story and foundational ideas. The secondstory ideas, ideas that tell how foundational ideas translate into political reality, are reflected in the laws and the design of the constitution itself. The foundational ideas, however, are implicit in the constitution and require deeper analysis. In order to "get our knowledge of simple things from composite things," I begin by analyzing the 1827 Constitution to gather what sort of second-story ideas are immediately present (Aquinas 1968, 29).

In order to better situate themselves politically, in the hope that the United States government, and the state of Georgia, might take them more seriously as a sovereign nation, the Cherokee held a constitutional convention in the summer of 1827 (McLoughlin 1986, 388-389). ${ }^{36}$ The Cherokee opted to create a government with separated legislative, executive, and judicial powers that emphasized the protection of the enumerated individual rights held by Cherokee citizens. The educated mixed-blooded elite among the Cherokee found much to praise in the form of the United States Constitution and adapted it to suit their own purposes (McLoughlin 1986, 388, 450). On the surface, these two constitutional documents seem similar.

A closer reading of the 1827 Constitution, however, reveals several distinct differences from the United States in how the Cherokee intended their government to function. First, and perhaps most importantly, the Cherokee sought to protect their ancestral homelands from hostile takeover (Moulton 1985, 35-36; Smithers 2015, 22-23). Article I of the 1827 Constitution explicitly states that Cherokee lands are theirs, to

${ }^{36}$ Elias Boudinot, "Constitution of the Cherokee Nation," The Cherokee Phoenix, 1 no. 1, February 1828. 
"remain the common property of the Nation," in perpetuity. ${ }^{37}$ The lands they referred to in 1827 were, of course, those in modern day Tennessee, North Carolina, Alabama, and Georgia - lands they would soon be driven out of under the Jackson and Van Buren Administrations. The commitment to common land ownership, however, remained and appeared just as prominently in the 1839 Constitution, formed after Removal.

Citizenship in this constitution was also defined differently from the United States' legal definition. Article III, section 4 states that "the descendants of Cherokee men by all free women, except the African race... as well as the posterity of Cherokee women by all free men...shall be entitled to all the rights and privileges" of the Cherokee Nation. ${ }^{38}$ Section 7 further qualified that voting rights were to be extended to "all free male citizens... who shall have attained to the age of eighteen years." ${ }^{39}$ Women, children, and blacks were not given the franchise, much like the legal practice in the United States at the time (Kettner 1978). Citizenship then was restricted to blood Cherokee.

Another striking difference between the first Cherokee Constitution and the US Constitution is the amount of power given to the government, especially the General Council. The Cherokee Supreme Court was to have three justices who were appointed by the National Council to finite terms. ${ }^{40}$ The General Council was their bicameral legislature-representatives were selected from multimember districts for brief terms, one to two years depending on the upper or lower house. The General Council was responsible for electing the Principal Chief, according to Article IV, Section $1 .{ }^{41}$ The 1827 Cherokee Constitution set up a government that relied heavily on the General

\footnotetext{
${ }^{37}$ Boudinot, "Constitution of the Cherokee Nation."

38 Ibid.

39 Ibid.

40 Ibid, Article V, Section 5.

${ }^{41}$ Boudinot, "Constitution of the Cherokee Nation."
} 
Council, the members of which were responsible for selecting the officials in the other two branches. This style of trustee representation is consistent with republican government. The form of government outlined in this constitution is a kind of ethnic republicanism - a society whose membership is restricted to blood relatives, dedicated to pursuing the public good.

Cherokee citizens were afforded similar legal rights to those listed in the US Constitution. Article V, Sections 14 and 15 state that citizens shall have a right to what Americans might also consider a fair trial and the right to be "secure in their persons, houses, papers, and possessions from unreasonable searches and seizures." ${ }^{42}$ Where enumerated rights differed most is in the relationship between church and state. Article VI, Section 1 prohibits preachers or any ministers of the Gospel from holding office while also performing pastoral functions, yet Article VI, Section 2 prescribes a religious test to hold office, stating that "no person who denies the being of a God, or a future state of rewards \& punishments shall hold any office in the civil department of this Nation." ${ }^{43}$ Article VI, Section 10 reinforces this religious test to hold office by proclaiming that "religion, morality, and knowledge" are essential to good government, the "preservation of liberty, and the happiness of mankind." ${ }^{44}$ The Constitution also guaranteed the Cherokee the freedom of religious belief and practice, a "liberty of conscious." 45

The 1827 Constitution reveals several second-story ideas - ideas about how the Cherokee thought that their government should function. Land should be held in common. Citizenship should be reserved for those related to the Cherokee people by

\footnotetext{
${ }^{42}$ Ibid.

${ }^{43} \mathrm{lbid}$.

${ }^{44} \mathrm{Ibid}$.

${ }^{45}$ Ibid, Article VI, Section 3.
} 
blood. Free blacks should be excluded from citizenship because of their race. The individual rights held by citizens should be protected by the government. Religious belief should be promoted and protected by the state. Atheists should be barred from public service. The General Council should hold most of the political power in the government. Representatives, some directly elected but many appointed, should make critical decisions for the public good. Each of these composite ideas reflects the influence of some foundational idea. In the next section, I analyze each of these second-story ideas to arrive at foundational ideas that form the basis of Cherokee political thought.

\section{Foundational Ideas in Cherokee Political Thought}

The second-story ideas presented in the 1827 Cherokee Constitution reflect concepts drawn from both the ancestral and liberal political traditions. In the previous chapter, I outlined the Cherokee ancestral political tradition, where many of the foundational ideas implicit in the 1827 Constitution come from. According to the Cherokee ancestral tradition, the earth exists in a precarious balance, right actions keep life orderly whereas wrong actions upset mortal harmony (Wax and Wax 1978, 28-30). The way the ancient Cherokee lived, in loosely organized towns, dependent upon communal action and familial relationships for survival, was intended to keep life balanced (Smithers 2015). Kinship associations and clan affiliation largely determined the role that each individual would play in the community; having a Cherokee mother was key to Cherokee identity (Sturm 2002, 28). Cherokee towns were loosely organized, structured to facilitate natural spiritual flourishing by allowing Cherokee to freely interact with one another and the land. 
The Cherokee people were profoundly spiritual. They "led a life full of ritual, ceremony, myth, and symbol...life was hedged with spiritual significance in every respect. All dreams were important omens” (McLoughlin 1986, 14-15). Blood was a "central metaphor for life" (Sturm 2002, 35). One of the most sacred stories in Cherokee mythology, the story of Selu and Kanati, presents a "cautionary tale about the power of blood" (Hill 1997, 77). Selu is cruel because she wastes blood by discarding living matter-the moral of the story was to "shed blood with care" because blood is life (Hill 1997, 77). When Selu is later killed by her children, her blood brings forth corn from the earth (Mooney 1900, 244-245). Her blood became a metaphorical source of Cherokee life (Sturm 2002, 35). Those red human beings - the first men and women - came to be called Aniyunwiya, the real people (Mankiller and Wallis 1993, 16).

Cherokee culture was grounded in the land and nature in a way utterly foreign to individuals versed solely in the American liberal lexicon (Mankiller and Wallis 1993; Smithers 2015). ${ }^{46}$ The Cherokee had "a nuanced, layered understanding of the word 'home,' and they defined it in a collective sense,' one that indicated a permanent place of settlement, "collectively owned land" (Stremlau 2011, 95). Cherokee beliefs "imposed a rigid personal morality and an intense communal ethic" that integrated their lives in a meaningful, clear, cohesive order (McLoughlin 1986, 14). Personal duties toward nature included performing regular festivals and rites linked to the agricultural seasons and ritualistic daily prayer (McLoughlin 1986, 15). Human beings, the land, nature, and the spirit world were all closely intertwined. The purpose of living was to produce

46 "Common [land] ownership was also advantageous to the planter and herdsman," according to one historian (Halliburton 1977, 20). 
harmony - the Cherokee, the real people, achieved this goal by respecting the sanctity of everyday life, community, the earth, and themselves.

The legal commitment to communally held lands in the 1827 Constitution stemmed directly from the belief in the sacredness of nature and the role the Cherokee played communing with the spirit world. The foundational ideas underpinning the idea that land should be held in common are the principles of harmony and balance. These critical principles formed the Cherokee belief in the relationship between man and nature. Land could not be owned by an individual. The community was responsible for performing the sacred rituals that kept the earth balanced and the people alive. From a young age, Cherokee children were taught that "self-interest should give way to the will of the community" (McLoughlin 1986, 12). The Cherokee placed great emphasis on group consensus and "not on individual competition" (French 2016, 8). The decision to hold lands in common is therefore rationally derived from the principles of harmony and balance.

In a similar vein, the Cherokee idea of blood citizenship was derived from the idea that the Cherokee were the real people. "There is an old Cherokee prophecy," wrote Chief Mankiller, "which instructs us that as long as the Cherokee continue traditional dances, the world with remain as it is, but when the dances stop, the world will come to an end" (Mankiller and Wallis 1993, 29). Chief Mankiller's words reflected a belief in the integral importance of the Cherokee people to the world order. The community was so important to the Cherokee-family, clan, and town were essential to Cherokee spirituality - that the Cherokee people took the exclusion of non-Cherokees from tribal 
membership for granted (Halliburton 1977; Sturm 2002). Blood membership, a practice that had existed for centuries, therefore became codified in the law in 1827.

The Cherokee spirituality explains the inclusion of religious tests for office, the dedication to promote religious belief and morality, and the right to religious practice in the 1827 Constitution. Since the Cherokee belief system permeated all corners of Cherokee life, the framers of the 1827 Constitution naturally wrote that governing document with an eye to the cultivation and protection of spiritual belief. The 1827 Constitution, however, while adamant about the importance of religious belief, is vague on the type of belief. William McLoughlin argued that the infusion of Christianity into the Cherokee Nation — most of the 1827 Constitution's framers were mixed-blooded, educated Christians — resulted in Cherokee political leaders scaling back a number of ancient Cherokee practices in favor of Christian morality (1986, 388-389). ${ }^{47}$ The conversion to Christianity, rather than tempering Cherokee spirituality, seems to have flowed harmoniously with pre-existing Cherokee beliefs (i.e., the life-giving power of blood, the Holy Spirit, the importance of prayer and penance). The influx of Christian missionaries, and the increasing number of mixed-blooded members, did not dim the Cherokee zeal for worship (Prucha 1976; McLoughlin 1986, 356-362).

Scrupulous readers will note that the Cherokee Constitution contained a "right" to the free exercise of religion and that similar rights language is contained in the US Constitution. ${ }^{48}$ The use of rights language in the Cherokee Constitution was the result of years of intermingling with American culture. Over time, a potent division between

\footnotetext{
47 "The most offensive laws [to Cherokee dissidents] may have been those undermining old customs (clan revenge, matrilineal inheritance, witchcraft, polygamy, infanticide) and imposing Christian morality (opposing gambling, promoting Sabbath observance, prohibiting ardent spirits)" (McLoughlin 1986, 389).

${ }^{48}$ Boudinot, "Constitution of the Cherokee Nation."
} 
traditional, full-blood Cherokee and mixed-blood Cherokee arose. "Well-to-do, English speaking [and English educated] mixed-bloods," like John Ross (Moulton 1985, 34-36), had gained control of the Cherokee government and were largely responsible for the drafting of the Constitution (McLoughlin 1986, 394). These Cherokee political leaders saw the value in appropriating rights language from the United States so that the Cherokee might meet American government officials on an equal footing. The foundational idea that human beings possess individual rights, therefore, stemmed from the experiences of Cherokee elites, who used such language to legally justify Cherokee interests in a way that white civilization could understand.

Finally, the idea of a constitutional government emanated from a combination of different foundational ideas (e.g., human beings are communal and possess individual rights, principles of harmony and balance govern all human and spiritual activity, etc.). The Cherokee in the 1820s were faced with a daunting decision between modernizing their government structure to more effectively interact with the United States or perishing at the hands of white settlers and dismissive American officials. Political necessity demanded a unified government (Conley 2005); political prudence recommended that the Cherokee follow the United States' example in crafting that unified government. Through the new Constitution, the Cherokee displayed a commitment to the rule of law, by which, they thought, they could protect their rights as human beings to live, worship, labor, and thrive as they saw fit. The summation of these concepts, foundational and second-story ideas, are shown in Figure 2.1.

Figure 2.1 displays a pyramid of ideas comprising Cherokee political thought. Second-story ideas are shown on the second level, as in a building, and answer "how" 
foundational ideas are practiced in the real world. How is the communal nature of human beings, with respect to the harmony and balance that exist between man and nature, manifested as political reality? The answer to that question is "communally held lands." Foundational ideas rest on the bottom. These ideas help answer the question "why." For example, why did the Cherokee restrict legal citizenship to those with only Cherokee blood? The answer to this question is because the Cherokee, the real people, believed that they had a special role to play in keeping the earth balanced. Again, the purpose of this theoretical framework is to help outline my inquiry into the nature of Cherokee citizenship, how and why it has changed and how and why it has remained the same over time.

\section{Figure 2.1: A Pyramid of Cherokee Political Thought}

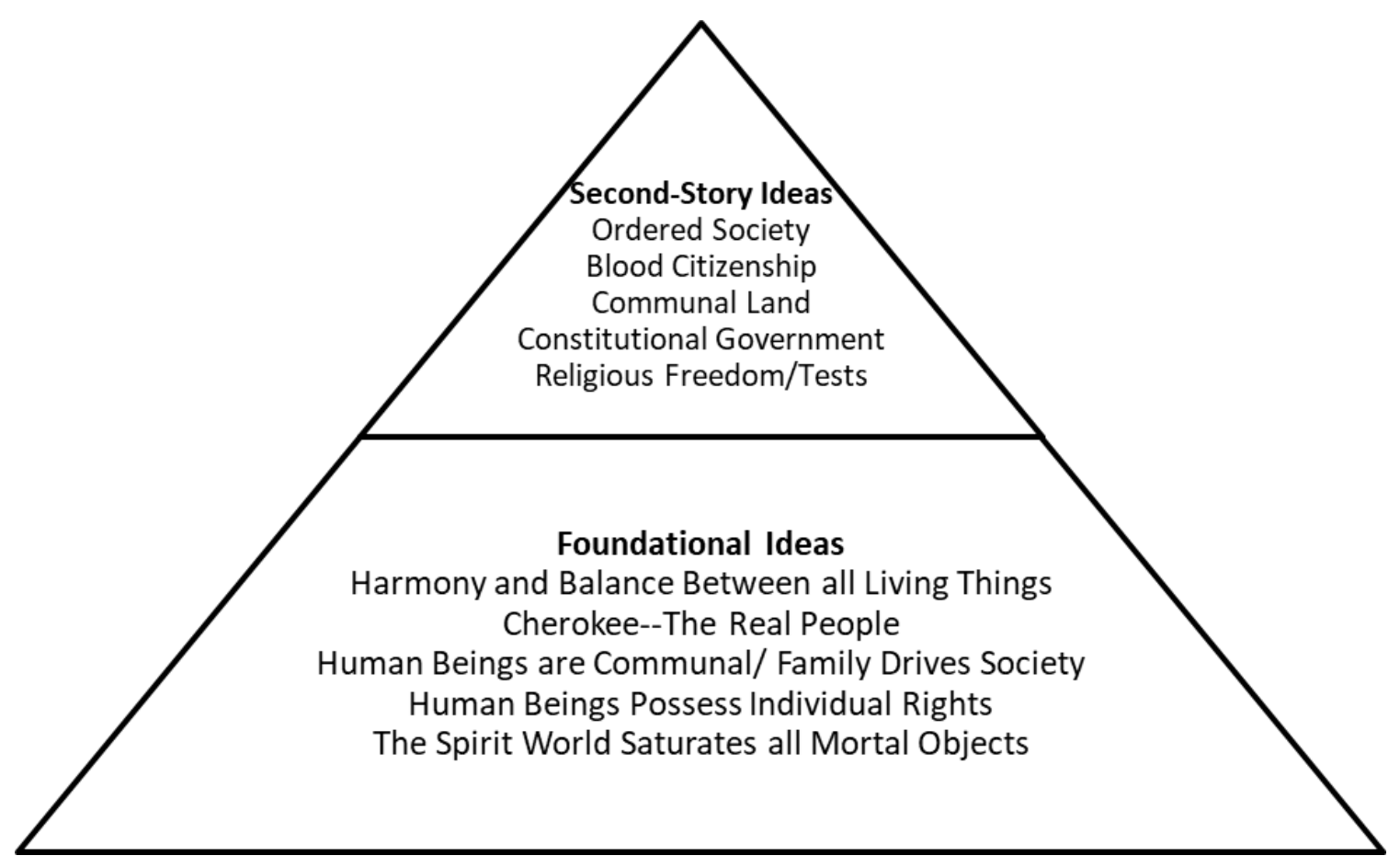


The pyramid of Cherokee political thought, taken in totality, suggests that the Cherokee desired an ethnic-republican form of government. ${ }^{49}$ By ethnic, I mean that the Cherokee sought a government dedicated to the specific protection of the Cherokee people. By republican, I mean that the Cherokee desired a government dedicated to pursuing the public good - harmony and balance in the world - that could only be achieved by the Cherokee adhering to certain ancient customs. These ancient customs, however, were meshed with specific rights language adopted from legal experiences with white civilization. The Cherokee used the United States' constitutional framework to protect Cherokee interests. An integral component of Cherokee political thought was the requirement that all citizens be related to the tribe by blood. In the next section, I explore the development of Cherokee citizenship overtime, searching for durable shifts in governing authority.

\section{Searching for Durable Shifts in the Development of Cherokee Citizenship}

The two goals of this chapter, as stated above, are to create a theoretical

framework from which to discuss Cherokee political thought and to identify, analyze, and

${ }^{49}$ Cherokee political thought may more accurately be compared to republicanism than liberalism. The Cherokee community was traditionally one ordered toward the public good; in their case that meant the maintenance of the precious "harmony and balance" between all life on earth (Mankiller and Wallis 1993, ix). Individuals, families, and clans held specific societal roles intended to balance the world (Littlefield 1978; Mankiller and Wallis 1993). Lands were held in common for that same good end (Stremlau 2011; Smithers 2015). Deliberation on the public good, as occurs in a republican form of government, for the Cherokee was focused on the maintenance, or attainment, of traditions already understood to lead men to a state of harmony - the Cherokee "Old Ways" (Awiakta 1993).

Given the Cherokee commitments to harmony and balance-made manifest in their legal demarcations of citizenship, land ownership, and individual rights - I define Cherokee political thought as an ethnically centered form of republicanism. The government created by the 1827 Constitution, while designed to place ultimate sovereignty in the hands of the citizenry, relied heavily on officials appointed by direct representatives to make many important decisions. The 1827 Constitution was also imbued with the sense that the public good is best maintained by protection of sacred traditions - specifically through the protection of communal land ownership and the mandate of blood citizenship. 
interpret durable shifts in the evolution of Cherokee citizenship. In the previous section, I created a new framework, an idea pyramid simplifying the package of ideas I term Cherokee political thought. In this section, I focus on how and why Cherokee citizenship has or has not remained the same over time. Cherokee political thought, of course, did not exist in a vacuum either. For the purposes of this piece, however, I concentrate on the changes undergone in the concept of Cherokee citizenship - again, citizenship for the Cherokee is derived from foundational ideas in Cherokee political thought. Therefore, changes to Cherokee citizenship, made by the Cherokee, will involve debates over foundational ideas.

Given the Cherokee commitment to their ancestral political tradition, I expect that Cherokee tribal citizenship laws will change following altercations with the United States over either issues of sovereignty or identity. By altercation, I mean an attempt by US officials to alter some aspect of Cherokee political thought and bring it more into conformity with American political thought. I define issues of sovereignty as those issues affecting the Cherokee ability to self-govern as a sovereign nation. Issues of identity are those affecting Cherokee cultural traditions or ancestral politics more directly. These concepts are not always mutually exclusive. Starting with the creation of the 1827 Constitution, I begin searching for significant changes to Cherokee citizenship law.

\section{Cherokee Citizenship, 1827-1866}

The Cherokee were removed from their homelands during the late 1830s (Purdue 2016). Entire families with as many of their possessions as they could carry were forced to march across the United States - thanks in part to the enforcement of the Treaty of 
New Echota, the validity of which was tenuous at best. ${ }^{50}$ Once established in what would become Oklahoma, however, the Cherokee reaffirmed their governing authority by successfully hosting a second constitutional convention. The Cherokee Constitution of 1839 generally reiterates the points made in the 1827 Constitution, with a few notable additions.

Citizenship in the 1839 Constitution was defined as belonging to the descendants of Cherokee men or Cherokee women by all other free men or women except those of African descent. Provisions were made in 1839 for marrying into the Cherokee Nation to become a citizen as well — any male citizen of the United States could obtain a license from the Cherokee Nation to become a citizen, through marriage, of the Nation. ${ }^{51}$ Otherwise, citizenship flowed through the Cherokee bloodline, excluding those of African descent. Cherokee citizens did not have the right to harm the community. ${ }^{52}$ Put another way, the right of the land to remain intact, held communally under the sole control of the Cherokee Nation, shall not be infringed. The general rights and privileges of Cherokee citizenship were, however, left undefined save for the right to trial and representation. An official statement released by the convention reaffirmed the Cherokee as a "separate and distinct nation" in possession of the "essential and appropriate

50 The Treaty of New Echota-signed December 29, 1835-was signed at a conference held by one Reverend John Schermerhorn, who preached to a clearly biased, partisan crowd in favor of removal, a clear minority among Cherokee. This document became known as The Christmas Trick. Chief Ross, who was in Washington at the time, believed that the US government would never accept such a document. But pro-treaty Cherokee, John Ridge and Stand Watie, came to Washington themselves as part of a rival Cherokee delegation, carrying with them the new treaty. The new treaty gave up Cherokee lands for $\$ 5$ million and, in exchange, the Cherokee got new western borders west of the Mississippi (Moulton 1985, 7-8).

51 Ibid. An Act to legalize marriage with white men-passed on September 23, 1839.

52 In 1839, the term "right" is explicitly used in Article I, Section 2 in the sense that individual Cherokee do not have the right to harm the community by giving lands or property to the United States. 
attributes of sovereignty" since time immemorial. ${ }^{53}$ The statement also defended "each individual in the enjoyment of all his rights" and suggested that their "original and inalienable rights" were the basis for the new governing constitution. ${ }^{54}$

Throughout the 1840s and 50s, as the Cherokee settled into their new territory, the Nation found itself changing demographically. Racial tension slowly emerged as the "mixed blood" population grew and the number of "full blood" Cherokee shrank (Littlefield 1978, 7-10). According to Littlefield, to be a full blood Cherokee meant something more than simply racial pride — being a full blood meant standing up for traditional Cherokee values and resisting the impositions of white civilization $(1978,8)$. The full-blooded Cherokee also generally did not own slaves and were largely turned off to the practice (Littlefield 1978, 8-9). The slave-owners among the Cherokee, who collectively owned more slaves than any other Indian Nation, tended to be those with mixed ancestry for whom the practice had been beneficial as well as part of their family heritage (Littlefield 1978).

The Cherokee Nation, amid their own infighting, was swept up into the Civil War, partially due to their geographical location in the northeast of Indian Territory (Littlefield 1978). Many in the South, especially Arkansas, wanted to shore up their western border by securing the Cherokee as allies in the wars to come. When secession was brought up in Arkansas, Governor Henry Rector appealed to Chief John Ross as "natural allies in war and friends in peace," jointly invested in the "application of slave labor." $" 55$ But

\footnotetext{
53 The Eastern and Western Cherokees. 1840. "An Act of Union," in The Constitution and Laws of the Cherokee Nation. Washington: Gales and Seaton.

54 Ibid.

55 Henry M. Rector to John Ross, January 29, 1861, $38^{\text {th }}$ Cong., $1^{\text {st }}$ sess., House Executive Document 1, pt. 3, 345. Quoted in Littlefield $(1978,10)$.
} 
although Governor Rector tried in instill in Ross a fear of Lincoln and the Union, Ross determined to remain neutral in whatever conflict the United States was contemplating.

It was during this turbulent time that, according to Patrick Minges, pivotal social divisions emerged within the Cherokee Nation (2003). While he was being pressured by Governor Rector to join the Confederacy, Chief Ross was soon caught between the proUnion Keetoowah Society, comprised of full-bloods, and the pro-Confederacy mixedblooded Knights of the Golden Circle (Littlefield 1878; Minges 2003). These organizations represented social divisions that had been brewing for many years due to the tensions brought on my mixing Cherokee and American social values and practices. The issue of slavery, as it had bitterly divided the United States, also affected the Cherokee, albeit in a different manner.

Debates over the moral arguments put forth by the Keetoowah Society notwithstanding, the Cherokee never seriously grappled with the moral ramifications of slaveholding and no serious "abolition societies were ever established" (Halliburton 1977, 11) ${ }^{56}$ As the Civil War drew closer, abolitionist missionaries in the Nation were often ostracized and the abolitionist cause avoided due to the troubles dealing with it would cause (Halliburton 1977, 93-104). The locus of division among the Cherokee was over slavery in the sense that traditional values were being expunged by the acceptance of white culture and civilization_ — cultural purity was of greater concern (Halliburton 1977; Littlefield 1978; Perdue 1979).

\footnotetext{
${ }^{56}$ Some scholars emphasize the abolitionist sentiments of the Keetoowah Society more than others. See Minges (2003) and Halliburton (1977) for a more in-depth look at these opposing viewpoints.
} 
By October 1861, Albert Pike, Confederate liaison to Indian Territory, had convinced each of the Five Civilized Tribes to join the Confederacy. ${ }^{57}$ The Confederacy's insistence, coupled with pressure and violence from the Knights of the Golden Circle, compelled Chief Ross to relent and sign a declaration of support for the southern cause (Littlefield 1978; Minges 2003). The Cherokee, however, did not go wholeheartedly into the fray. In December of the same year, Union troops began to move in force through Cherokee territory, causing many Cherokee to defect to the Union sideChief John Ross himself followed suit, eventually absconding to Philadelphia (Littlefield 1978, 11). By the end of the war, a majority of the Nation had joined the Union side. The war, however, had been disastrous for the Cherokee; Indian Territory had been devastated by 1865 (Gaines 1998).

In 1866, an official treaty between the United States and the Cherokee Nation was signed, granting amnesty to the Cherokee for joining the Confederacy (Abel 1925). But while the Treaty of 1866 essentially revoked and then restored many provisions of previous treaties, one important thing was changed: the definition of citizenship. The new treaty defined citizenship of the Cherokee Nation as belonging to all native-born Cherokee, all Indians and whites legally adopted by members, all freedmen liberated by acts of masters, and all free blacks residing therein (Littlefield 1978, 28). The terms of the treaty, and the new legal definition of Cherokee citizenship, were set to affect those who could be declared residents of Cherokee Territory within six months of the signing.

\footnotetext{
${ }^{57}$ The Five Civilized Tribes, as they have come to be known, include the Cherokee, Choctaw, Chickasaw, Creek, and Seminole tribes, all of which inhabited the Oklahoma "Indian" Territory on the eve of the Civil War (Bailey 1972).
} 


\section{The First Shift in Cherokee Citizenship: The Treaty of 1866}

The Treaty of 1866 was a major altercation between the US and the Cherokee over tribal citizenship. The provisions of the treaty significantly changed the meaning of Cherokee citizenship. Instead of only belonging to Cherokee by blood, the new law stipulated that formerly enslaved peoples, many with no blood relation, had to be included as legal citizens. After the Civil War, many in the Nation were disenchanted with their treatment by the US government and angry at their fellow Cherokee who had joined the opposing side. The Treaty of 1866 was a rallying point over which the Cherokee could unite on the issue of citizenship. While the United States saw the treaty as a means to finalize the end of slavery and simultaneously deal with the issue of the newly freed slaves in Indian Territory, the Cherokee actively resisted the redefinition of their tribal citizenship.

Alarmed at the United States' attempt to dictate to the Cherokee people who could be considered Cherokee, the National Council contended for the right to determine Cherokee citizenship by citing previous treaties and past US Indian policies. The Cherokee Council also opted for a strict interpretation of the 6-month provision in the Treaty of 1866 that acknowledged the citizenship of only those who returned to the Nation within six months of the treaty's signing. Six months, however, was not nearly enough time for those who had been displaced by the war to return to Cherokee territory — for years after the treaty, hundreds of freedmen and their families slowly migrated back to the Nation. These were routinely denied citizenship (Bailey 1972; Sturm 1998). 
In 1869, the Cherokee Council passed an act empowering the Cherokee Supreme Court to sit as commissioners to pass judgment on citizenship claims (Bailey 1972). Yet while the Cherokee set about asserting their authority to define their own citizenship, they quickly found that they could not handle the ensuing chaos caused by hundreds of people pouring into Cherokee Territory, claiming previous residence (Bailey 1972, 178-179). Lacking appropriate governing infrastructure to handle so many requests, many freedmen especially were either hastily denied or made to wait for long periods of time before action was taken. Those rejected for citizenship were periodically reported to the Commissioner of Indian Affairs along with a request for removal—a provision present in long-standing treaties (Bailey 1972, 179). The new status quo, however, proved to be untenable.

As early as 1871, the Office of Indian Affairs began instructing Union Agents in Indian Territory not to remove freedmen whom the Cherokee had classified as intruders (Bailey 1972, 180). The political situation in the Cherokee Nation was volatile. Cherokee public sentiment was deeply set against the United States interfering with Cherokee citizenship - the freedmen became a politically dangerous issue that no Cherokee politician wanted to touch (Wardell 1938, 229-231). After over a decade of struggling with the Cherokee National Council, the freedmen circumvented tribal government and appealed to the United States instead. The Union Agency told the freedmen and others who had troubles with the Cherokee National Council to come to them directly, thus further undermining tribal authority on the issue of citizenship (Bailey 1972, 181).

Despite the best efforts of the Cherokee to resist, the altered idea of citizenshipthat both blood Cherokee and freedmen were citizens of the Cherokee nation-prevailed. 
This change occurred because of both the American misunderstanding of Cherokee citizenship and the Cherokees' sin of slavery. After the Civil War, federal officials ignored the internal social divisions that existed within the Cherokee Nation and treated both Union and Confederate supporters alike (Sturm 2002, 74). The Confederate Cherokee wanted the United States to remove the freedmen from Indian Territory at their own expense while the northern Cherokee offered to make concessions for taking care of the freedmen on a separate tract of land (Wilson 1971, 233). The Cherokee were, in general, “opposed to adoption” (Halliburton 1977, 134). US government officials, however, went further, offering a plan "for the adoption of former slaves into the tribe, granting them citizenship, land, and annuities in the same amount" as blood Cherokee (Sturm 2002, 74).

The Treaty of 1866 and its redefinition of tribal membership marks the first durable shift in the idea of Cherokee citizenship. The Cherokee amended their Constitution in November 1866 to reflect the new definition of citizenship, as required by treaty. The new law stated that:

All native born Cherokees, all Indians, and whites legally members of the Nation by adoption, and all freedmen who have been liberated... as well as free colored persons who were in the country at the commencement of the rebellion, and are now residents therein, or who may return within six months from the $19^{\text {th }}$ day of July, 1866, and their descendants... shall be taken, and deemed to be, citizens of the Cherokee Nation. ${ }^{58}$

Further complicating the issue was the fact that the Cherokee Nation had adopted a large number of Delaware and Shawnee Indians during the 1860s as well (Sturm 2002, 75).

Circe Sturm has argued that the Cherokee resistance to incorporating the freedmen was "motivated largely by economic factors" $(2002,75)$. While economic factors certainly

\footnotetext{
58 See Halliburton 1977, 134-136.
} 
played a role in the Cherokee reluctance to invite new members into the polity, the analysis of Cherokee political thought presented in this chapter reveals that the Cherokee had deep-seeded cultural and ideological reasons for excluding the freedmen, and everyone else, from citizenship as well.

\section{The Second Shift in Cherokee Citizenship: The Dawes Rolls and Termination}

The Treaty of 1866, made possible by Cherokee participation in the war allied with the Confederates, shifted Cherokee citizenship policies away from one grounded in Cherokee political thought. After the treaty, Cherokee citizenship no longer solely included those sharing in Cherokee blood - citizenship would henceforth also include formerly enslaved peoples and all free blacks living in the Cherokee Nation who had no blood relation. The Cherokee did not readily accept this American liberalization of Cherokee citizenship. The Cherokee accepted the changes but refused to let more unrelated peoples into the Nation than absolutely necessary.

Cherokee refusal to bend the way the US wanted was evident in their policy of strict adherence to the six-month provision of the treaty. Thousands of freedmen and their families were thus turned away by the Cherokee and, also unwanted in the surrounding states, these freedpeoples appealed to the US government for sanctuary. US actions over the next few decades reveal a desire to use the freedmen's situation as a way to acquire more Indian lands. The more the Cherokee pushed freedmen away, the more US courts and legislation sided with the freedmen, thus undermining tribal sovereignty.

Another major altercation between the Cherokee and the United States began when the time came to receive payment for Cherokee lands sold to the US government. 
In 1883 , the Cherokee quickly passed an act declaring that the money, some $\$ 300,000$, should only be distributed among blood Cherokee (Bailey 1972, 182). The decision, passed over Chief Dennis Bushyhead's veto, excluded the freedmen from receiving any of the bounty. Desiring a share in the payment, many freedmen appealed to the Office of Indian Affairs directly, as they had been instructed in the past. Indian Affairs, having never viewed the Cherokee government as possessing actual power, began a larger political coup that led to the settlement of the issue of native sovereignty in the eyes of the US government (Sturm 1998, 235). ${ }^{59}$

After numerous attempts by the freedmen to gain access to Cherokee citizenship and benefits, Congress began passing major legislation on the topic, culminating in the Dawes Act of 1887 and the Curtis Act of 1898 (Sturm 1998). The Dawes Act began the process of converting the communally held lands within the Cherokee Nation to lots of individual ownership, hoping to modernize the Cherokee and make room for more white settlement on the leftover land (Sturm 1998, 235). The Dawes Act also established the Dawes Commission that was sent to compile a roll of residents living in Indian Territory. The Cherokee were greatly opposed to these measures and actively resisted efforts to count them for nearly five years (Littlefield 1978, 238; Sturm 1998).

The Curtis Act of 1898 passed into law when it became clear that the Cherokee would not cooperate. The Act gave the Dawes Commission authority to act without tribal consent, extended federal court jurisdiction over tribal land, and allowed the US to assume the tax payments of whites living within the Cherokee Nation (Debo 1940; Sturm 1998). The Dawes Rolls broke down the residents of Cherokee land into three categories:

\footnotetext{
${ }^{59}$ For a thorough exploration of Indian/US political struggles between 1866 and 1907, see Littlefield (1978).
} 
Cherokee, whites, and freedmen. All told, the inhabitants of the Cherokee Nation that the commission counted numbered 41,798, including 4,924 freedmen (Littlefield 1978, 238). There were over 1,000 freedmen who had been citizens previously, however, that were excluded from the Dawes Rolls — due to a mixture of clerical errors, inability to produce proof of citizenship, and racial profiling (Sturm 1998). In 1902, the finals rolls closed and in 1907 , the Cherokee Nation ceased to exist as Oklahoma was admitted to the union.

The Dawes Act—-that "mighty pulverizing engine to break up the tribal mass," as Theodore Roosevelt called it—set about simultaneously eliminating the Cherokee policy of holding land in common and allowing the federal government to physically count and name Cherokee citizens. ${ }^{60}$ The Cherokee lost their ability to hold lands in common, their ability to determine tribal citizenship, and, in 1907, the entirely of their tribal governing authority. The Dawes Rolls determined who was Cherokee from that point onward. Yet the nature of census taking at the time was imperfect—-factoring in the lack of cooperation from many Cherokee, the racial profiling of the census takers, and the inability to correctly place some people, the Dawes Rolls were a wholly flawed list (Littlefield 1978). In the short term, however, such inadequacies were immaterial as the US government had direct control over Cherokee affairs via the power to appoint governing leaders and dictate laws.

The Dawes Rolls and the termination of the Cherokee Nation mark the second durable shift in Cherokee citizenship. Up until 1907, the Cherokee Nation had faced political and practical problems that it was not given the authority or capacity to handle. Powerless to stop the inflow of settlers and business that followed the railroads, the Cherokee dug their heels in when it came to the personal issue of citizenship. By

${ }^{60}$ Theodore Roosevelt, "First Annual Message to Congress," December 3, 1901. 
dissolving the Nation completely, and by granting all Cherokee and freedmen alike US citizenship in 1924, the United States hoped to settle the messy issue of Native American sovereignty and make citizenship uniform once and for all. The Dawes Rolls became the standard by which US government officials determined who was and who was not Cherokee. Cherokee citizenship as a legal concept, however, lost its political power after the Nation ceased to exist.

\section{The Third Shift in Cherokee Citizenship: Self-Determination}

After the 1960s, a period that saw the United States concerned with civil rights and the elevation of minority populations, the Cherokee had their ability to self-govern reinstated. Upon the restoration of tribal sovereignty in the 1970 s, with the passage of the Five Civilized Tribes Act and the Principal Chiefs Act, the Cherokee again moved quickly to reassert their sovereign right to declare who was Cherokee, solemnly rejecting the uniformity of American citizenship (Sturm 1998, 251). ${ }^{61}$ In 1975, the Cherokee held a new constitutional convention and once again drafted a governing constitution-one vastly different from the versions that preceded it in the $19^{\text {th }}$ Century, similar in its commitment to Cherokee blood citizenship, yet different in its methods of securing it.

In the 1975 Constitution, rights language dominates the document-Article II is titled the Bill of Rights and refers directly to the US Bill of Rights and the protections guaranteed by the Indian Civil Rights Act of $1968 .{ }^{62}$ Membership was also retooled from

61 Principal Chiefs Act of 1970, Public Law 91-495, 91 ${ }^{\text {st }}$ Cong., $2 \mathrm{~d}$ sess. (October 22, 1970). The Act restored to the Cherokee the ability to elect via popular ballot the office of Principal Chief. Widespread popular elections followed, imbued with a renewed sense of the importance of the Cherokee Constitution and judicial system (Sturm 1998).

62 See 25 U.S.C. § 1301, which states that the "'powers of self-government' means and includes all governmental powers possessed by an Indian tribe, executive, legislative, and judicial, and all offices, 
its $19^{\text {th }}$ Century definition. Article III, Section 1 states that members of the Cherokee Nation "must be citizens as proven by reference to the Dawes Commission Rolls," including all incorporated Delaware and Shawnee Cherokees. The 1975 Constitution also established the Cherokee Registrar, responsible for maintaining the Cherokee Register. The Register existed for the inclusion of "any Cherokee for membership purposes who presents the necessary evidence of eligibility" for citizenship.

Put simply, when their ability to self-govern was restored by the United States, the Cherokee recommitted themselves legally to the spirit of blood citizenship. By using the Dawes Rolls as the standard by which to determine Cherokee membership, Cherokee leaders hoped to both appease the United States - since the Dawes Rolls were a US government project—and adhere to the core tenets of Cherokee political thought. Chief Ross Swimmer, in a December 1976 meeting, argued for the benefits of issuing membership cards to the Cherokee people. ${ }^{63}$ Realistically, the Dawes Rolls were the most practical means of making Cherokee citizenship exclusive again.

In many ways, the Cherokee Nation was establishing a government from the ground up in the 1970s. While guided by the lessons of history and ethnic republican principles, the Cherokee people, as Chief Swimmer put it, had to learn how to selfgovern. ${ }^{64}$ The activity of the National Council reflects that learning process—especially on the issue of citizenship. Figure 2.2 depicts the number of citizenship laws or resolutions as a percentage of total legislative activity for every year since 1976.

bodies, and tribunals by and through which they are executed, including courts of Indian offenses; and means the inherent power of Indian tribes, hereby recognized and affirmed, to exercise criminal jurisdiction over all Indians." The constitutional rights of Indians include all negative rights possessed by United States' citizens as enumerated in the Bill of Rights.

${ }^{63}$ Wheeler, R. Perry. 1976. “Minutes of Regular Meeting, December 4, 1976," Tahlequah: Cherokee Nation Council.

${ }^{64} \mathrm{Ibid}$. 
Citizenship laws here include all legislation or resolutions concerning elections, voting, holding office, membership in the community, or cultural heritage.

The legislative activity on citizenship matters reflect the Cherokee desire to use racially hegemonic concepts to legitimize social identities (Sturm 1998, 231). The peaks in Figure 2.2 fall over important events in the growth of the new Cherokee Nation. The ascension of Wilma Mankiller into the role of Principal Chief after the resignation of Chief Swimmer in 1985- and her subsequent election as the first female Principal Chief in 1987-instigated a reexamination of Cherokee voting practices and government infrastructure. The concentration of citizenship legislation in the early 1990s and the early 2000s reflects the Cherokee desire to govern efficiently within a clearly demarcated socio-political community, distinguished by blood, color, and race. As in the $19^{\text {th }}$ Century, these Cherokee efforts were challenged by descendants of freedmen, who were, because of the foundational concepts of Cherokee political thought, excluded from that idea of citizenship.

The wave of citizenship activity — the continual updating of election rules and voting procedures or eligibility —in the early 1990s, along with the relative weakness of the Cherokee governing infrastructure, contributed to the need for another constitutional convention. The late 1990s also saw increased political division among leadersNational Council members frequently boycotted council meetings during Chief Byrd's administration. ${ }^{65}$ The Cherokee government was largely unequipped to handle basic governing practices and needed to adapt.

\footnotetext{
${ }^{65}$ Eagle, James Garland. 1998. “Unofficial Draft Minutes of Special Tribal Council Meeting, May 23, 1998," Tahlequah: Cherokee Nation Council. In a public council meeting deemed unofficial due to the lack of a quorum, Councilman Harley Tarrell spoke at length condemning the ongoing boycott and ineffectiveness of the current system of government for representing Cherokee interests.
} 


\section{Figure 2.2: Percentage of Total Cherokee Legislation on Citizenship, 1976-2018}

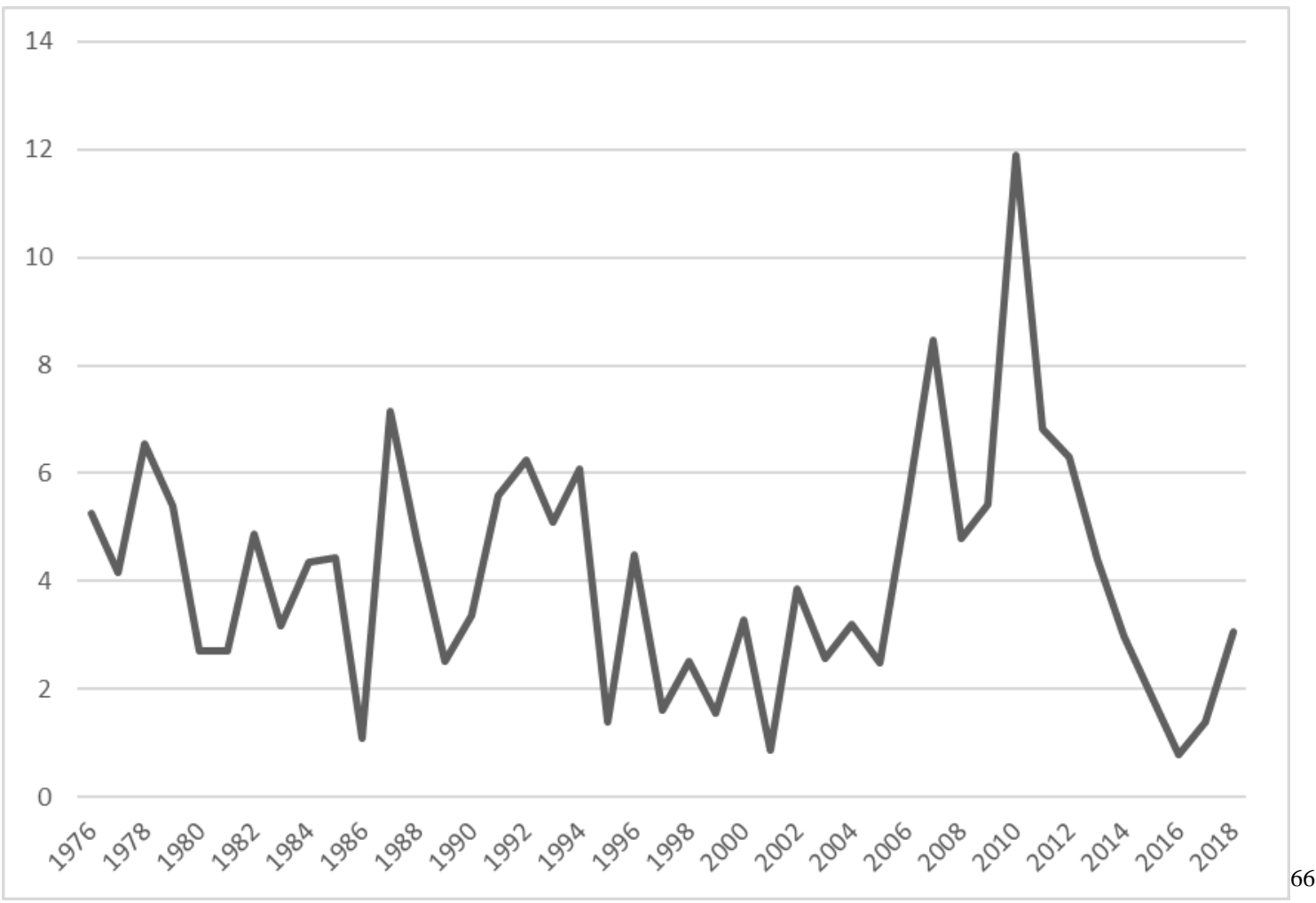

The wave of citizenship activity - the continual updating of election rules and voting procedures or eligibility — in the early 1990s, along with the relative weakness of the Cherokee governing infrastructure, contributed to the need for another constitutional convention. The late 1990s also saw increased political division among leadersNational Council members frequently boycotted council meetings during Chief Byrd's administration. ${ }^{67}$ The Cherokee government was largely unequipped to handle basic governing practices and needed to adapt.

${ }^{66}$ Data collected from the Council of the Cherokee Nation Legislative Research Center, https://legislative.cherokee.org/ (accessed June 5, 2019).

${ }^{67}$ Eagle, James Garland. 1998. "Unofficial Draft Minutes of Special Tribal Council Meeting, May 23, 1998," Tahlequah: Cherokee Nation Council. In a public council meeting deemed unofficial due to the lack of a quorum, Councilman Harley Tarrell spoke at length condemning the ongoing boycott and ineffectiveness of the current system of government for representing Cherokee interests. 
The 1999 Constitution gave the Cherokee government significantly more authority to act on Cherokee interests. All legislative activities increased as the Cherokee took greater control over taxation, expenses, social programs, and governing sovereignty. The Cherokee remained consistent in their definition of citizenship —in fact, Article IV of the 1999 Constitution was the most explicit description of Cherokee citizenship of all four governing documents. While the reliance on the Dawes Rolls remained, the 1999 Constitution placed more emphasis on the sovereign right of the Cherokee to self-govern and self-determine. The principle of self-determination carried into the Chief Smith Administration — elected in 1999 — which saw an overall increase in policies reaffirming Cherokee culture, ancestral practices, and sovereignty. The renewed push for sovereignty culminated in a vote to amend the 1999 Constitution in 2003. The amendment, which passed with 62 percent of the vote, removed the US federal approval requirement from the Cherokee Constitution. ${ }^{68}$ That is to say, the Cherokee wanted to increase their sovereign authority by asserting that they could define citizenship how they wanted without US approval.

One of the side-effects of this amendment was that the Cherokee government gained more control over citizenship and voting. Practically, this amendment led to the exclusion from citizenship of many descendants of freedmen and those who could not prove blood ancestry by relation to someone listed on the Dawes Rolls. ${ }^{69}$ Challenges to the amendment were seemingly put to rest by the Cherokee Supreme Court in 2011.

\footnotetext{
${ }^{68}$ Cherokee Nation. 2003. "Cherokee Nation Election Results," Tahlequah: Cherokee Nation Director of Communications.

${ }^{69}$ Cherokee Nation Registrar v. Raymond Nash et al., SC-2011-02 [Supreme Court of the Cherokee Nation, 2011].
} 
Chief Justice Matlock argued that "it stands to reason that if the Cherokee had the right to define citizenship" in 1866 , then they would have the "sovereign right" to change it. ${ }^{70}$

The United States, however, as they had done previously, ruled repeatedly in favor of freedmen families. In 2007, the Bureau of Indian Affairs denied the validity of the amendment, stating that the Cherokee were in violation of the Treaty of 1866 and could not deny citizenship rights to sections of their population. ${ }^{71}$ Later that same year, Representative Diane Watson (D-CA) introduced a bill designed to sever US ties with the Cherokee Nation unless they granted full citizenship to the descendants of freedmen. ${ }^{72}$

Finally, in August 2017, US District Judge Thomas Hogan remarked that while it is known that Native Americans have been often marginalized and removed from their lands, it is also the case that the Cherokee do not have the authority to deny citizenship to those descendants of their freedmen previously established. ${ }^{73}$ As the results of Hogan's ruling indicate, Cherokee citizenship is legally defined as including all Cherokee, all white and others adopted, and all freedmen and their descendants. Legally, the United States' redefinition of Cherokee citizenship has prevailed. While the Cherokee still retain some measure of self-determination, the United States has had the final say over who counts as Cherokee.

The Congressional policy of Native American Self-determination that led to the rebirth of the Cherokee government constituted the third durable shift in Cherokee

${ }^{70}$ Ibid., 8.

${ }^{71}$ Snell, Teddye. "BIA Disputes Tribe's Removal of Feds from Constitutional Process." Tahlequah Daily Press [May 23, 2007]. https://www.tahlequahdailypress.com/news/local news/bia-disputes-tribe-sremoval-of-feds-from-constitutional-process/article 11eed474-a578-5364-a999-0a429331fe9e.html [accessed November 26, 2018].

${ }^{72}$ A Bill to Sever United States' Government Relations with the Cherokee Nation of Oklahoma, HR 2824, $110^{\text {th }}$ Cong., $1^{\text {st }}$ sess., Congressional Record 153, no. 147, daily ed. [October 1, 2007]: H 11053.

${ }^{73}$ The Cherokee Nation v. Raymond Nash et al. and Marilyn Vann et al. and Ryan Zinke, Secretary of the Interior, and the US Department of the Interior, 13-01313 (TFH) [United States District Court for the District of Columbia, 2017]. 
citizenship. While, prior to 1975 , Cherokee citizenship carried little political weight beyond Cherokee communities, after the Cherokee ratified their new constitution, tribal membership received new political vigor. The Cherokee moved quickly to assert their national sovereignty by again formally restricting citizenship to descendants of those listed on the Dawes Rolls. Freedmen and others who could not prove relations to anyone listed—although they had been physically residing in Cherokee communities their entire lives - were excluded (Sturm 2002). The freedmen and others pushed back. Legal battles continued for years until 2017, when a US district court ruled that Cherokee citizenship must be afforded to freedmen as well, based on those listed on the Dawes Rolls.

\section{Cherokee Citizenship, 1975-2018}

The search for durable shifts in Cherokee citizenship policies from 1975 to 2017 finds two more major altercations with the United States. The first shift came in the 1970s, when the Cherokee were given control of their tribal government back by Congress. Immediately, the Cherokee reaffirmed their commitment to hereditary citizenship and an exclusive culture of Cherokee values. By 1992, the Cherokee had codified paths to citizenship — while expanded slightly to include adoptions and other nontraditional familial attachments, citizenship remained driven by the Dawes Rolls and blood heritage ${ }^{74}$ While this first altercation was over Cherokee identity, the second concerned Cherokee sovereignty in a more fundamental way. After the 1999 Constitution was ratified, a wave of legislative activity was targeted at increasing the influence of Cherokee culture. The 2003 amendment and the fallout from it show the Cherokee

\footnotetext{
${ }^{74}$ Legislative Act 6-92 - An Act Relating to the Process of Enrolling as a Member of the Cherokee Nation.
} 
attempting to expand their governing authority against the United States. The effort, as of 2017, has failed. The definition of citizenship as including both Cherokee and freedmen unrelated by blood as listed on the Dawes Rolls has been upheld. Moreover, the United States ruled that the Cherokee do not have the sovereign right to change their definition of citizenship to exclude currently included peoples.

An analysis of how Cherokee citizenship developed then reveals at least three major shifts in policy. It remains to be seen whether the 2017 court ruling will endure without further challenges by the Cherokee Nation. Table 2.1 displays the progression of Cherokee citizenship policies over time. The dominant policy prior to 1866 was a very strict, racially-based vision of citizenship as being explicitly derived from the Cherokee bloodline. The racial component reflected the same prejudices of white society against members of the African race, except the Cherokee specifically codified this prejudice into their 1827 and 1839 Constitutions. Membership in the Cherokee community was reserved only for those part of the greater Cherokee family.

The Treaty of 1866 changed this policy. The Cherokee, to return into the good graces of the government they had partially rebelled against, were forced to submit to the inclusion of their freedmen as citizens of the Nation. The treaty was ratified, however, with a six-month provision that gave the Cherokee the authority to refuse entry to those appealing for citizenship more than six-months after the signing. The new policy, for the next twenty years, was a strict interpretation of the treaty and the routine refusal to admit those who came late into Cherokee territory.

During the period between 1887 and 1907, the United States, using the freedmen as leverage, chipped away at Cherokee sovereignty in order to claim both land and 
dominion. Cherokee resistance to the intended incorporation of formerly enslaved peoples as members of the community was rendered obsolete by the dissolution of the Cherokee Nation when Oklahoma became a state in 1907. The Cherokee government thereafter possessed token authority to decide on many matters of governance.

Table 2.1: Shifts in Cherokee Citizenship, 1866-2018

\begin{tabular}{|c|c|c|c|c|}
\hline Date of Shift & 1866 & 1887-1907 & 1970-1975 & 2003-2017 \\
\hline $\begin{array}{c}\text { Old Cherokee } \\
\text { Policy }\end{array}$ & $\begin{array}{l}\text { Cherokee blood, } \\
\text { excluding African } \\
\text { race }\end{array}$ & $\begin{array}{l}\text { Cherokee blood } \\
\text { plus freedmen } \\
\text { unrelated, strict }\end{array}$ & $\begin{array}{c}\text { All equal } \\
\text { Cherokee } \\
\text { citizens, Nation } \\
\text { Dissolved }\end{array}$ & $\begin{array}{c}\text { Cherokee blood } \\
\text { based on Dawes } \\
\text { Rolls, strict }\end{array}$ \\
\hline $\begin{array}{c}\text { New Cherokee } \\
\text { Policy }\end{array}$ & $\begin{array}{l}\text { Cherokee blood } \\
\text { relation plus } \\
\text { freedmen } \\
\text { unrelated, strict }\end{array}$ & $\begin{array}{c}\text { All equal } \\
\text { Cherokee } \\
\text { citizens, Nation } \\
\text { dissolved }\end{array}$ & $\begin{array}{c}\text { Cherokee blood } \\
\text { based on Dawes } \\
\text { Rolls, strict }\end{array}$ & $\begin{array}{c}\text { Cherokee blood } \\
\text { based on Dawes } \\
\text { Rolls plus } \\
\text { freedmen also } \\
\text { listed }\end{array}$ \\
\hline $\begin{array}{c}\text { Reason for } \\
\text { Shift }\end{array}$ & Treaty of 1866 & $\begin{array}{c}\text { Dawes Act, } \\
\text { Oklahoma } \\
\text { Statehood }\end{array}$ & $\begin{array}{c}\text { Principal Chiefs } \\
\text { Act, New } \\
\text { government }\end{array}$ & US court rulings \\
\hline
\end{tabular}

The third shift occurred sixty years later, after a build-up of civil rights legislation in Congress and President Nixon's efforts to reestablish Indian control over their own affairs. Once the Cherokee government was reestablished, the 1975 Constitution reaffirmed the idea of blood ancestry as essential to Cherokee politics. The new policy quickly become a strict adherence to those families and names listed on the Dawes Rolls. Blood Cards were issued to members of the Nation so that they could participate in tribal activities, including voting or running for office. This policy shifted after thirty years of pushing back against the United States' authority over Cherokee affairs. The United States repeatedly sided with the descendants of freedmen who had been disenfranchised 
by the Cherokee before and especially after 2003 . As of 2017, the prevailing citizenship policy in the Cherokee Nation includes all those who can prove relation to someone listed on the Dawes Rolls and those who have previously held citizen status, regardless of Cherokee blood relation. The Cherokee, however, continue to demarcate their membership by excluding all others.

\section{Cherokee Political Thought: The Importance of an Idea}

The development of Cherokee citizenship reveals a story of attempted liberalization and the resilience of ancestral political principles. We observe in this development not only the importance of understanding historical events but also how ideas may persist and manifest themselves in practical ways. Cherokee political thought, while it has been nudged toward a model of American liberalism over time, has remained committed to the idea of hereditary citizenship.

Part of this commitment has been due to the Cherokee delineation between a citizen and a member of the community. Rose Stremlau's work on Cherokee communities after allotment reinforces this point. As the United States slowly transformed Cherokee communal lands into individual plots, the Cherokee people banded together with renewed determination to preserve their sacred ties and traditions (Stremlau 2011, 165-170). It was during the late $19^{\text {th }}$ Century, as the Dawes Commission was collecting data, that the Cherokee experienced a cultural revival. The Old Ways were once again studied, new stomp grounds were erected throughout the territory, and spiritual leaders, like Redbird Smith, gained public support in their efforts to preserve Cherokee heritage (Stremlau 2011, 165-168). 
Today, the Cherokee Nation dedicates time and resources to spreading the message of what it means to belong to the Cherokee $(2010 ; 2017)$. The work Cherokee National Treasures, a celebration of individuals who have become specialized in ancient Cherokee artwork, customs, or wisdom, argues that "it is not the color of our skins or the blood in our veins [that make us Cherokee]. Being Indian is a way of life, living and remembering our past" (Cherokee Nation 2017, 3). The threats to Cherokee tradition and custom over time have driven many in the Nation to reaffirm old practices and celebrate their unique cultural heritage, sometimes to the exclusion of others.

The distinction between a citizen and a member of the community has been one superimposed on the Cherokee by contact with the United States. Ancestral political principles, in this instance, posit a relationship closer to an ethnic republicanism rather than classical liberalism. The development of Cherokee citizenship policies reflects this tension. As circumstances changed, and they were forced by necessity to adopt aspects of white civilization, the Cherokee found themselves less able to determine their own practices or cultural trajectory.

Cherokee ancestral identity has been alternately threatened and undermined by the inevitable mixture of race and ethnicity that white civilization brought with it. The institution of slavery was viewed by the Cherokee as a tool, first favored and then rejected by white society (Halliburton 1977). The Cherokee were shocked by the sudden request made of them to count those with whom they shared no blood as brothers and sisters. The Cherokee were especially incensed by the demands made by Congress that they share payment and other benefits intended for Indians only with formerly enslaved peoples. By viewing Cherokee citizenship through the lens of ancestral political thought, 
we are better able to understand why certain tensions exist and why the debate between the Cherokee and United States is ongoing.

These tensions between the United States and indigenous peoples remain relevant, not only because of the legal battles over Cherokee citizenship, but also because of continued attempts to use Indian Territory for industry. As recent stories such as the Standing Rock protest suggest, the struggle between the United States and Indian nations over issues of sovereignty has not been resolved. That the election of 2016 stirred up a renewed interest in national belonging may also be an indication that the situation in the Cherokee Nation is far more complicated than it may seem. Additionally, claims made by Senator Warren have brought to light debates surrounding what it means to be Cherokee and whether a Cherokee citizen is different from a member of the Cherokee Nation. 


\section{Chapter 3: Toward the Sitting Sun: An Analysis of Federal Indian Policy}

Ideas favor and privilege certain institutions (Dow 2017, 8). Foundational political ideas find their empirical referents in institutional designs (Orren and Skowronek 2011; Dow 2017, 298). Actors working within the confines of institutional rules are, therefore, necessarily limited in what they can and cannot do. Policymaking needs may drive the rise of rules, leadership structures, and committee systems (Squire 2012, 1), yet these referent points derive their form from the ideas upon which they were grounded. For example, the Framers of the US Constitution knew that members of Congress needed to be popularly elected to legitimate the idea of representative government. The US single-member district electoral system was not inevitable, but rather one of several potential options for electing representatives (Dow 2017, 16-17). Popular sovereignty, liberalism, and republicanism are foundational ideas that ultimately answer "why" the US has single-member districts; single-member districts answer "how" those foundational ideas manifested themselves in political reality (Dow 2017, 244).

Indian policy works in a similar way. American institutions are based upon certain foundational ideas, yet created through a process of "adaptive evolution," by which officials retain the strongest aspects of institutional design and discard the weakest (Squire 2012, 2). These institutional norms therefore necessarily admit little leeway for government officials to decide how to treat indigenous peoples and their political communities. If US institutions are based upon certain foundational ideas (e.g., political equality under the law, individual inalienable rights, government is instituted for the good of the people, etc.), then the institutional rules and norms that those ideas drive should 
restrict political actors from simply doing whatever they want. ${ }^{75}$ Essentially, the pyramid of ideas making up American political thought, upon which US institutions are ostensibly founded, suggests certain tensions with indigenous politics, or Cherokee political thought. That tension should be revealed in institutional actors' dealings with the Cherokee and indigenous peoples - especially in how those actors presented arguments in support of their actions. The biases toward American political thought harbored by the individuals who populate governing institutions are not, in and of themselves, malicious toward the Cherokee. I argue that natural tensions are inevitable between the US and the Cherokee that are best understood through the lens of ideological incongruence. ${ }^{76}$

While American political thought is not a static concept, there are certain revered principles that have transcended political time. Among these principles are popular sovereignty, government by consent, individual rights, equality under the law, nonhereditary citizenship, and private property (West 2017). Cherokee political thought, as discussed in the previous chapter, differs in a few critical ways. For the Cherokee, hereditary citizenship was an essential component of their political thought, as it reflected how they constructed their views of both family and politics. Additionally, private property meant something different for the Cherokee - communally held lands were

\footnotetext{
75 The ideas upon which American institutions are founded is, of course, a highly contested topic (Morgan 1975; McDonald 1985; Hartz 1991; Smith 1997; Dyer 2012; Squire 2012; Seagrave 2015; Dow 2017; West 2017). I take the view that ideas matter in the construction and perpetuation of political institutions. Institutions, however, and their various intricacies, may be more or less in line with the spirit of the foundational ideas underpinning them (Kettner 1978; Smith 1997).

${ }^{76}$ This is not to distract from, as President Ulysses Grant put it, "the avarice of the white man" or what President Rutherford Hayes termed the "acts of injustice on our part" as sources of conflict between the United States and Native Americans (Grant, "Eighth Annual Message to Congress," December 5, 1876; Hayes, "First Annual Message to Congress," December 3, 1877). Excellent scholarly work has already identified greed and racism as powerful motivators for United States officials in their dealings with the Indians (Green 1982; McLoughlin 1986; Purdue 2016). Where my project differs is in the emphasis placed on the ideological differences between the United States and the Cherokee Nation. Without understanding the ideological piece of the puzzle, scholars tell an incomplete story of US-Cherokee relations and, as it relates to this dissertation, Cherokee citizenship.
} 
necessary for the public good. These and other differences_-views on religion and sovereignty — shaped how the Cherokee viewed and have come to view citizenship.

As larger institutions — adding a power imbalance to the ideological tensionCongress, the Presidency, and the Supreme Court have asserted authority over the Cherokee in how they define tribal citizenship. As a result of the differences between American and Cherokee political thought, American political actors, while simultaneously influenced by racial prejudice and acquisitiveness, have, because they are guided by American political thought, attempted to reshape how the Cherokee decide who is Cherokee and, importantly, what it means to be Cherokee. The legal definition of Cherokee citizenship evolved from "all Cherokee related by blood" in 1827 to "all Cherokee, including freedmen, who are able to prove relation to someone listed on the Dawes Rolls" in 2019. That change is dramatic. The ultimate cause of that change is how US institutions have interpreted who the Cherokee are and what power they possess over their own people.

In this chapter, I present an overview and analysis of federal Indian policy since 1787, to set the stage for institutional case studies in chapter four. This overview permits a greater understanding of the course of Indian policy over time and illuminates patterns in government officials' collective behavior. The federal Indian policy timeline depicted here is the result of all three major US institutions combined efforts to deal with indigenous peoples. Whatever the President, members of Congress, or Court justices believed and argued at a given time, the overarching federal Indian policy was the net result. Sometimes Court justices disagreed with the President and Congress. Sometimes the President stood alone. This chapter deals with federal policy as a whole. In chapter 
four, I conduct three case studies to see whether actors in each political branch of government individually understood Cherokee political thought. Here, my goal is to provide context for the discussions and analysis of Indian policy to come.

\section{An Overview of Federal Indian Policy}

Over time, US institutional actors have exhibited a pattern of challenging Cherokee identity via legislation and other political activity. While scholars have different terms for different systems of Indian policy (Prucha 1976; Taylor 1980; French 2016), there are general identifiable Indian policy eras in American history. Table 3.1 provides a basic overview of the history of federal Indian policy in the United States. As stated in the previous chapter, assimilation policies generally entailed making Indians like Americans. What being American meant, of course, changed over time (Smith 1997; Huntington 2004). In the first period, assimilation and civilization, the US government avoided confronting the most vexing problems of Indian-white relations, like the major political golf that existed between them (Saltz 1975, 1). Civilizing the Indians in this period meant instructing them on how to build towns, cities, farms, schools, churches, and seats of government to emulate the dominant American way of life (Saltz 1975, 2).

The civilization policy was effective, but not in the way that US officials had hoped. Congressmen had hoped that Indians would fully assimilate into American society — and give up their large areas of communally held land to new settlements in the process (Perdue and Green 2007, 20-31). Part of the reason that the federal government avoided dealing with many serious Indian problems in the early period was because many tribes fled west on their own to avoid altercations with white settlers (Saltz 1975, 1-3). 
Since they wanted land, the US was content to let the Indians leave and permit settlers to inhabit the remains. When civilizing indigenous peoples resulted in the substantial westernization of many tribes, including the Cherokee who formed a constitutional government, the United States found that eastern Indians became politically entrenched, better able to legally defend their land titles (Saltz 1975, 3; Perdue 2016, 13-14).

Politicians, therefore, increasingly saw Removal as an attractive option (Green 1982).

Table 3.1: Overview of Federal Indian Policy by Time Period

\begin{tabular}{|cc|}
\hline Congressional Indian Policy & Time Period \\
\hline Assimilation and Civilization & $1787-1816$ \\
Assimilation and Removal & $1816-1829$ \\
Forced Removal & $1830-1868$ \\
Peace and Assimilation & $1868-1876$ \\
Allotment and Assimilation & $1877-1887$ \\
Assimilation and Termination & $1887-1934$ \\
Reorganization & $1934-1954$ \\
Termination and Relocation & $1954-1968$ \\
Self-determination & $1968-1989$ \\
New Federalism and Self-determination & $1989-2019$ \\
\hline
\end{tabular}

Removal was a policy different yet derived from assimilation and civilization (Perdue 2016, 7-11). By the 1820s, civilization policies were succeeding, but this goal counteracted the implicit goal of acquiring Indian lands (Saltz 1975, 2). US government officials in the 1820 s were hopeful that indigenous peoples would voluntarily move west; 
yet when the Cherokee declared their sovereignty to the world in the form of a constitutional government, a new racial prejudice emerged that suggested that the Indian could never be civilized the way that Americans wanted (Perdue 2016, 15). Forced removal seemed to many the only option. This policy was put into law by the $21^{\text {st }}$ Congress in 1830 - this legislation granted power to the president to remove Indians by force (French 2016, 46-47). A great host of indigenous peoples were marched west, past the Mississippi (Foreman 1932). The creation of a new Indian Territory and the ensuing American Civil War, however, did not deter westward expansion.

Peace and assimilation policy was designed to end US-Indian hostilities and, in partnership with Christian humanitarian groups, increase the cultural assimilation of indigenous peoples (Fritz 1963, 56-62). When the clash between Union and Confederacy ended, the United States still faced hostilities on the western frontier (Fritz 1963, 56-57). Faced with a governance problem throughout the west, the United States attempted to secure for frontiersmen settlers a stable form of justice by tightening its grip on the Indians and redoubling efforts to culturally absorb native peoples. Christian missions, as they had done since the Founding, continued to set up schools and churches in earnest, many out of a genuine humanitarian desire to see suffering people alleviated from hunger, depression, war, and disenchantment with the American way of life (Fritz 1963; Prucha 1976).

Allotment, which flowed out of the increased pressure placed upon Congress by railroad companies, settlers, and frontier towns — and the pleas of freedmen, like those living within the Cherokee Nation — was designed to break up the tribal land masses and push them further toward Americanization (Stremlau 2011, 130-131). This policy was a 
more aggressively direct form of civilization policy. Congress and other American politicians specifically targeted the prevailing Cherokee practice of holding lands in common. It was easier to get land for settlers and railroad companies by simply giving each indigenous family or person a tract of land and claiming the rest as open for American use (Littlefield 1978; Duthu 2008, xvi). Termination is related. It was hoped through allotment that Indians would continue hastily toward Americanization. Termination finally saw the end of tribal governments as the Five Civilized Tribes were dissolved when Oklahoma was admitted to the Union as the $46^{\text {th }}$ state in 1907.

Termination and assimilation continued into the 1930s. In 1924, Congress passed the Indian Citizenship Act, which "conferred US citizenship on noncitizen Indians" (Duthu 2008, xvi). During the debates in the House of Representatives over the Indian Citizenship Act, Rep. William Hastings (D-OK) spoke of the end of Indian affairs, stating that "during the present session of Congress everything has been done that has been possible to wind up the affairs of the Five Civilized Tribes."77 Government officials during this period remained hopeful that Indian affairs could be resolved and native peoples fully assimilated into American culture and lifestyle. The persistence of tribal organizations, culture, and practice — combined with a continued problem of policing and governance after the failure of allotment to improve economic conditions among indigenous peoples (Taylor 1980, 6-7) — however, eventually forced a reappraisal of the situation in the 1930 s.

The Indian Reorganization Act of 1934 declared Congress' intention to end allotment period policies and permit tribes to organize for political and economic reasons (Duthu 2008, xvi). During the 1920s, there was a growing sense among reform groups

\footnotetext{
${ }^{77}$ Congressional Record, $68^{\text {th }}$ Cong., $1^{\text {st }}$ Sess., 9674.
} 
that Indian life needed to be drastically improved (Taylor 1980, 15). Reform movements culminated in the Reorganization Act that sought to "revive traditional tribal institutions and integrate them with a program" for economic rehabilitation (Taylor 1980, 17). Yet while Congress was willing to grant more autonomy to tribes, there was still doubt that Indians were ready for self-government — the allotment and termination periods had sunk many into extreme destitution and the lack of strong internal government had bred corruption (Taylor 1980, 19). The momentum of this policy era changed, however, after WWII ended and bureaucrats believed the restoration of tribal governments outdated in the new world order (Fixico 1986, ix).

Termination and relocation constituted a new plan to terminate the "government's trust relationship over Indian lands" and relocate native residents to new homes in urban centers (Fixico 1986, ix). Former Chief of the Cherokee, Wilma Mankiller, who was relocated under this policy - the Urban Relocation Program (Duthu 2008, xvii)—as a little girl, explained that the "government wanted to break up tribal communities and 'mainstream' Indians," so they moved them to where they might become more American (Mankiller and Wallis 1993, xx). House Concurrent Resolution 108 in 1953 "announced Congress' purpose to end tribal wardship" and "sever federal obligations to tribes" to facilitate assimilation (Duthu 2008, xvi). These bills passed Congress with "little discussion" as they were often cloaked by larger issues (Fixico 1986, 94).

The Indian self-determination movement emerged from the civil unrest of the 1960s and was directed against the "combined effects of termination and relocation" (French 2016, 66). There were disagreements among US government officials at all levels over what exactly self-determination meant—in general, however, they "agreed 
that self-determination meant self-government for Indian tribes and economic development" (Gross 1989, 31). Protests, increasing pressure on Congress from interest groups and reformers, and general societal upheaval led to the Indian Civil Rights Act of 1968, which imposed upon tribes the protections guaranteed by the US Bill of Rights (Duthu 2008, xvii; French 2016, 66). The Indian Self-Determination and Education Assistance Act followed in 1975 and provided avenues for Indian leaders to contract with federal agencies to fund their own programs (French 2016, 67). This was done to combat the corruption that resulted from termination and relocation policies. Yet selfdetermination has not been a consistent concept.

Self-determination has meant many different things to different people and currently exists as a vague ideal governing federal Indian policy (Gross 1989, 32-34; French 2016, 143-155). In general, self-determination reflects a desire for Indian participation in and control over policies and programs that affect Indian life (Gross 1989, 34). It is unclear, however, whether self-determination means that Indian governments should be led back to the type of political sovereignty they once held as independent nations. Under the Reagan Administration, self-determination was called the New Federalism, which called for great tribal authority and more federal oversight (French 2016, 125-126). New Federalism was created by a 1989 US Senate Special Committee on Investigation of the Select Committee on Indian Affairs report that detailed the list of abuses committed against indigenous peoples and provided a basis for potentially correcting those errors (French 2016, 125). The result has been the increased ability of the federal government to intervene in Indian country under any pretext - this 
ability became even more invasive with the creation of the Department of Homeland Security (DHS) and the combined war on drugs and war on terror.

\section{The Relationship between Federal Indian Policy and Cherokee Citizenship}

An analysis of federal Indian policy reveals an ebb and flow in the acknowledged political authority of Indian Nations, including the Cherokee. In the first period, tribes were afforded more space and leniency. When it became clear that land could not be obtained easily, Congress pursued more restrictive policies. After the Civil War, Congress again eased back their pressure, but only briefly. Allotment and eventual termination wiped out tribal governments completely. During the 1930s, an effort was made by Congress to reverse the termination policies of the past, but that effort ended in the 1950s with renewed efforts to terminate and assimilate tribes. Congress in the 1960s and 1970s again reversed its direction with an ongoing commitment to Indian selfdetermination, but what exactly self-determination ultimately means is still under discussion.

Congress has also viewed Cherokee citizenship differently in different time periods. From the beginning, when Congress and other US officials adopted a policy of civilization and assimilation, Cherokee sovereignty-and therefore Cherokee tribal membership — was not taken seriously. ${ }^{78}$ Again, civilizing the Cherokee meant educating them in the ways and means of western society and culture. The implicit congressional understanding in this period was that the Cherokee way of life needed improvement, that

\footnotetext{
${ }^{78}$ Before the ratification of the Cherokee Constitution in 1827, the use of the term Cherokee citizenship as a legal distinction is incorrect. Tribal membership or belonging would be more accurate phrases to describe those belonging to Cherokee communities. I use the term citizenship in conjunction with the Cherokee after 1828.
} 
Cherokee culture was deficient in a civilized world. Christian missionaries — many with genuinely good intentions and hearts for indigenous peoples who they saw as poor and suffering — dedicated their efforts to uplifting the Indian and making them in the model of white civilians (Prucha 1976). Congressmen, however, generally saw being Cherokee as savage, miserable, and generally wasteful. ${ }^{79}$

Figure 3.1 shows the state of Cherokee citizenship before and after the Congressional policy of civilization and assimilation. This figure combines the first two periods listed on Table 3.1, because the policy of assimilation and removal was very similar to civilization and assimilation. Congress throughout this period, when they did, encouraged a voluntary removal. In 1787, Cherokee belonging was based on close familial ties - they had not yet coalesced into a unitary government. US efforts to civilize and assimilate the Cherokee resulted, against the intentions of Congress, in the Cherokee forming a unified constitutional government. Cherokee citizenship became a legal concept, as well as a familial one. The concept of belonging to a large kinship-based society now had legal backing in the new constitution.

When the Cherokee proved adept at civilizing (McLoughlin 1986, 277-279), the power commanded by the Cherokee Constitution and newly minted legal citizenship was such that it forced the US to acknowledge the Cherokee as a potential threat and drew the ire of congressmen who strongly advocated removal. In this sense, Congress created, in the first policy era, what they considered to be a problem in need of speedy remedy. The

${ }^{79}$ I mean wasteful in the Lockean sense. In the Second Treatise, Locke asks "whether in the wild woods and uncultivated wastes of America left to Nature, without any improvement, tillage or husbandry, a thousand acres will yield the needy and wretched inhabitants as many conveniences of life as ten acres of equally furtile land doe in Devonshire where they are well cultivated" (1960, V.37.24-29, emphasis mine). Early America was heavily influenced by Locke's writings (Hartz 1991; Smith 1997). The idea of uncultivated territory (in the laborious Lockean sense) was irksome to many, including settlers and frontiersmen, who viewed the Indian person as lazy or deficient. 
perceived problem was the increased legal confidence and refusal to move of the Cherokee, including the bold Cherokee statement of tribal sovereignty in their 1827 Constitution. The speedy remedy was removal. While Congress did acknowledge Cherokee citizenship at this time, they also disregarded its ultimate legitimacy. Once pushed west, the Cherokee were, compared to later periods, left to their own devices. Cherokee politicians, as they resolved their internal differences through debate and violence (Littlefield 1978), re-solidified the legal concept of Cherokee citizenship in the new Cherokee Constitution of 1839. Missionaries, of course, continued their efforts to assimilate the Cherokee into Christian culture. The Civil War, however, brought with it new challenges and turmoil. By joining the Confederacy — after succumbing to intense political pressure to do so - the Cherokee assured that they would be assailed again after a Union victory.

Figure 3.1: Federal Policy and Cherokee Citizenship Timeline, 1787-1827

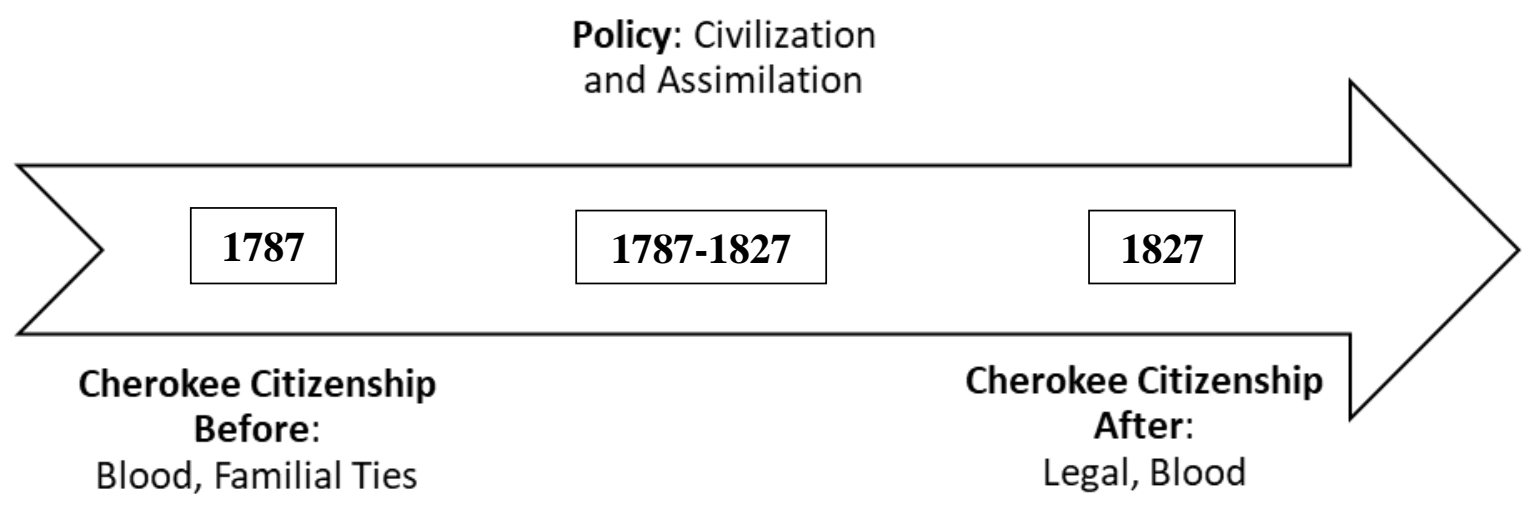


US officials, during the era of peace policy, altered Cherokee citizenship in a hugely significant way by forcing the Cherokee, through the Treaty of 1866 , to admit their freedmen as full and equal citizens. Cherokee citizenship changed from including all Cherokee by blood to including all Cherokee by blood and freedmen. This was done by the US in an effort to ensure that the freedmen were taken care of, and that the freedmen would not have to be the responsibility of any US state or the federal government (Littlefield 1978, 21-22). The Cherokee were greatly divided on the subject at the time, and remain so to this day (Sturm 2002). The move by the US displays both a lack of understanding of Cherokee political thought—what citizenship meant to the Cherokeeand the imposition of American political values upon the Cherokee government.

Figure 3.2 shows how the congressional policies of removal, peace, and assimilation influenced Cherokee citizenship. Removal strengthened the resolve of many Cherokee to reform their government in what would ultimately become Oklahoma and reinforce their constitutionally defined citizenship. When the Cherokee remade their constitution in 1839 , after removal, their definition of citizenship was virtually the same as it had been pre-removal. After the Civil War, however, the US treated the Cherokee like conquered peoples in need of peace terms. Those peace terms, outlined in the Treaty of 1866, redefined Cherokee citizenship to include freedmen. While the US saw this move as the alteration of a legal concept—something the United States was in the process of doing to correct the tragedy of slavery nation-wide — citizenship had always been more than a legal concept for the Cherokee. Changing tribal citizenship law also involved changing what it meant to be Cherokee. 


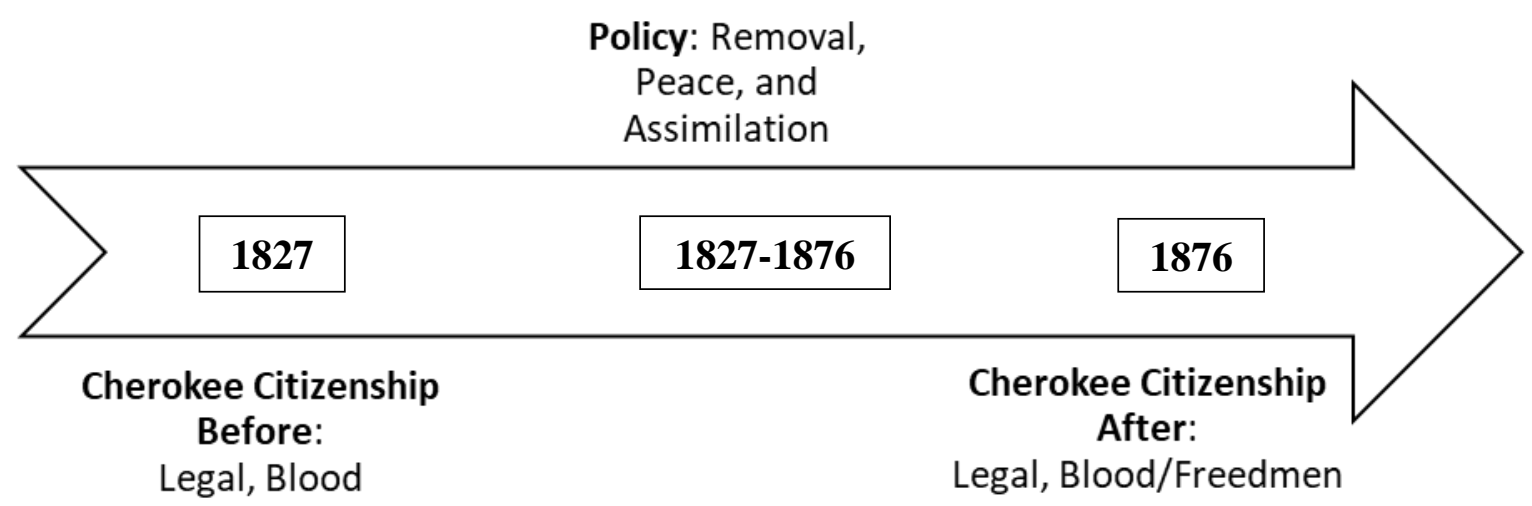

During allotment and termination, acts of Congress gradually reduced Cherokee citizenship to nothing. Pressure from railroad companies, interest groups, settlers and frontiersmen, and freedmen nudged Congress away from any semblance of co-existence toward a policy of total assimilation. This time, the Cherokee practice of holding lands in common was dismantled and all but the most trivial governing authority removed from the purview of their leaders. Figure 3.3 shows how the policy of allotment and termination erased the political value of Cherokee citizenship by dissolving the Cherokee Nation government. Individuals still belonged to their tribes. But governance was assumed by the United States and their appointed leaders. The Cherokee, however, did not lose their connection with one another during this time. The kinship bonds between families and society remained, in spite of US intervention. For the United States' part, Congress used the Dawes Rolls to determine Cherokee membership. 
Figure 3.3: Federal Policy and Cherokee Citizenship Timeline, 1877-1934

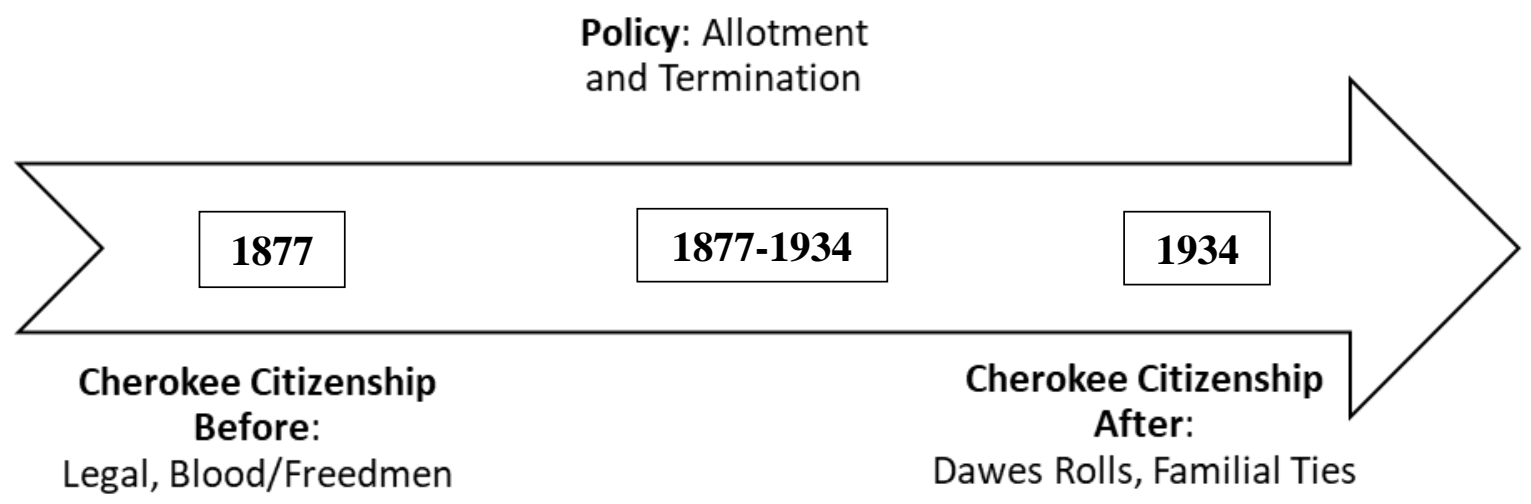

The Indian Reorganization Act, while it was intended to undo the ills caused by allotment and termination, did not change the status of Cherokee citizenship; nor did the termination and relocation policies of the 1950s. The Cherokees, since the deconstruction of the Cherokee Nation in 1907, remained much as they were-still belonging to the Cherokee tribe, but lacking the same legal citizen status they once had as members of a sovereign nation. The way that Congress viewed Cherokee citizenship, however, did change. During allotment and termination, Congress had reaffirmed their earlier decision, through legislation, that Cherokee membership in the tribe was inferior to American citizenship. By granting the Cherokee legal US citizenship after the Cherokee Nation was dissolved, Congress hoped to put the issue to rest once and for all. Yet Cherokee tribal membership and belonging retained its value to the Cherokee themselves. Ideologically, Congress had no answer to that. In the 1930s, Congress tried to give the Cherokee and other tribes back some of the governing authority they clearly still valued and desired. 
During the 1950s, Congress tried to stamp out the vestiges of tribal membership through relocation.

Finally, self-determination arose out of the social tumults in the 1960s, and led to the reestablishment of tribal governments and a new Cherokee Constitution. Because tribal kinship communities would not break up, either on their own or by force, Congress found it expedient to heed humanitarian calls for helping Indian society reclaim some measure of political and economic self-sufficiency. The emphasis was placed on creating opportunities for Indians to "participate in decision-making processes" that affected their lives (Gross 1989, 34). Figure 3.4 illustrates how the policy of self-determination ultimately allowed the Cherokee to recreate their constitutional government and again legally define Cherokee citizenship. In the new Cherokee Constitution, individuals wishing to obtain citizenship had to prove their relation to someone listed on the federal Dawes Rolls, compiled in the 1900s. Congress had fundamentally changed the dynamic way that the Cherokee qualified their legal citizenship—since the 1970s, Cherokee legal citizenship has been based on rolls conducted by the federal government.

Throughout the history of congressional treatment of the Cherokee, one view of Cherokee citizenship has always remained prominent: its inferiority to United States' citizenship. While Congress has gone through periods of alternating strictness and leniency toward the Cherokee, to put it mildly, the idea that Cherokee citizenship is not and cannot be more meaningful than US citizenship has remained constant. Congress has also taken issue with the blood requirement for citizenship in that the practice was difficult to understand or quantify. Due to the mixing of races, many Cherokee over time did not look Cherokee to racially and color-biased government officials. The Cherokee 
themselves struggled with determining Cherokeeness by blood after contact with white civilization (Littlefield 1978; Sturm 2002). Congress, by amending Cherokee citizenship first to include freedmen and second by profiling via the Dawes Commission, attempted to mold the Cherokee practice into one that resembled and could be better understood by American society.

Figure 3.4: Federal Policy and Cherokee Citizenship Timeline, 1934-2019

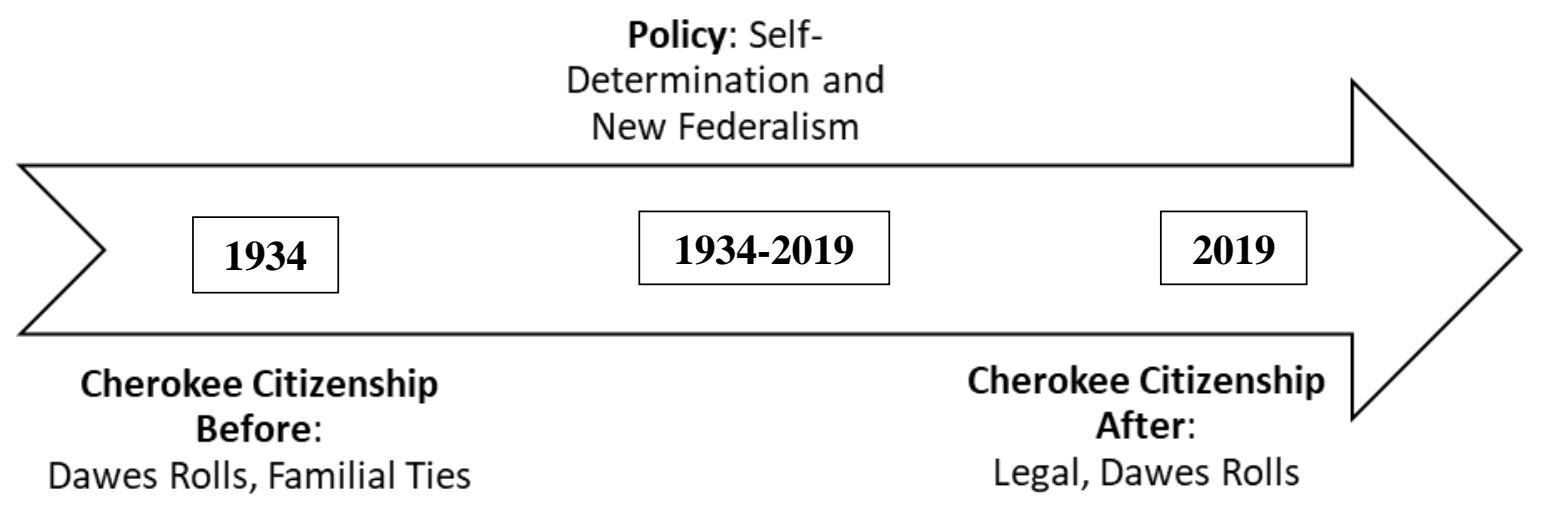

\section{A Summary of Federal Indian Policy}

The combined efforts of political actors in all three major American institutions resulted in different Indian policies in different eras. The political reality for many indigenous peoples under these regimes has been a rollercoaster of validation and repression. In some eras, like the first - civilization and assimilation — native peoples were given more space to freely conduct their affairs as they saw fit. In other eras, like the sixth — assimilation and termination-Congress completely took away all tribal authority from the Indians. The overall trend is one of uncertainty. 
Scholars have offered several explanations for the ups and downs, so to speak, of federal Indian policy (Duthu 2008, xxix-xxx). Some have argued that racial prejudice or other entrenched biases have influenced the unstable nature of Indian policy and tribal legal status (Bradley and Seton 2005; Williams 2005). Steven Curry has alternately argued that the US has resisted admitting and encouraging tribal sovereignty out of a desire to preserve political dominance (2004). Federal Indian policy has been muddled and unclear over time as a result of the struggle over whether to embrace the existence of other independent nations within US borders. Others have argued that traditional tribal beliefs and practices are simply incompatible with the idea of a sovereign nation (Alfred 1999). Tribes cannot be sovereign nations, because they were not set up to ever be, and therefore cannot become sovereign nations without destroying what they once were (Alfred 1999).

My argument is that racial prejudice, acquisitiveness, and ideological incongruence have been responsible for federal Indian policy in general—specific era policies depend on the individual political actors within each institution and how they deal with Cherokee political thought. Racial prejudice and acquisitiveness have changed with public opinion and American culture, yet the illiberalism endemic to indigenous governments has always been incompatible with US liberalism. In the next chapter, I conduct three case studies on Congress, the Presidency, and the Supreme Court to assess whether political actors understood there to be a Cherokee political thought and, if so, how they chose to ameliorate the tensions between that thought and American politics. 


\section{Chapter 4: American Institutions and Cherokee Political Thought}

It is not controversial to say that the United States' treatment of indigenous peoples has historically failed to live up to the promise made in the Declaration of Independence that "all men are created equal" and endowed with rights. The three major American political institutions, Congress, the Presidency, and the Supreme Court, were formed by and evolved under the direction of officials who, more often than not, exhibited either a distrust, misunderstanding, or hatred of the American Indian. Predominant explanations for this are American acquisitiveness and racial prejudice (Kettner 1978; Smith 1997; French 2016). Yet American greed and racism alone do not account for why Cherokee citizenship exists as it does today. I argue that the tensions between American and Cherokee political thought have ultimately caused US institutions to shape Cherokee citizenship over time.

Political scientists have not yet produced a study analyzing how American and Cherokee political thought are in tension with one another and how that tension manifests itself in political reality. That absence means that studies of federal Indian policy and how US institutions have influenced the Cherokee government have not been used to inform scholarly work on Cherokee citizenship. As such, the full picture of Cherokee citizenship — one that takes into account both American prejudice and ideological incongruence-remains obscured behind US policy failures. I contribute to political science literature by arguing that the ideological tension between American and Cherokee political thought has been a driving force behind why American institutions have pressed the Cherokee to change their definitions of citizenship. 
This chapter contains three institutional case studies - first Congress, then the Presidency, then the Supreme Court. In each study, I analyze whether there are tensions between American and Cherokee political thought found in official arguments. First, I present a theory of why Congress has pushed back against Cherokee political thought. Using speeches delivered in the Senate during the $21^{\text {st }}$ Congress, the first Congress of the Jacksonian period, I analyze pro-removal and anti-removal arguments to see whether the senators involved understood the United States to be in ideological tension with the Cherokee Nation. Second, I analyze speeches given by President Jackson to see whether his official arguments were driven by an understanding of a tension between Cherokee and American political thought. Finally, I take a key Supreme Court decision on the Cherokee, Worcester v. Georgia (1832), and analyze both majority and concurring opinions to see whether those justices understood there to be a Cherokee political thought at all and, if so, whether they believed Cherokee politics ideologically incongruent with American politics.

My goal is to tap into the common ideological current running through each institution - American political thought — and find ways to identify whether institutional actors recognize the existence of a Cherokee political thought and understand that to be in conflict with American political thought. The early 1830s offer a perfect case study for this effort. During the 1830s, all three branches of the federal government openly argued, both internally and externally, over Indian Removal and Cherokee sovereignty. This situation presents the perfect opportunity to gauge the merits of each argument as they portend an understanding or acknowledgement of Cherokee political thought. ${ }^{80}$

\footnotetext{
${ }^{80} \mathrm{I}$ analyze in detail the concept of Cherokee political thought, better understood as a package of dynamic ideas, in chapter two of this dissertation. This chapter builds off of that analysis.
} 


\section{Institutional Case Studies}

In 2007, Representative Diane Watson (D-CA) introduced a bill designed to sever United States' financial ties with the Cherokee Nation. ${ }^{81}$ Watson's move was prompted by a March 2007 amendment to the Cherokee Constitution that restricted citizenship rights to only those who could prove Cherokee ancestry by way of relation to someone listed on the Dawes Rolls. ${ }^{82}$ The result of that amendment was the effective disenfranchisement of descendants of formerly enslaved peoples once held by the Cherokee before 1866, called freedmen. On the surface, the Cherokee amendment and Representative Watson's bill appear to reflect a racial dispute. However, a more thorough analysis of the situation, and the development of the ideas underpinning it, reveals a complicated conflict between American and Cherokee political thought.

Congress has played a unique role in the development of Cherokee citizenship and deserves the most attention. Through the expansion of sovereignty policies dealing with relations between the US and Cherokee people, Congress has pushed back against Cherokee ancestral traditions that ostensibly conflict with the political values Congress is bound to uphold. Over time, as Congress has changed, sovereignty policies concerning the Cherokee and have emphasized the curtailment of different aspects of their ancestral political tradition. Today, the Cherokee and Congress, despite a reigning policy of native cultural preservation, remain at odds with one another. The tension is especially clear over the issue of Cherokee tribal citizenship.

\footnotetext{
${ }^{81}$ A Bill to Sever United States' Government Relations with the Cherokee Nation of Oklahoma, HR 2824, $110^{\text {th }}$ Cong., $1^{\text {st }}$ sess., Congressional Record 153, no. 147, daily ed. [October 1, 2007]: H 11053.

82 To prove citizenship through blood ancestry, the Cherokee Nation defers to those individuals and their families listed on the Dawes Rolls, which included people living in the Cherokee Nation during the 1898-1907 enrollment period. See Littlefield (1978) for a more detailed look at the Dawes Commission and how US agents categorized the Cherokee people.
} 
Recent scholarship on the development of Congress has emphasized electoral systems (Dow 2017), voting methods (Lapinski 2013), and overall congressional performance (Mayhew 2017), but has not paid enough attention to how Congress has understood the tensions between American and Cherokee political thought. This subject is important because of how it illuminates both the broader American contribution to the concept of citizenship and how tribal citizenship developed as a result. I contribute to this discussion by implementing a new interpretive framework to show how the liberal tradition in Congress has shaped Cherokee sovereignty and, by extension, tribal citizenship.

Congress is constrained, both by the nature of the institution itself and by American understandings of native peoples. That understanding is often clouded by the tension between American and Cherokee political thought. To unpack this relationship, I analyze speeches found in the Register of Debates made in the Senate during the $21^{\text {st }}$ Congress. Congressional debates, supplemented by considerations of national party platforms, serve as a proxy for the national mood, due to the nature of representation in that institution (Mayhew 2004). The added commitment to liberalism and refining public opinion makes congressional debates an especially useful way to observe American political sentiments.

As Rep. Watson's proposed bill suggests, the issue of citizenship for indigenous peoples in the United States is far from settled. As recently as 2017, the Cherokee have pleaded their case in federal courts for the ability to determine their own citizenship laws. Understanding how Congress has viewed the tensions between American and Cherokee political thought illuminates current debates that affect the lives of those living in Indian 
Territory today. As the United States continues to diversify, understanding the nuance in non-liberal traditions may help further dialogue and increase the instance of culturally sensitive policy decisions.

My goal in this section is to both challenge the primacy placed on American citizenship when treating Congress and Native American politics and create a new framework for studying how Congress has understood Cherokee political thought. Because US citizenship currently carries such weight internationally — and due to the edifying societal benefits, such as communal acceptance, that may come from acquiring legal membership — scholars have placed utmost importance on the acquisition of US citizenship when discussing indigenous peoples (Kettner 1978; Fixico 1986; Gross 1989; Hoxie 1989; Smith 1997). These pieces, however, often either gloss over or omit the intrinsic value of tribal citizenship for native communities, as well as the tensions between the ancestral and western political traditions. While there have been studies of congressional policies, like Lapinski (2013), that have included Indian policies, these too have omitted how Congress has wrestled with Cherokee political thought.

A focus on tribal citizenship and analyzing how Congress has viewed Cherokee political thought are important for both theoretical and practical reasons. By glossing over tribal citizenship, understood as a product of Cherokee political thought, scholars risk losing critical nuance in the ongoing debate between how the United States and the Cherokee Nation should coexist. At stake is the status quo of social unease when discussing tribal issues, as exhibited by the Sen. Warren DNA test. ${ }^{83}$ A clearer understanding of what tribal citizenship is and how it differs in importance for native

\footnotetext{
${ }^{83}$ Cillizza, "Elizabeth Warren Might Have Actually Made Things Worse with Her DNA Gambit," CNN Politics.
} 
peoples may alleviate some of the confusion for Americans perplexed at the political difficulty of declaring oneself to be Cherokee through DNA test. Practically, by altering the way scholars understand Congress to deal with Indian matters, the way US institutions digest non-liberal political traditions may become clearer-better policies might be made that alleviate real-world problems that affect millions of indigenous peoples in the US (Taylor 1983; Kymlicka 1995).

\section{Congress, American Political Thought, and Tribal Citizenship}

Congress is founded upon a pre-dominantly liberal-republican understanding of society. ${ }^{84}$ Liberal society is based on the consent of the governed and dedicated to the protection of natural, individual rights. ${ }^{85}$ Republican society is geared toward the cultivation of civic virtue and the public good. During the American Revolution, widespread agreement existed on the proper liberal ends of government — to "protect people in their lives, liberty, and property" (McDonald 1985, 1). Many also took for granted that these ends could best be obtained via a republican government (McDonald 1985, 4-5).

\footnotetext{
${ }^{84}$ Rogers Smith's challenge to this liberal-republican founding theory suggests that the United States, rather than being founded upon strict liberal or republican ideas, was founded on a mixture of multiple political traditions, some liberal or republican and others illiberal or even anti-republican (1997).

${ }^{85}$ Liberal thought in America was developed from the writings of Sydney, Locke, and Montesquieu, among others (Dow 2017, 28). Liberalism for these authors emphasized government by consent among co-equal individuals and the protection of individual rights. Furthermore, the liberal tradition taught that equality of individuals and the existence of innate rights were derived from the natural law, which flows from a divine creator (West 2017, 85-86). In the Lockean account, human beings are God's workmanship; they are therefore at liberty to order their actions in accordance with the natural law or act contrary to justice (Locke II 5. 1-20, 6. 1-25). The natural law binds men, all created equal, to preserve their lives and "the rest of mankind" (Locke II 6. 19-24).

According to the Lockean liberal tradition, individuals enter into society for the enjoyment of their properties in peace and safety; the great instrument of their enjoyment is the law established by the legislative power, whose rules must always comport with the natural law (Locke XI 134.1-10). Since natural law, according to Locke, mandates the preservation of the human person, the legislative power, therefore, is limited to the public good, having no other end but the preservation of human life and happiness-which is the protection of their rights (Locke XI 135. 15-23).
} 
The practical compatibility of these two concepts was not immediately evident, as demonstrated by the inadequacy of the Articles of Confederation. Combined with a more thorough consideration of what Hamilton called "the practical business of government," however, liberalism and republicanism formed the basis for the institution of Congress. ${ }^{86}$ The reason liberalism and republicanism are often considered in tension is due to their sometimes-conflicting commitments. Both concepts privilege the individual and celebrate their place in the political process (Dow 2017, 25). Yet they are in tension because imperfect humans may govern in a way that threatens liberal values - the "public good 'discovered' by representatives may demand the abrogation of citizens' basic rights" (Dow 2017, 25). Limited liberal government, therefore, stood in tension with the Founders' adherence to Aristotle's argument that "a state exists for the sake of the good life, and not for the sake of life only...political society exists for the sake of noble actions," not mere companionship (Ketcham 1993, 47).

The Framers, however, believed that something akin to a mixed constitutional regime could ultimately resolve those tensions. They crafted a regime wholly unique, one that did not fit into classical definitions of republican, yet still adhered to the core republican principle that society existed for the public good (McDonald 1985, 285-287). The public good often held in mind consisted of the maintenance of liberal values. These values would be upheld by a synthetic government, with different components organized to achieve desired outcomes (Dow 2017, 26). The result, however, was not always the

86 "Continentalist No. I," July 12, 1781, in The Papers of Alexander Hamilton, ed. Harold C. Syrett et al., 26 vols. (New York, 1961-1979), 2: 649-650. 
practical application of liberal or republican values, at least not for everyone (Kettner 1978; Smith 1997). ${ }^{87}$

Congress has the authority to determine requirements for United States' citizenship. "Explicitly or implicitly_by constitutional provision, legislative enactment, or mere exercise of power_-" the US government "assumed sovereign control" over naturalization and the admittance of foreigners into the polity (Kettner 1978, 214). Since the early republic, Americans harbored a sense of citizenship, based on individual consent, which entitled one to fundamental privileges and immunities as articulated in the law (Kettner 1978, 287). These beliefs influenced the passage of the first citizenship laws at both national and state levels (West 2017). While membership in the American republic writ large could be acquired automatically, it was presumed that true Americans would be raised from birth educated in the "fundamental values necessary for selfgovernment"- a love of liberty (Kettner 1978, 287-288). Americans assumed that natural born meant birth within the allegiance, conferred status with accompanying rights. There were, however, several contradictions in the law and in popular thinking when it came to citizenship (Smith 1997).

The primary contradiction in American citizenship was that it was used negatively to distinguish between those not only abroad, but also at home (Kettner 1978; Shklar 1991). The valued principle of birthright citizenship clashed with the prejudice many Americans felt toward blacks as well as Indians. For the sake of legal and theoretical consistency, either principle or prejudice needed to prevail. The outbreak of the Civil

\footnotetext{
${ }^{87}$ While "one might well argue that American political thought possesses both unity and distinctiveness to an extent rarely, if ever, seen in human history" (Seagrave 2015, 2), this has not prevented extreme ideological incongruence over how to understand the American Indian or their conceptions of the political.
} 
War, according to Kettner, "removed obstacles that had long prevented Americans from achieving a consistent concept of citizenship" $(1978,334) .{ }^{88}$ Through force, the United States decided that the principle of birthright citizenship was to be the law and that state citizenship was inherently subordinate to American citizenship. By the end of the Civil War, the Union was galvanized in its decision that the United States was not a "political community formed of separate sovereign peoples," it strove to make uniform citizenship laws within the boundaries of the nation (Kettner 1978, 334).

While liberal citizenship at the Founding may have entailed a contract between heads of families, derived from a perceived naturally hierarchical order (Adams 1842), liberal citizenship in America today is more egalitarian in its emphasis on the individual, although illiberal elements remain (Huntington 2004; Dyer 2013). United States' citizenship at the Founding was reserved for propertied white men. Legal membership has since been extended to include virtually everyone living in America over the age of 18. The development of United States' citizenship, including how Congress has viewed legal citizenship over time, has been well-documented by Rogers Smith (1997), James Kettner (1978), and others (Shklar 1991; Collins 2006; Jones 2018). The story of Congress and citizenship has been one of an ideal version of citizenship — consent-based, granting political, leading to social (Shklar 1991), equality for all—muddled by political expedience. To expedite legislation, avoid partisan or sectional conflicts, or appease constituents, Congress has at various points in American history excluded blacks, women, soldiers, and indigenous peoples, among others, from full national citizenship.

\footnotetext{
${ }^{88}$ For a full treatment of the development of American citizenship from the colonial period to the end of the Civil War, see Kettner (1978). Kettner elaborates in detail on how the notion of individual consent and state citizenship was reconciled by force with the idea that United States' citizenship was primary and state citizenship secondary (1978). For an historical telling of the debate over sovereignty and citizenship during the Civil War, see Goodwin (2005).
} 
Due to the global power commanded by US citizenship, especially from the $20^{\text {th }}$ Century on (Shklar 1991), scholars have primarily focused on how Congress has excluded Native Americans from American citizenship (Fritz 1963; Prucha 1976; Fixico 1986; Gross 1989; Hoxie 1989; Smith 1997; French 2016). These works presume that American citizenship is of preeminent importance to the Native American. American citizenship, and the political representation that entails, is critically important to those living on American soil—especially since Congress makes so many decisions critical for the daily management of reservations and tribal governments (Taylor 1983).

Furthermore, being seen as a full American citizen has historically brought with it a measure of societal acceptance, important for peoples maligned for the color of their skin, their spirituality, or their ethnic heritage (Taylor 1980; Shklar 1991). What these scholarly works often either miss or gloss over, however, is the importance of tribal citizenship to indigenous peoples.

Congress has not just influenced how and when indigenous peoples came to be United States' citizens, it has also influenced how indigenous governments view themselves and their own citizenry. ${ }^{89}$ This influence was exhibited during different congresses with different overarching Indian policy goals (Prucha 1976). One of the most predominant goals of Congress has been the assimilation of the American Indian (Fritz 1963; Saltz 1975). Assimilation has largely meant the incorporation of indigenous peoples into American society, accomplished through education, trade, and Christianization efforts - the endgame was to make Indians into "acceptable American citizens" (Prucha 1976, 342). The pursuit of tribal assimilation has never fully waned, as

\footnotetext{
${ }^{89}$ The Washington Administration set the stage for this federal paternalism, by granting Congress the exclusive authority to regulate Indian Country in the 1783 Treaty of Hopewell (French 2016, 32).
} 
Rep. Watson's bill to extinguish federal funding for the Cherokee Nation suggests. Rep. Watson and others made it clear that if the Cherokee did not conform to the US interpretation of both the Treaty of 1866 and tribal citizenship, there would be serious financial consequences.

\section{A Theory of Congressional Behavior toward Cherokee Citizenship}

A Theory of how Congress understands and has understood Cherokee political thought must find a way to identify tensions between the Cherokee and American political thought within Congress. These tensions may be best exemplified within congressional debates. The previous section showed how Congress has affected Cherokee citizenship by analyzing their broad policy systems. But that does not explicitly reveal whether Congress actually wrestled with the tensions between American and Cherokee political thought. It could be that Congress was dismissively racist in its treatment of indigenous peoples or that they did not care to understand native politics. If Congress did wrestle with ideological tensions between the Cherokee and US, those arguments should come out in congressional debates and increase our understanding of how this complicated idea is handled.

Given Congress' liberal foundations, and the Cherokee commitment to their brand of ethnic republicanism, these two competing ideals should lead to clashes over certain central ideas, like citizenship. Table 4.1 provides a comparison between American and Cherokee political values with regard to Cherokee citizenship, as they existed in the 1820s and 30s. While American citizenship in those years was far from what we today might term liberal (Smith 1997), it was grounded in the notion that hereditary citizenship 
was archaic and had no place in a democratic society (Kettner 1978). Cherokee citizenship, by comparison, was solely based on lineage. Only those possessing Cherokee blood, and not even always then, could be considered a member of the community and a citizen (Sturm 2002, 52-57).

The United States and the Cherokee conceptions of land ownership were also fundamentally different. According to Thomas West, the American Founders' view of property, derived from the Lockean tradition, rested on a theory of justice and utility (2017, 312-313; McDonald 1985, 63-65). Property ownership was just because men have a natural right to the "fruits of their labor," being free, independent, and equal to one another (West 2017, 312). Property ownership was also useful to society and life more generally as it gave individuals a stake in caring for themselves and their families in a way that benefitted the whole (West 2017, 313). As such, property ownership was also seen as necessary for liberty and happiness — to avoid disputes, the Founders' policy was "to establish, as quickly as possible, unquestioned title to private ownership of land" (West 2017, 326). American liberalism required that government be the arbiter of demarcations and distinctions in all matters of land and other property ownership (McDonald 1985, 152-154).

The Cherokee understanding of land ownership — communally held lands (Conley 2005, 198) — was mystifying to European settlers and, eventually, Americans. Cherokee society rested upon an ordered, "egalitarian, inclusive, flexible, and decentralized" understanding of the family that was, traditionally, highly mobile in the physical sense (Stremlau 2011, 67). Their perceptions of "relatedness" were broad and made for closeknit communities (Stremlau 2011, 67; Sturm 2002, 33). Communally held lands 
facilitated that physical mobility and aided in maintaining a culture of broad familial ties (Stremlau 2011, 65-68). Upon establishment of a written constitution, the Cherokee opted for legal protections for communally held lands.

Table 4.1: A Comparison of American and Cherokee Political Values, 1827-1865

\begin{tabular}{|cc|}
\hline American Liberal & Cherokee Ancestral \\
\hline Removal of Hereditary Citizenship & Hereditary/Blood Citizenship \\
Individual Private Land Ownership & Communal Land Ownership \\
Gendered hierarchy & Ordered Society \\
\hline
\end{tabular}

In the early United States, there was evidence of a gendered hierarchy, where, despite efforts made to overcome traditional social class structuring, men and women had distinct societal roles (Adams 1842). Liberal citizenship at the Founding may have entailed a contract between heads of families, derived from a perceived naturally hierarchical order (Adams 1842). The ancestral tradition is not grounded in the idea of an association of rights-bearing free agents. The ancient Cherokee tradition, by contrast, was founded on a particular set of opinions and mores (Tocqueville 2000, 1.1.10, 305), that "operated according to principles of harmony and balance" (Brown 2014, 12). Men and women performed their own distinct social and political tasks, designed to complement one another. The Cherokee had a "specific and complicated system for positioning 
oneself in relationship to others [that] should not be confused with rank" (Stremlau 2011, 23). Cherokee clans provided "order rather than rank" (Stremlau 2011, 23).

These differences, along with others, have often made American culture and society mystifying for the Cherokee, and vice versa (Smithers 2015; Stremlau 2011; Minges 2003; Sturm 2002; Littlefield 1978; Kettner 1978). The fact that Congress has passed many pieces of legislation directly affecting the Cherokee and Cherokee citizenship, however, does not mean that differences in how politics is understood influenced their decisions. If the racially-based view of United States-Cherokee relations, as Rep. Watson suggested in 2007, is correct, then the tensions between American and Cherokee political thought do not matter as much as simple racial tension. If, however, those tensions do matter in the formation of congressional policies and legislation, then they should be made manifest in congressional debates over Indian policy.

Parsing through these distinctions is not a simple task. The first difficulty is finding a suitable starting point to begin the analysis. I have chosen to focus on the $21^{\text {st }}$ Congress, also known as the first Congress of the Jackson era. It was during these years that, in many ways, Congress wrestled for the first time with the differences between the United States and Native Peoples (Saltz 1975). Although Congress had passed legislation on US-Indian relations prior to this era, the great political push for Indian Removal forced Congress to seriously debate the legal and social standing of indigenous peoples. If there are indications that Congress took into consideration Cherokee political thought, we should find them in the debates over the various Indian Removal bills that circulated during the $21^{\text {st }}$ Congress. 
The second difficulty is one of definition. How may we determine if Congress takes into account a Cherokee view of politics or acknowledges Cherokee political thought or the ancestral political tradition? Focusing on the debates held in the Senate, I argue that Congress acknowledges the ancestral political tradition if senators attempt to wrestle with or define how the Cherokee understand politics as distinct from how members of Congress might understand American political thought. What this looks like is a member of Congress discussing a Cherokee political or cultural custom like those listed above, identifying it as originating from a different view of politics, and placing it in tension with American political thought. Dismissive statements, such as mentioning what some members of Congress might term savage or uncivilized practices, without identifying them as part of a distinct, non-liberal view of politics, would tend more to support Rep. Watson's contention that the disputes between Cherokee and the United States are predominantly racial in nature.

This analysis provides insight into the ways that members of Congress understood the tensions between indigenous peoples and the United States. The arguments put forth by the actors involved offer a look into the complexity of the issue not revealed in the final piece of legislation alone. I have selected the pivotal year of 1830, in which bitter debates took place in the Senate over the Jackson Administration's intention to remove eastern tribes west of the Mississippi, because it offers the best starting point for understanding the relationship between Congress and the Cherokee when thrust out into the open forum by external factors. Those external factors included the ratification of the Cherokee Constitution, the nation-wide popularity—especially in Georgia—of removal 
as a solution to the perceived Indian problem, and the Jackson-Democrat takeover of Congress.

\section{The $21^{\text {st }}$ Congress and the Tension between American and Cherokee Political Thought}

An analysis of the Indian Affairs debates in the Senate, from January to May 1830, reveals a plethora of internal divisions and alliances. In general, Senators from the North East - including Peleg Sprague (AJ-ME) and Nathan Sanford (AJ-NY) — were opposed to both the Jackson Administration and Indian Removal. ${ }^{90}$ Senators from the South-like the Chairman of the Committee on Indian Affairs, Hugh Lawson White (DTN), John Forsyth (D-GA), Edward Livingston (D-LA), and Thomas Benton (D-MO) tended to be either pro-Jackson, Democrats, and, especially in the case of Sen. Benton, pro-removal/westward expansion. ${ }^{91}$ Some Senators, like James Noble (AJ-IN), did not belong to the Jackson coalition yet were pro-removal. ${ }^{92}$ Among the Anti-Jackson coalition, there was no greater opponent of removal in the Senate than Theodore Frelinghuysen (AJ-NJ), who fought the hardest, and spoke the longest, against the proposal to remove the Cherokee and other eastern tribes from their homelands. These senators found themselves in 1830 caught between the attempts of Georgia to subjugate all indigenous peoples within their borders via legislation, the Jackson Administration's popular push for removal, and the new Cherokee Nation constitutional government, claiming independent sovereignty and a right to the land they had held since antiquity.

\footnotetext{
90 I use the acronym AJ throughout this dissertation to distinguish Senators who belonged to the Anti-Jackson coalition in Congress.

91 I use D to identify members of the Jacksonian-Democrat coalition, as well as modern-day Democrats, in this chapter.

${ }^{92}$ Register of Debates, Senate $21^{\text {st }}$ Cong., $1^{\text {st }}$ Sess., 19.
} 
The pro-removal arguments presented in the Senate were many, ranging from the disgust at the "disposition" that "considered the savage tribes in our territory and under our protection" to be "already civilized" held by Sen. Livingston (D-LA), who presented the Senate with many dismissive racial slurs when speaking of the Indian, ${ }^{93}$ to the more measured analysis of Sen. Forsyth (D-GA), who claimed a great stake in the situation as representative from Georgia. Here I focus on the two main questions posed by Sen. Forsyth. Forsyth's first argument began by questioning the right of the Cherokee to their homelands in Georgia, North Carolina, Alabama, and Tennessee. ${ }^{94} \mathrm{He}$ concluded that the Cherokee were not sovereign, as they had given any semblance of sovereignty away via treaty with the United States, and therefore had no legitimate claim to their lands in Georgia, or anywhere else, that was not subordinate to the will of a state or Congress. Forsyth's first question, whether the Cherokee had any right to remain on their lands, was predicated upon Cherokee sovereignty as understood by treaty negotiation. Whatever sovereignty the Cherokee possessed before signing treaties with Georgia and then the United States was washed away with the Treaty of Hopewell in 1787, which states that "The United States give peace to all Cherokees, and receive them into their favor and protection;' strange words to be used [toward] an unconquered and independent" nation. ${ }^{95}$ Forsyth, by referencing the Treaty of Hopewell, suggested that, since "legislation is the highest act of sovereignty," the Cherokee granting Congress the right to legislate for them constitutes an abdication of sovereignty. ${ }^{96}$ Furthermore, Forsyth argued, "the United States obtained, by treaty, the power to legislate over the

\footnotetext{
${ }^{93} \mathrm{Ibid}, 18$.

${ }^{94} \mathrm{Ibid}, 325-339$.

${ }^{95}$ Register of Debates, Senate $21^{\text {st }}$ Cong., $1^{\text {st }}$ Sess., 326.

${ }^{96} \mathrm{lbid}, 326$.
} 
Cherokee, and transferred it to Georgia" when Congress gave Georgia specific geographical boundaries in $1802 .{ }^{97}$ The Cherokee, therefore, had no right to occupy land granted to Georgia and had no sovereign ability to resist Georgia's incorporation of all Indians under Georgia law. The Cherokee Constitution represented a blatant attempt to erect a new state within the jurisdiction of another state, something that cannot occur "without the consent of the Legislatures of the States concerned," as stated in the US Constitution. $^{98}$

In the course of asking and answering his first question, Forsyth revealed a complete and utter disregard for the value of Cherokee citizenship. Since he saw the Cherokee as having given up all legitimate claims to sovereignty, the "intrusive sovereignty of a petty tribe of Indians" could not carry actual political weight. ${ }^{99}$ Additionally, Forsyth merely granted passing sovereignty to the Cherokee and concluded that "European discoverers, particularly the English," had long since by right of discovery or conquest exercised legitimate sovereignty over the Indian tribes in America ${ }^{100}$ Exercising the right of sovereignty over indigenous tribes was part of discoverers' "Christian duty." ${ }^{101}$ Forsyth, by this response, does not appear to comprehend a non-liberal Cherokee political thought, as his statements do not reveal a difference in how land ownership was understood by Europeans and the Cherokee. There is no indication in Forsyth's arguments that he grasped the Cherokee concept of holding lands in common for the good of society—if he did, Forsyth either gave no indication or deliberately omitted that information.

\footnotetext{
$97 \mathrm{lbid}, 326$.

${ }^{98} \mathrm{lbid}, 332$.

${ }^{99}$ Register of Debates, Senate $21^{\text {st }}$ Cong., $1^{\text {st }}$ Sess., 332.

$100 \mathrm{Ibid}, 333$.

101 Ibid, 333.
} 
Forsyth also asked the Senate what justice looked like for the Cherokee. "I feel," Forsyth lamented, "and have ever felt the strongest anxiety to do justice to the Indian tribes." 102 The Senator from Georgia argued that his goal, and the goal of removal, was to create a place safe from the inevitable and constant incursions of white civilization into Cherokee territory, incursions that brought nothing but death and decay to the Cherokee. Removal would provide safe lands west for Indians to live in, where they might continue to unmolested. "Our opinions" on "the aborigines were not formed to suit our interests," Forsyth explained; "The condition of the remnants of the once formidable tribes of Indians is known to be deplorable... all desire to grant more than is justly due for their preservation and civilization." 103 Justice for the Cherokee, in Forsyth's view, entails the continued efforts at civilizing them far removed from the neighborhood of white government and state sovereignty.

Forsyth's answer to his second question, that justice requires removal and continued civilization efforts, is based on a particular supposition about Cherokee political thought. This supposition is grounded in the dehumanizing idea that the Cherokee people are "useless and burthensome" and troublesome to the state of Georgia and the US as they are. ${ }^{104}$ The Georgia senator commented at one point that he did "not believe that this removal [would] accelerate the civilization of the tribes. You might as reasonably expect that wild animals, incapable of being tamed in a park, would be domesticated by turning them loose in the forest." ${ }^{\prime 05}$ Forsyth's racially condescending tone is clear-the Cherokee deserve little better than animals in his view, yet the

\footnotetext{
102 Ibid, 327.

103 Ibid, 326.

${ }^{104}$ Register of Debates, Senate $21^{\text {st }}$ Cong., $1^{\text {st }}$ Sess., 328.

105 Ibid, 327.
} 
benevolent United States grants them more than they deserve. But while displaying extreme racial prejudice, does Forsyth's argument hinge also on an understanding of the tensions between American and Cherokee political thought?

Justice for the Cherokee, according to Forsyth, hinged on both the subhuman status of the Cherokee people and their inferior form of government, derived from the sham of Cherokee political thought. The senator from Georgia argued that the "desirable end" of civilizing the Indian "cannot be obtained without destroying the tribal character, and subjecting the Indians, as individuals, to regular action well digested laws." ${ }^{106}$ Here, the tribal character-implicitly referring to the communal, rather than individualistic, nature of Cherokee society - is displayed as in tension with the American way of life. Cherokee political thought, Forsyth contended, as made manifest in their constitutional government, was the trick of special interest groups, funded by northerners. "The Cherokee government," Forsyth said, "is in the hands of a few half-breeds and white men, who, through its instrumentality, regulate the affairs and control all the funds of the tribe...not five hundred of whom can read or write!" ${ }^{107}$ Forsyth thought the Cherokee government a sham — not the product of a system of political thought, but the result of a few dedicated elites presiding over a frail population. "Their government is of no consequence," Forsyth concluded, "except as it operates to improve their conditionmoral, physical, and intellectual." 108

While Forsyth hinted at the existence of an operative Cherokee political thought in tension with American political thought, the senator ultimately denied its existence and legitimacy. By presenting the Cherokee people as subhuman, governed by a few elites

\footnotetext{
${ }^{106}$ Ibid, 327.

${ }^{107}$ Register of Debates, Senate $21^{\text {st }}$ Cong., $1^{\text {st }}$ Sess., 329.

108 Ibid, 339.
} 
who were not even really Cherokee, Forsyth denied the legitimacy of a Cherokee political thought. He instead opted to discredit the founders of the Cherokee government by saying that their political innovations did not originate from the tribe at all. Forsyth did state that the "tribal character" must necessarily be wiped out by civilization, suggesting that there is a fundamental political tension that cannot be resolved. ${ }^{109}$ This suggestion, however, was presented without analysis on his part or a discussion of what that tension might entail—Forsyth certainly did not contemplate aloud any amelioration for said tension. Forsyth's primary opponent in the Senate, Theodore Frelinghuysen (AJ-NJ), thought otherwise.

The thrust of anti-removal sentiment in the Senate is best understood through an analysis of Sen. Frelinghuysen's arguments, supplemented by remarks his antiadministration colleagues. Sen. Frelinghuysen, like Sen. Forsyth, presented the Senate with the same two questions. The first question was whether the Cherokee had any right to remain on their lands. Frelinghuysen answered that they did have the right to remain. This was true for three main reasons. The first reason was because "God, in his providence, planted these tribes on this western continent" before European powers had their existence—divine judgement willed it so. ${ }^{110}$ The second reason was that the Cherokee people had always been nations, "far behind us indeed in civilization, but we still respected their forms of government" in all US dealings with them. ${ }^{111}$ The third reason was that, in the Treaty of Hopewell (1787), the Cherokee "had a boundary assigned them" under the protection of the United States. ${ }^{112}$ The divine will, the inherent

\footnotetext{
109 Ibid, 327.

${ }^{110}$ Register of Debates, Senate $21^{\text {st }}$ Cong., $1^{\text {st }}$ Sess., 311.

111 Ibid, 312.

$112 \mathrm{Ibid}, 310$.
} 
sovereignty of the Cherokee upon first contact, and legal contract with the United States all prevented the forced removal of the Cherokee people by the same US government.

Frelinghuysen's argument for why the Cherokee ought to, by right, remain in their ancestral homelands rests on the supposition that the Cherokee people possess a certain legitimating dignity that translated into a viable form of sovereign government. In that sense, the Cherokee "have nothing to do with State sovereignty, or United States, sovereignty. They are above and beyond both." ${ }^{113}$ In fact, Frelinghuysen argued, contra Forsyth, that sovereignty and level of civilization are two unrelated concepts- the uncivilized race of the Cherokee still possessed "unquestioned political sovereignty" in their form of government. ${ }^{114}$ This claim supported the idea that a viable system of political thought could originate from a people, regardless of technological or perceived cultural advancement. Frelinghuysen's answer to the second question, one the nature of justice for the Cherokee, also differed significantly from Forsyth's.

What course of action by Congress would constitute justice for the Cherokee people? Frelinghuysen answered that a proper view of their humanity with respect to their progress toward civilization gave Congress and the United States cause to support the Cherokee in their new government built in their ancestral homelands. As the Cherokee approached Americanization, the more worthy they were of having their rights defended. ${ }^{115}$ The Cherokee already had an assembly, where "they deliberate[d] and weigh[ed] the policy of measures...these councils embod[ied] the collected wisdom of the tribes. Their influence [was] of the authority of law." 116 Prior generations had found

\footnotetext{
113 Ibid, 312.

114 Ibid, 313.

${ }^{115}$ Register of Debates, Senate $21^{\text {st }}$ Cong., $1^{\text {st }}$ Sess., 310.

116 Ibid, 311.
} 
the Cherokee "exercising all the rights, and enjoying the privileges, of free and independent sovereigns of this new world," not living like lawless barbarians - their government was "patriarchal in its character, and energetic in its influence." 117 The policy of civilization, right and just, moved the Cherokee closer toward civilization, which ought to have, according to Frelinghuysen, made their claims to sovereignty even greater. Implicit in Frelinghuysen's treatment of justice for the Cherokee is the understanding that while the Cherokee had value as a people before, their obvious progress toward Americanization made them even more favorable and important. It is unclear from Frelinghuysen's argument whether a Cherokee political thought—distinct from American political thought — could be viable. The senator from New Jersey did, however, acknowledge the political development of the Cherokee government and the inherent humanity of the Cherokee people themselves. Frelinghuysen did hint at the existence of a Cherokee political thought, but seemed to believe that the Cherokee would ultimately Americanize to the point of shedding ancestral political traditions-which were left largely unmentioned by the senator. Frelinghuysen understood the Cherokee to possess an equal share in human dignity, while at the same time acknowledging that the policy of civilization was right and just — the Cherokee needed to continue changing as they had been.

The individuals who in large part set the tone in the Senate for the debate over Indian removal framed the question of Cherokee right and justice in distinct ways and provide insight into how Congress during that time understood the tension between American and Cherokee political thought. Sen. Forsyth, an ardent proponent of removal, acknowledged a distinct Cherokee vision of politics and proclaimed that vision

${ }^{117}$ Ibid, 312. 
incompatible with American politics. Forsyth's position was grounded in a prejudiced view of the Indian person, whom the senator characterized as subhuman. Sen.

Frelinghuysen, on the other hand, also acknowledged a Cherokee vision of politics distinct from the American ideal. The Cherokee vision of politics, for Frelinghuysen, was also inferior, yet the New Jersey senator's view was founded upon a much more positive and affirming view of the Cherokee person. Frelinghuysen claimed that the Cherokee, as equals, were capable of their own great civilization, especially since the senator was convinced that the Cherokee would eventually progress toward total emulation of the American polity.

A view of the Indian person was one of the primary divisions between the pro and anti-removal factions in the Senate during the $21^{\text {st }}$ Congress. Those who argued for removal tended to see the Indian as either subhuman or incapable of coexisting peacefully with white civilization. Forsyth and Frelinghuysen were not alone in their respective opinions. Other pro-removal senators also displayed a tendency to dehumanize the Cherokee-Senators White (D-TN), Hendricks (AJ-IN), and Livingston (D-LA) all referred often to the savage simplicity of the Indian. ${ }^{118}$ Conversely, Frelinghuysen's allies - Senators Sanford (AJ-NY) and Sprague (AJ-ME), among others—concerned themselves with the injustices done to the Cherokee, while inferior in government, the arts, and culture, were equal in human dignity. ${ }^{119}$ The pro-removal arguments of Senators Livingston and Forsyth reveal an understanding that tribal government is fundamentally incompatible with the republican government guaranteed by the United States Constitution. Their solution, however, was tinged with an aggressive form of racism.

${ }_{118}^{118}$ Register of Debates, Senate $21^{\text {st }}$ Cong., $1^{\text {st }}$ Sess., $16 ; 18$.

$119 \mathrm{lbid}, 7 ; 16$. 
Senators like Frelinghuysen and Sanford, who were against removal, couched their arguments in an understanding that, while tribal government was incompatible with American political thought, the Cherokee possessed the capacity, as equal human beings, to approach model self-governance in the vein of white Christian America.

\section{The Presidency and Cherokee Citizenship}

While Congress has been primarily responsible for a lot of federal Indian policy, United States Presidents have also had their own unique relationship with indigenous peoples. The nature of the office of the chief executive has brought presidents into direct confrontation with the several Indian tribes for a host of reasons including open war, westward expansion, civilizing the continent, frontier settlement, and the consolidation of US sovereign authority over American territory. This relationship has changed over the course of political time. Yet while the institution of the presidency has changed, and individual presidents differ from one another, there are noticeable trends in the ways in which presidents have treated and talked about indigenous peoples. In this section, I identify, analyze, and interpret these trends, in order to create a new theoretical framework for studying how the presidency has affected Cherokee citizenship.

In the previous section, I examined how scholars might find examples of ideological incongruence between the Cherokee and Congress; in this section, I do the same with the Presidency. Scholars have written at length about the institution of the

presidency-its creation (Thach 1969), how it developed (Tulis 1987), how it can yield scientific inferences (King 1993; Skowronek 2008), its characteristics (Neustadt 1990), and even its relationship to federal Indian policy (Trafzer 2009). I add to this 
conversation an analysis of how presidents have written about indigenous politics (a proxy for Cherokee political thought) to understand how that American institution has shaped Cherokee politics, and thereby, Cherokee citizenship.

How may scholars identify an ideological incongruence between the Presidency and indigenous peoples? In this section, I present an analysis of presidential State of the Union (SOTU) addresses to Congress. ${ }^{120}$ If Presidents have identified a distinct indigenous political thought, and tensions between American and Cherokee political thought, those tensions should be evident in the major annual addresses to Congress. ${ }^{121}$ State of the Union addresses are also useful for revealing general Indian policy, salience of Indian issues, and a timeline of US-Indigenous relations. Second, I analyze presidential rhetoric during the 1820s and 1830s to see whether Andrew Jackson recognized a tension between American and Cherokee political thought during those pivotal years in both United States and Cherokee history. In the next section, I break down the role of the president in dealing with Indigenous peoples before turning to an analysis of presidential Indian policy.

\section{The Great Father: Presidents and Indigenous Peoples}

The President, as both commander in chief of the military and vested with treatymaking authority, has been especially concerned with the status of indigenous peoples since the Washington Administration. Brutal warfare and a severe clash of cultures colored the relationship between the President and Indian tribes from the beginning, as

\footnotetext{
${ }^{120}$ Sometimes referred to as Annual Messages to Congress.

${ }^{121}$ Donna Hoffman and Alison Howard, in their study of State of the Union addresses over time, argue that Presidents, even before the advent of the modern Presidency with FDR, used the SOTU the convey important information to Congress and that those addresses contain important information useful for analyzing how, in what way, and why Presidents present their agendas (2006).
} 
shown in the Federalist Papers. A sense of fear and envy is reflected in the treatment of indigenous peoples in the Federalist Papers, where Indians are alternately described as either hostile threats (see Federalist 3, 7, 24, and 25), or potential trade partners, peoples from whom the U.S. could benefit (see Federalist 24, 40, and 42). The Constitution itself acknowledges American Indians as a separate category of persons, leading many government officials to treat Indians as rightfully belonging outside of the American political community as a result (Smith 1997, 131). Tasked with ensuring the physical protection of the United States, and general "law enforcement" (Thach 1969, 66), Presidents necessarily paid close attention to the activities of Indian Nations. Article II of the Constitution is vague. It has been described as "muddled" by Forrest McDonald (1994, 2), and "loosely drawn" by Edward Corwin (1957, 3). The exact reach of executive power, especially during crises, is, therefore, unclear (Bessette and Schmitt 2009, 28). How a sitting President ought to treat indigenous peoples is also opaque as a result. The President's unique oath to preserve the Constitution, coupled with the "interplay of powers and duties" listed in Article II (Bessette and Schmitt 2009, 53), admits for a good deal of leeway in Presidential activity to secure the blessings of liberty (Thach 1969). How Presidential power is utilized, however, largely depends on the person in office (Neustadt 1990,11) and the individual's place in political time (Skowronek 2008, 18).

While important foundational ideas formed the basis of the Presidential powers and duties listed in the Constitution, experiences were used to adapt the office of the President to suit the needs of the United States (McDonald 1985, 261; Tulis 1987, 6-9). So it was that, interested in carrying out his Constitutional mandate, George Washington 
pursued his Indian policy motivated by both ideas and practical necessities. Washington famously argued that the indigenous tribes of North America, and the Cherokee in particular, were in desperate need of civilization. The Washington Administration therefore adopted a policy of peace - Indian wars were raging at the time - and civilization in the hope of bettering the condition of native peoples and securing tranquility on the geographical margins of the United States. Washington's ultimate goal for the Indians was "to draw them nearer to the civilized state; and inspire them with correct conceptions of the Power, as well as the justice of the Government."122 Washington based his particular Indian policy on what the institution of the presidency required of him and what the Constitution permitted him to do.

Washington's annual messages to Congress reveal his Indian policies and official attitudes toward indigenous peoples. The example Washington set in these addresses, especially his first, was that a President need not so much make legislative recommendations as direct Congress toward important matters and report on what the executive had done in the previous year (Hoffman and Howard 2006, 20-21). Washington used his speeches generally to convey information and make recommendations based on that information. One of the most frequent pieces of information that Washington gave Congress was how his administration had been dealing with the various Indian tribes in and around the United States. In his first two addresses, Washington restricted his comments on indigenous peoples to reports of ongoing violence. ${ }^{123}$

In his third address, however, Washington's Indian policy was laid out in more detail, where he argued that "a system corrisponding with the mild principles of Religion

\footnotetext{
122 George Washington, "Eighth Annual Message to Congress," December 7, 1796.

123 George Washington, "First Annual Message to Congress," January 8, 1790; George Washington, "Second Annual Message to Congress," December 8, 1790.
} 
and Philanthropy towards an unenlightened race of Men, whose happiness materially depends on the conduct of the United States," would help guide US officials toward peace and friendliness with their neighbors. ${ }^{124}$ Washington's official concern, presented in these speeches, as Chief Executive was to end the ongoing hostilities between the United States and indigenous peoples. His solution was to impart "the blessings of civilization" to the Indian tribes, as may "suit their condition." ${ }^{125}$ If the tribes were civilized in the American fashion, they might be more amenable to trade as good-natured neighbors, attached "firmly to the United States."126

Washington's fourth address was even more pointed. The United States needed to come up with a plan for "promoting civilization among friendly tribes, and for carrying on trade with them, upon a scale equal to their wants." ${ }^{\prime 27}$ Washington's call to promote civilization came from "an earnest desire to procure tranquility to the frontier; to stop the further effusion of blood; to arrest the progress of expense" and to achieve nationwide peace. ${ }^{128}$ Washington advanced several methods of promoting civilization. First, by the spread of regular, and regulated, commerce with native tribes - the "establishment of commerce with the Indians nations," Washington said, was "most likely to conciliate their attachment." ${ }^{129}$ Second, Washington urged "more adequate provision for giving energy to the laws throughout" the frontier, so that lawlessness on both the part of Indians and American citizens could be dealt with as US justice demanded. 130 "To enforce upon

\footnotetext{
${ }^{124}$ George Washington, "Third Annual Message to Congress," October 25, 1791.

125 Ibid.

126 Ibid.

${ }^{127}$ George Washington, “Fourth Annual Message to Congress," November 6, 1792.

128 Ibid.

${ }^{129}$ George Washington, "Fifth Annual Message to Congress," December 3, 1793.

130 Washington, "Fourth Annual Message."
} 
the Indians," Washington said in his seventh annual message, "the observation of justice it is indispensable that there shall be competent means of rendering justice to them."131 Washington's plan, as related through his annual messages to Congress, for the relationship between Indian tribes and the United States was to teach the "unenlightened" Indians how good government, and civilization, ought to work by example. ${ }^{132}$ Through commerce — unbiased, ethical commerce - the United States could show Indians the benefits of a peaceful market economy. ${ }^{133}$ Through the regular, unbiased application of the law, US officials could teach Indians how a codified legal system works and benefits human beings. A bad example of these things, Washington implied, could move the Indian further from the lure of civilization. Without any explicit constitutional guidance on how the President should deal with indigenous peoples, Washington presented what he felt was the most humane policy toward what he saw as belligerent and uneducated peoples. Justice for the Indian then, based on Washington's messages to Congress, entailed helping them achieve a level of civilization comparable to the United States while interacting with them as friendly neighbors.

Washington thus set forth a policy of civilization, with the intent of establishing peaceful relations between Indian tribes and United States settlements. The Indians would benefit because Washington saw civilization as an abstract good. United States' citizens would benefit, presumably, from decreased Indian attacks and more friendly neighbors who could be potential trade partners and military allies. Washington's view was

${ }^{131}$ George Washington, "Seventh Annual Message to Congress," December 8, 1795.

132 Washington, "Third Annual Message."

133 In his fifth message to Congress, Washington spoke on the need for commerce, "but it ought to be conducted without fraud, without extortion, with constant and plentiful supplies, with a ready market for the commodities of the Indians and a stated price for what they give in payment and receive in exchange." Teaching indigenous peoples the benefits of civilization could only work in the absence of immorality in the marketplace. 
paternalistic - the Indian could not advance without the help of the United States. A line in Washington's eighth message to Congress merits further scrutiny: “...and inspire them with correct conceptions of the Power, as well as justice of Government.”134 By stating that the US has the power to inspire correct conceptions of the power and the justice of the government, Washington implied that indigenous peoples held incorrect conceptions of those important ideas. With this line, Washington identified, consciously or not, a tension between American and indigenous political thought. Indians did not understand, perhaps because they were not taught to understand, the justice inherent in the United States' system of government. The President did not, however, elaborate more on that point in his speech.

Of course, much changed in the United States in the two hundred odd years following Washington's exit from the political stage, including Presidential Indian policy. Yet while individual Presidents held unique beliefs, there are discernable trends in how Washington's successors viewed indigenous peoples and approached their sworn duty to preserve the Constitution. These trends are revealed in an analysis of Presidential addresses to Congress. The treatment of indigenous peoples in the SOTU has, in terms of the raw number of mentions, decreased over time as Presidential attention has been focused elsewhere in relation to global events and crises. This decreasing trend, however, in and of itself, is telling. Indian affairs, up until a certain point, were considered matter of pressing national import. Once all indigenous peoples were made citizens of the United States in the 1920s, coupled with the President's increasing involvement in international affairs, indigenous peoples were more rarely talked about in the SOTU. The silence, with notable exceptions, seems to indicate that indigenous peoples were being

${ }^{134}$ Washington, "Eighth Annual Message." 
taken care of by other departments and were no longer seen as something for the President to worry about.

\section{Andrew Jackson and the Tension between American and Cherokee Political Thought}

Did President Andrew Jackson, a man famous for his poor treatment of indigenous peoples, understand there to be a tension between American and Cherokee political thought? In this section, I analyze the text of Jackson's annual messages to Congress to interpret the extent to which ideological differences played a role in shaping his policies toward Native Americans. In his first inaugural address, given on March 4, 1829, Jackson stated that:

It will be my sincere and constant desire to observe toward the Indian tribes within our limits a just and liberal policy, and to give that humane and considerate attention to their rights and their wants which is consistent with the habits of our Government and the feelings of our people.

As this statement suggests, Jackson was concerned with justice for the Indian tribes. But what sort of justice was he after? The answer to Jackson's question — what is justice for the Indian?-is revealed in his beliefs on the dignity of the human person.

Echoing Washington, and virtually all of his predecessors, Jackson believed the Indian to be in dire need of civilization. It has long been the hope, Jackson said, "of gradually reclaiming [the Indian] from a wandering life" and "their savage habits." 135 The "aboriginal race" is due all the "humanity" of the United States' government because of the superiority of American culture. ${ }^{136}$ Jackson made repeated and insistent reference to

\footnotetext{
${ }^{135}$ Andrew Jackson, "First Annual Message to Congress," December 8, 1829.
}

${ }^{136}$ Andrew Jackson, "Eighth Annual Message to Congress," December 5, 1836. 
the Indian "race" as a means of rhetorically distancing them from white civilization. ${ }^{137}$ These indigenous peoples, for Jackson, needed the help and care of a benevolent people, of "the civilized Christian" and "true philanthropy."138 Jackson's stance on the dignity of the Indian person was limiting. Aboriginal peoples, like the Cherokee, only had value if they emulated American culture and followed American laws. This limiting view of the human person clarifies Jackson's removal policy and what he thought of as just action toward the Cherokee.

Jackson wanted the Indian tribes to civilize; yet once the Cherokee "mingled much with the whites and made some progress in the arts of civilized life" by erecting "an independent government within the limits of Georgia and Alabama," Jackson used that progress against them. ${ }^{139}$ Jackson claimed that he wanted the Indian tribes to civilize, but when they did, he rejected the validity of their civilization. "Under these circumstances," Jackson said, "the question presented was whether the general government had a right to sustain those people in their pretentions," meaning that the Cherokee were pretentious for being too good at emulating white civilization and establishing their own constitutional government on land that, while within the claimed boundary of Georgia and Alabama, was originally theirs, protected by treaty. ${ }^{140}$ State officials in Georgia complained to the President, as they had complained to Jefferson in 1802, and Jackson made it clear that he would side with them over the Cherokee, claiming that the US Constitution tied his hands on the matter. ${ }^{141}$

137 Ibid.; Andrew Jackson, "Second Annual Message to Congress," December 6, 1830; Andrew Jackson, "Third Annual Message to Congress," December 6, 1831.

138 Jackson, "Second Annual Message."

139 Jackson, "First Annual Message."

140 lbid.

141 Ibid. 
Besides, Jackson argued, life in the east was actually bad for the Indians. "Their present condition," Jackson contended, "contrasted with what they once were, makes a most powerful appeal to our sympathies;" some of them "have become extinct and others have left but remnants to preserve for a while their once terrible names." ${ }^{142}$ Their fate, if left in the east, would be to "follow to the tomb the last of [their] race and to tread on the graves of extinct nations." ${ }^{143}$ In his first annual message, Jackson pitched removal as a proprietary measure that would safely set the Indians apart from "the limits of any state of territory now formed." ${ }^{144}$ Furthermore, "this emigration should be voluntary," for it would be "as cruel as unjust to compel the aborigines to abandon the graves of their fathers and seek a home in a distant land." 145 If they remained, they would have to submit themselves to the laws of both the individual states and the United States. Jackson gave the Indians the option of either leaving their sacred homelands or staying and losing the ability to form a distinct and independent political community. The option that the Cherokee had chosen, erecting a constitutional government and remaining, was out of the question, even though the Cherokee had settled down, cultivated the earth, built cities, and generally civilized, as Americans had wanted them to, by adopting a constitutional government in the model of the United States. Jackson's veneer of kindness toward the Indian and desire for them to leave only voluntarily disappeared completely once Congress passed the Indian Removal Act of 1830.

\footnotetext{
142 Jackson, "First Annual Message."

143 Jackson, "Second Annual Message."

144 Jackson, "First Annual Message."

145 Ibid.
} 
In his second annual message, Jackson changed his stance by arguing that the "consequences of a speedy removal will be important to" individual states, to the United States, and especially "to the Indians themselves. ${ }^{146}$ This speedy removal:

Will separate the Indians from immediate contact with settlements of whites; free them from the power of the states; enable them to pursue happiness in their own way and under their own rude institutions; will retard the progress of decay, which is lessening their numbers, and perhaps cause them gradually, under the protection of the government and through the influence of good councils, to cast off their savage habits and become an interesting, civilized, and Christian community. ${ }^{147}$

The difficulty was that the Cherokee had already met, or at least were well on their way toward meeting, the stipulations Jackson listed as desirable for the Indians (McLoughlin 1986, 277-301). Many Cherokee leaders had already converted to Christianity by that point; they had also begun a written newspaper and eliminated certain heinous practices like infanticide, witchcraft, and clan revenge (McLoughlin 1986, 350-353). The Cherokee had established a unified constitutional government, replete with separated powers and institutional branches—-what Jackson called "rude institutions" actually resembled the US government quite closely. ${ }^{148}$ The Cherokee were in the process of pursuing their own happiness in a way as close to the American model as they could get without sacrificing their ancestral political traditions to the whims of American politicians. In short, even the Cherokee, who had advanced the most toward the model of white civilization, were not good enough for Jackson, which suggests that spreading civilization had little to do with Jackson's true policies at all. Removal and the spread of American civilization trumped civilizing the Indians.

\footnotetext{
146 Jackson, "Second Annual Message."

147 Jackson, "Second Annual Message."

148 Ibid.
} 
A generous reading of Jackson might argue that he genuinely believed that remaining in the east would destroy the Indians completely, that they might all perish under the crushing weight of settlers rushing west, grabbing all the land they could get. In this view, Jackson's concern for the well-being of the Indians is revealed in his dedication to giving them their own land out west, far beyond the reaches of American settlement. Yet even if this argument is correct, Jackson still spoke disparagingly of the Indians, whom he lumped into a single category, despite the stark differences between many tribes. Even if Jackson saw removal as a means of genuinely caring for indigenous peoples, he dismissed their differences in his proposal to grant "an ample district west of the Mississippi...to the Indian tribes as long as they shall occupy it, each tribe having a distinct control over the portion designated for its use."149 “All good citizens...will unite in attempting to open the eyes of those children of the forest to their true condition," which is on the brink of extinction, Jackson argued. ${ }^{150}$ The Indians then, according to Jackson, were not all able to understand their plight and had to be taken care of as children.

Did Jackson understand there to be a Cherokee political thought and, if so, did he see that political thought in tension with American politics? Jackson's dismissal of the Cherokee Constitution and government seems to suggest that he did not see the existence of a unique Cherokee political thought at all. "Doubtless it would be painful to leave the graves of their fathers," Jackson said, but "is it supposed that the wandering savage has a stronger attachment to his home than the settled, civilized Christian?"151 This statement suggests that Jackson either had no idea of the importance of the land to the Cherokee or

\footnotetext{
149 Jackson, "First Annual Message."

150 Jackson, "Second Annual Message."

151 Jackson, "Second Annual Message."
} 
that he willfully dismissed the notion. In another passage, Jackson stated that "philanthropic aid and Christian instruction" would be better able to reach the Indians in new territory, unhampered by the "internal regulations" of the states. ${ }^{152}$ By this, Jackson implied that the press of Christian civilization upon the Cherokee and other tribes would really be expedited by removal. The Cherokee were in need of a good upbringing, as it were, according to Jackson, who routinely dismissed any achievement on the part of the Indian.

Jackson's arguments presented in his annual messages to Congress were filled with political rhetoric, designed to convince members of Congress that his Indian Removal policy would be beneficial to the Indians. In the texts of these speeches, Jackson revealed his beliefs about the indigenous person — a crude, savage, being, whose only value to American society came when they submitted to it and adopted American customs. These individuals, Jackson suggested, needed to be brought up as children by a benevolent Christian civilization. That bringing up, however, entailed removing the Indian as far away as possible from that Christian civilization, while at the same time providing for their conversion and transformation. Indeed, even when the Cherokee did emulate white Christian civilization, Jackson wanted them removed for other, legal reasons - Jackson appealed to the provision in the Constitution that said "no new state shall be formed or erected within the jurisdiction of any other state." 153 The Removal policy was all-encompassing and unconcerned with the state of the Indians relative to their perceived level of civilization.

\footnotetext{
152 Jackson, "Third Annual Message."

153 Jackson, "First Annual Message." See Article IV, Section 3 of the US Constitution.
} 
Based on a close reading of the texts of his annual messages to Congress, Jackson either did not perceive the existence of a Cherokee political thought or simply did not acknowledge it. Either explanation is viable. Jackson repeatedly disregarded the Cherokee, and other tribes, as savages, whose approaches toward civilization were tenuous at best. It is unclear from these speeches whether Jackson thought them capable at all of attaining the like of US civilization. The racial prejudice thesis is supported by Jackson's arguments - the Indians, no matter their proclivity for white culture, were all equal in their savagery. The material acquisitiveness thesis also finds support in this analysis. Jackson made repeated comments on "the welfare of our rapidly extending settlements" and the prospect of an "extensive republic, studded with cities, towns, and prosperous farms, embellished with all the improvements which art can devise" on the land vacated by the Cherokee and others. ${ }^{154}$ My ideological incongruence thesis, however, does not find support in Jackson's speeches. This may be due to the selection of cases - restricting the study to annual messages to Congress-yet these messages are broad policy statements that should convey the President's legislative agenda (Hoffman and Howard 2006). In the case of Andrew Jackson, I conclude that he did not reveal an understanding of or appreciation for Cherokee political thought or the tension between that thought and American politics.

\section{Supreme Court Decision-Making and Cherokee Citizenship}

The relationship between the Supreme Court and indigenous tribes is complicated, since "the scope of tribal" power "has not remained static" over time (Duthu 2008, 7). Modern legal scholars and political actors are forced to dig through a vast tome

154 Jackson, "Eighth Annual Message"; Jackson, "Second Annual Message." 
of legal history to arrive at the true nature of this relationship (Edwards 2006; Duthu 2008, 8; Fletcher 2011). Responsible for interpreting the law, the Supreme Court has often found itself at odds with the other two branches of government, whose actors are typically motivated by more political concerns (Segal and Spaeth 2002). In this section, I review the conclusions scholars have made about Supreme Court decision-making and relate these to treatment of the Native Americans.

Despite Alexander Hamilton's assurance in Federalist 78 that the judiciary would be the "least dangerous branch" of the American government $(1961,465)$, critics often decry activist justices for imposing their will on the Constitution (Segal and Spaeth 2002). This contention, that the Supreme Court is increasing its power, rests on the idea that, contrary to Hamilton's account, justices are not incentivized to remain objective. Instead, justices are perceived as arbiters of their own ideological preferences (Segal and Spaeth 2002). By further exploring the legal, ideological, and strategic constraints placed on the Court, however, scholarship has revealed evidence of a muted judicial activism (Bartels 2009; Maltzman et al. 2000). Justices often find themselves unable to behave as activists - cases of wanton partisan policy activism, while an important exception, are not the rule on the bench.

Hamilton wrote that "to avoid an arbitrary discretion" on the Court, "they should be bound down by strict rules and precedents which serve to define and point out their duty" in each case set before them $(1961,471)$. Hamilton's words anticipated a legal model of judicial behavior, a view that decisions of the Court are substantially influenced by the facts of the case in light of the plain meaning of statutes and the Constitution, original intent, and legal precedent (Segal and Spaeth 2002, 48). While judges nationwide 
claim to adhere to such a legal model, where justices are constrained by the exogenous force of the law, scholars are skeptical (Canes-Wrone et al. 2014).

In lieu of the traditional legal model, behaviorists adapted an attitudinal model, which posits that judicial outcomes reflect a combination of legal fact and the policy preferences of each justice (Segal and Spaeth 2002, 111). Although Attitudinalists maintain that the law is important, the votes of justices are primarily shaped by preferences exogenous to the strategic context of the Court. Because legal rules governing decision making in cases that come to the Court do not limit discretion, and because the Supreme Court is the court of last resort, Attitudinalists argue that justices may freely implement their personal policy preferences in their decisions (Segal and Spaeth 2002, 110-112). While the legal model suggests that justices are constrained by precedent and other statutes, the attitudinal model contends that those constraints alone are not as impressive as Hamilton and others may have thought.

Both standalone legal and attitudinal models were subsequently challenged by Bartels, who argued that some rules "significantly constrain ideological discretion, whereas others give justices a significant amount of discretion" to act based on preferences $(2009,475)$. Context matters on the Court - the nature of the case before them often either permits certain liberties or restricts the acceptable range of decisions. According to Bartels, whose study encompassed free expression cases, both legal and attitudinal models have explanatory power in certain situations (2000). Legal precedent and personal preferences are therefore both critical exogenous constraints with varying degrees of severity. 
Where Segal, Spaeth, and Bartels have examined the power of exogenous constraints, Maltzman, Spriggs, and Wahlbeck (2000) have argued that the strategic nature of being on the Court itself, along with policy preferences, shapes judicial outcomes. Focusing on the assignment of Court opinions, Maltzman and his colleagues suggested that there are many situations where justices might deliberately vote against their preferences (2000, 7-8). Strategic justices "take into account the effects of their choices on collective results when they vote on outcomes and write or support opinions" (Maltzman et al. 2000, 13). Not only do legal precedent and ideological preferences form exogenous constraints on the Court, justices are also limited in what they may do by institutional norms and procedures.

Faced with a combination of exogenous and endogenous constraints, Supreme Court justices are generally prevented from behaving as wanton policy activists. In addition, as Segal and Spaeth demonstrated, the Supreme Court displays a habitual deference to federal agencies - rarely do they strike down federal laws (2002, 413-414). Research has also amply shown the Supreme Court's support for cases argued by the Solicitor General, whose side has often prevailed in spite of ideological opposition by the justices (Segal and Spaeth 2002, 411). The interplay between the Court and the other branches of government presents yet another exogenous factor influencing judicial outcomes, to which justices must respond strategically.

Supreme Court justices, while not perfectly objective arbiters of the law, are nonetheless restrained from shamelessly imposing their will on the Constitution. At first blush, the attitudinal model would seem to suggest an activist Court, willing to disregard everything for the sake of their preferences (Canes-Wrone et al. 2014). Segal and Spaeth, 
however, contend that this is not the case, writing instead that "the activist persuasion is rarely articulated" by the Supreme Court $(2002,407)$. Although certain Courts may have agendas of their own, like the Warren Court in its campaign against state laws or the Rehnquist Court with its penchant for striking down federal legislation, even these have been restricted by some manner of legal precedent or strategic calculation (Canes-Wrone et al. 2014; Bartels 2009; Maltzman et al. 2000).

In the 1830s, the Marshall Court found itself retrained by years of legal precedence, established via treaties, legislation, and common practice, on how to deal with indigenous peoples. The case Worcester v. Georgia (1832) presented the court with the opportunity to officially decide on the matter of Cherokee sovereignty, an issue that both Congress and the President had wrestled with many times in the preceding three years (Duthu 2008, 8-11). ${ }^{155}$ Marshall gave the opinion of the court, strategically seizing upon the prospect of articulating Cherokee sovereignty over their ancestral homelands. In contrast to the debates in the Senate in 1830 or Andrew Jackson's messages to Congress, presented above, John Marshall, and Justice McLean in his concurring opinion, stated that the law supported the Cherokee in their right to remain as they were in the east. In the next section, I analyze Marshall and McLean's arguments to determine whether they understood there to be a Cherokee political thought in tension with American politics.

\section{Worcester v. Georgia and the Tension between Cherokee and American Political Thought}

In Worcester v. Georgia, the Supreme Court was tasked with deciding whether the state of Georgia had the authority to regulate interactions between Georgia citizens

${ }^{155}$ Worcester v. Georgia, 31 U.S. 515 [1832]. 
and the Cherokee Nation. More specifically, the Court had to decide whether Georgia could extend its jurisdiction over federal treaty-protected lands held by the Cherokee people. Congress had passed the Indian Removal Act in 1830 and President Jackson had been pressing forward on all fronts his removal policy (Purdue 2016, 116-119). The Court faced the question of Cherokee sovereignty just as Indian removal was becoming a practical reality. Chief Justice John Marshall gave the opinion of the court in a 5-1 decision. ${ }^{156}$

In the process of answering whether Georgia's act expanding its jurisdiction over Cherokee territory was repugnant to the Constitution, Chief Justice Marshall commented on the rights of the Cherokee, including whether they possessed sovereignty power over their lands. The Georgia act was entitled:

an act to prevent the exercise of assumed and arbitrary power by all persons under pretext of authority from the Cherokee Indians; and their laws, and to prevent white persons from residing within that part of the chartered limits of Georgia occupied by the Cherokee Indians, and to provide a guard for the gold mines, and to enforce the laws of the State within the aforesaid territory. ${ }^{157}$

Marshall considered this act offensive to previous treaties conducted between the United

States and the Cherokee Nation, the latter having been considered by the United States since time immemorial a sovereign self-governing nation. The Cherokee, as a selfgoverning nation, when it signed treaties with the United States, always did so as an equal party — the United States acknowledged the Cherokees' sovereign ability to sign a

${ }^{156}$ In Worcester, a Christian Missionary, Samuel A. Worcester, was arrested by Georgia officials and sentenced to four years of hard labor for residing without state approval within the limits of the Cherokee Nation. Worcester, a citizen of Vermont, had been living, preaching, and teaching among the Cherokee, sanctioned by the office of the President. The arrest had taken place after the Georgia legislature passed an act asserting jurisdiction over all Cherokee lands in 1830 that stated that Georgia had the authority to arrest any white man for living among the Cherokee without approval from the Georgia governor and/or for failing to take an oath of allegiance to the Georgia state Constitution (Worcester v. Georgia, 31 U.S. 515, 516-517 [1832]).

157 Worcester v. Georgia, 31 U.S. 515, 541 [1832]. 
treaty, otherwise said treaty could have no legitimacy. ${ }^{158}$ Marshall definitively stated that "the only inference to be drawn from [the text of previous treaties] is that the United States considered the Cherokees as a nation." ${ }^{159}$ That the Cherokee acknowledged the United States to be their protector state was a "practical construction" that did not abandon "their national character" or submit them "as subjects to the laws of a master." $" 160$

The historical precedent argument for Cherokee sovereignty and right of unmolested self-government established, Marshall implicitly questioned whether the Cherokee themselves had value as a people. His answer differed drastically from the conclusions drawn by Sen. Forsyth, Sen. Frelinghuysen, and Andrew Jackson. Like the debates in the Senate and the President's speeches, Marshall agreed that that promotion of those "humane designs of civilizing the neighboring Indians" promulgated by Presidents since Washington was sound policy. ${ }^{161}$ Yet the object of civilizing the Indians, "and their conversion to Christianity," was "to be accomplished by conciliatory conduct and good example, not by extermination."162 In this, Marshall agreed with Washington, who sought above all to provide a positive example for indigenous peoples to persuade them of the goodness of American civilization. ${ }^{163}$ The Indian, for Marshall, in his opinion, was someone in need of education, conversion, and civilizing - but these needs, should they be met, were not going to increase their intrinsic value as peoples.

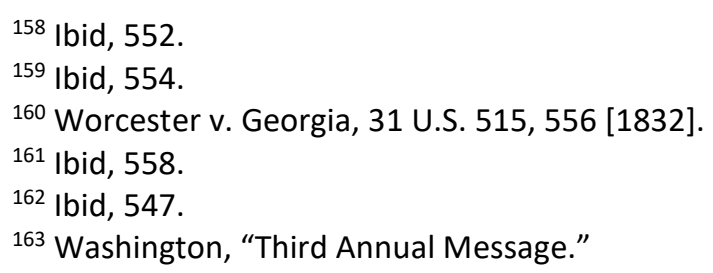


Marshall argued that the Cherokee Nation retained a "preexisting power" to "govern itself," regardless of the form of government they chose to employ. ${ }^{164}$ As long as "self-government and sovereign and independent authority [were] left in the administration of the state," the Cherokee would remain a domestic nation, selfgoverning and untouchable by the state of Georgia or any other state. ${ }^{165}$ For Marshall, the form of the Cherokee government did not make them legitimate. The Chief Justice did not even once mention the fact that the Cherokee had adopted a constitution in his opinion. That fact was immaterial to the argument. The Cherokee were "a distinct people" in possession of "institutions of their own" since well before the arrival of Europeans. ${ }^{166}$ The fact that they were hunters and fishermen did not make them inferior to agriculturists and manufacturers. ${ }^{167}$ This last point is important. Some Senators and Andrew Jackson himself disparaged the Indians for their lack of industry — civilizationand for not employing themselves as the Americans did. Marshall rejected the notion that labor bestows value upon a people, upon the Indians. In this, Marshall hints at the existence of a Cherokee political thought.

Marshall's comments suggest that he recognized a Cherokee political thought, or at least that the Cherokee professed a distinct and ordered belief system all their own. The Cherokee, as original proprietors of the land, and because they had not been conquered outright by European powers - or by the United States — were a domestic nation in control of their own self-government. They were, therefore, beyond the reach of state governments to control. They also, according to Marshall, had their own legitimate

\footnotetext{
${ }^{164}$ Worcester v. Georgia, 31 U.S. 515, 563 [1832].

165 Ibid, 562.

${ }^{166}$ Worcester v. Georgia, 31 U.S. 515, 543 [1832].

167 Ibid, 544.
} 
means of self-governing. The fact that this form of self-government was different from the US model was immaterial. Marshall rhetorically asked whether "the great Creator of all things, conferred these rights over hunters and fishermen, on agriculturists and manufactures?" meaning that Americans, because of their civilization, had no justification for dismissing the value of Cherokee government, no matter its form. ${ }^{168}$ Marshall therefore presented a staunch argument for the Cherokee right to sustain themselves on their lands as an independent government.

Justice McLean, in his concurring opinion, presented a more qualified notion of Cherokee sovereignty. "At no time has the sovereignty of the country," according to McLean, "been recognized as existing in the Indians, but they have been always admitted to possess many of the attributes of sovereignty. All the rights which belong to selfgovernment have been recognized as vested in them." ${ }^{169}$ In other words, the United States has often recognized the Cherokee as possessing the right of self-government, but the US retains the right to "ultimate domain," superior to the Cherokee "right of possession" of the land. ${ }^{170}$ Treaty making, however, for McLean, did not depend upon an equal allocation of sovereign authority. The Cherokee were not a foreign state, but a domestic dependent nation; "they, in some sense, form a State."171 McLean's notion of Cherokee sovereignty was based on his, distinct from Marshall's, view of the humanity of the Cherokee.

McLean pointed asked "is no distinction to be made between a civilized and a savage people? Are our Indians to be placed upon a footing equal with the nations of

\footnotetext{
168 Ibid, 544.

169 Worcester v. Georgia, 31 U.S. 515, 581 [1832].

$170 \mathrm{Ibid}, 581$.

${ }^{171} \mathrm{Ibid}, 582$.
} 
Europe, with whom we have made treaties?"172 In terms of treaty-making ability, McLean agreed with Marshall that, by a long process of treaty-making, the United States had acknowledged the right of the Cherokee to make legitimate treaties as a governing body. "The principles of justice," McLean wrote, "are the same. They rest upon a base which will remain beyond the endurance of time." ${ }^{173}$ It is unclear whether McLean intended for the phrase "principles of justice" to refer to human dignity or simply the honoring of contractual agreements. In either event, the Cherokee had the right to make treaties and were therefore a legitimate governing body. The form of Cherokee government, however, mattered to McLean.

McLean placed much energy into citing Thomas Jefferson, who had encouraged the Cherokee repeatedly to "adopt a regular form of government," a position McLean agreed with. ${ }^{174}$ Should the Cherokee graduate to a more complex, legalized form a government, according to McLean's interpretation of Jefferson, they would be more acceptable to white civilization. On a practical level, this transition to a new form of government would help ease trade and intergovernmental relations. This "humane policy of the government towards these children of the wilderness must afford pleasure to every benevolent feeling." ${ }^{" 175}$ Yet the Cherokee had created a new constitutional government, a fact McLean pointed out. The Cherokee had always exercised independent power in the state of Georgia, which was not a new phenomenon in the 1830s. Moreover, "the exercise of this independent power surely does not become more objectionable as it assumes the

\footnotetext{
172 Ibid, 583.

${ }^{173}$ Worcester v. Georgia, 31 U.S. 515, 583 [1832].

174 Ibid, 589.

175 Ibid, 589.
} 
basis of justice and the forms of civilization." ${ }^{176}$ Essentially, since the Cherokee had begun to transition into the model of white civilization, they should be even more wellaccepted by US citizens, who had ostensibly desired their civilization in the first place.

Overall, McLean was much less interested, in his concurring opinion, in identifying a Cherokee political thought. He sought rather to qualify what Marshall had written about Cherokee sovereignty. McLean's statements were also slightly more paternalistic than Marshall's, who did not emphasize the "erratic life" of the Cherokee in his majority opinion, or their need for correction. ${ }^{177}$ Do these Supreme Court opinions identify a Cherokee political thought? John Marshall's opinion does. McLean's argument is less clear. What do these opinions reveal about the tension between Cherokee and American political thought on the Supreme Court? The Court, tasked with interpreting the law, opted to treat Cherokee political thought in a humanizing way. Marshall, speaking for the majority, wrote that the Cherokee had always been treated by the United States as a sovereign nation, because they were - they relative progress toward civilization, while normatively desirable, did not change the legitimacy of the Cherokee government. The rhetoric employed by both justices was much less pejorative then the words selected by Sen. Forsyth and Andrew Jackson and seems to contradict the racial prejudice thesis argued by some scholars, like David Williams (2005) and Circe Sturm (1998). The Court, unconcerned with popular appeal, ruled on what the text of US treaties implied, that the Cherokee were their own nation, domestic, but still vested with self-governing authority.

\footnotetext{
${ }^{176}$ Ibid, 591. McLean is here referring to the creation of the Cherokee Constitution and new form of government.

177 Worcester v. Georgia, 31 U.S. 515, 589 [1832].
} 


\section{American Institutions and Cherokee Political Thought}

"Historically," according to legal scholar N. Bruce Duthu, "United States—-tribal relations swung like a pendulum," starting with acknowledging Indian tribes as foreign nations, followed by treatments of tribes as domestic bodies subject to "unchecked plenary federal power," and eventually settling into an "ill-defined and precarious government-to-government political relationship" $(2008,165)$. The three institutional case studies I have presented in this chapter reveal a snapshot of this timeline, during the transition from treating tribes as foreign nations to powerless domestic bodies in the 1830s. Congress, the President, and the Supreme Court all discussed, debated, and decided on the relationship between the Cherokee and United States in that decade. The decisions of US political actors transitioned the Cherokee further from being an independent nation toward being a domestic body.

An analysis of the two more vocal senators during the debates over Indian removal in 1830 reveal an acknowledgement of the tensions between American and Cherokee political thought, but not an in-depth discussion of those tensions. This analysis begins to illuminate how Congress treated the differences between American and Cherokee political thought by showing how lawmakers crafted their arguments during a pivotal moment in Congressional Indian policy. Indian removal policy, at least in the $21^{\text {st }}$ Congress, does not appear to be crafted with an adequate understanding of Cherokee political thought on either side of the debate. The senators involved attempted to distinguish the differences between the Cherokee and American governments, but ultimately focused their arguments upon the relative humanity of the Cherokee people and not upon a sincere ideological incongruence between US and tribe. Through the 
analysis of these debates, I find support for the racial prejudice, acquisitiveness, and ideological incongruence theses.

Analyzing Presidential State of the Union addresses is useful for marking the salience of Indian Affairs issues in the national mind, the policies articulated by Presidents, and the ideological arguments underpinning them (Hoffman and Howard 2006). Andrew Jackson did not acknowledge Cherokee political thought in his addresses. The President was concerned with promoting his Indian Removal Act, which he succeeded in doing, using rhetorical flare to simultaneously cast as dire the plight of the Cherokee and their removal as an act of humanity. In analyzing Jackson's speeches, I find support for the racial prejudice and acquisitiveness theses, by not for my ideological incongruence thesis.

A close reading of the court opinions in the case of Worcester v. Georgia reveals how the justices involved articulated Cherokee sovereignty. The Court, more so than the other two institutions, acknowledged that the Cherokee had a unique, and legitimate, form of government that entitled them, as human beings, to exercise self-government over their lands. Here, the political, and prejudicial, rhetoric is subdued. I find support for the ideological incongruence thesis, in that the justices recognized that the distinct brand of Cherokee politics was legitimate and different from the United States.

The strategy of analyzing congressional debates, Presidential speeches, and Supreme Court opinions to ascertain how American institutions deliberated Indian policy can be extended to other pivotal moments in institutional policy shift. The beginning of each broad era of congressional Indian policy may, for example, be viewed through the lens of whether Congress understood the relationship between the United States and 
Cherokee as one of ideological tension or reductive racism. For example, the debates over the 1934 Indian Reorganization Act that ended the policy of allotment and termination may reveal that Congress understood the tension between American and Cherokee political thought differently and therefore attempted to reconstitute their arguments. Those debates might also reveal the opposite. The same can be done for other Presidents during other pivotal moments, such as during the 1960s, with the push for Indian self-determination (Fixico 1986; Duthu 2008).

When individuals, and indigenous groups, are understood by government leaders, they are more likely to feel connected to one another and to the greater political society (Taylor 1994; Tully 1995, 3). If governance is "approached from the perspectives of the struggles of aboriginal peoples, unnoticed aspects of its historical formation and current limitations can be brought to light" (Tully 1995, 4). Noticing how Cherokee political thought was or was not understood in the past, and recognizing that a proper understanding is critical for increasing trust in government and social ease, will pave the wave for more positive policy and decision-making processes in the future. 


\section{Chapter 5: Written in Blood: Tribal Citizenship and the Cherokee Freedmen}

The Cherokee Nation, and other Indian nations, once owned African slaves. These enslaved persons, collectively known as freedmen since their emancipation, have struggled with the Cherokee Nation over the issue of tribal citizenship since 1866. Out of this long battle, both legal and cultural, the Cherokee freedmen have developed nuanced conceptions of citizenship and belonging. Initially limited in their ability to organize politically, these former enslaved peoples advanced a notion of citizenship as having access to the material benefits of membership in a community conferred by the government. As time advanced, the freedmen argued for citizenship based on a mixture of material benefits and their unique identity as Cherokee freedmen. These ideas of citizenship are the result of the freedmen mixing elements of American and Cherokee political thought.

Current work on the Cherokee freedmen may be divided into two categories. First, historical accounts of Cherokee slave-ownership and emancipation place freedmen in the context of the American Civil War and Reconstruction (Bailey 1972; Littlefield 1978; Minges 2003). Second, sociological accounts of freedmen communal identity shed light upon how the freedmen have survived amid pressures from the Cherokee Nation (Sturm 1998; Reece 2002). These pieces, however, pay little attention to how the Cherokee freedmen view citizenship and how that view has developed over time. A third area of scholarship, on multiculturalism and the fusion of diverse peoples into one body

politic, is also relevant here. These works mine the origins of the contemporary focus on cultural recognition (Taylor 1994), explore cultural tensions within liberalism (Glazer 
1975; Kymlicka 1995), and suggest solutions for peaceful mediation between cultures (Tully 1995). While these studies provide guidance for how to approach the topic of liberal multiculturalism, I supplement their theoretical contributions with interpretive analyses focused on citizenship development.

I add to these discussions by performing a critical analysis of the freedmen and applying a new interpretive framework to study how the Cherokee freedmen came to view tribal citizenship. I argue that citizenship for the freedmen-contrasted with the traditional views of American citizenship advanced by Judith Shklar (1991)—developed in two waves. The first wave occurred in the post-Civil War period, from 1866 to 1907. ${ }^{178}$ During this time, the freedmen lacked the political organization to demand much other than the practical benefits that came from citizenship in the Cherokee Nation, like federal payouts for land. Without citizenship status, it was difficult to earn wages or provide for families. The second wave represents an ongoing struggle, begun in the 1970s when the Cherokee National Government was reinfused with administrative authority by Congress. ${ }^{179}$ During this latter period, the desire for citizenship as a means to obtain material benefits remained, but this goal became enmeshed within a desire to reinforce the unique identity of Cherokee freedmen both as members of the larger Cherokee community and as distinct from other United States' citizens.

Understanding the development of citizenship among the Cherokee freedmen is important for two main reasons. First, the Cherokee freedmen are a sizable group of

\footnotetext{
178 These years were chosen to reflect the time between the signing of the peace treaty (known as the Treaty of 1866) between the Cherokee and the United States that officially ended hostilities after the Civil War and 1907, the year that Oklahoma entered the Union-when the Cherokee Nation was dissolved.

179 The Cherokee government was restored in the early 1970s by a series of acts of Congress, permitting the Cherokee Nation to recapture administrative authority over its territory and citizens.
} 
people - one estimate placed the number at around $28,000 .{ }^{180}$ Other Indian nations have faced and still face similar citizenship disputes with the descendants of their formerly enslaved populations as well (Sturm 2014). The desire for citizenship is ultimately a desire for home. Debates over what it means to be a citizen continue to occur in the United States today and have practical ramifications for how individuals live their daily lives. Second, political scientists are concerned with the attachment of citizens to their government (Campbell et al. 1960). The benefits of attachment to the greater community are many, including increased participation and investment in the public good.

Examining how marginalized populations within sub-governments have developed conceptions of citizenship may inform larger efforts to increase unity among diverse groups in the United States. The case of the Cherokee illuminates the larger American contribution to the idea of citizenship and how that idea has been challenged and evolved over time.

This chapter is structured to provide context for and then offer two critical analyses of how the freedmen viewed Cherokee citizenship. In the next section, I provide background information on Cherokee slaveholding, followed by a discussion of the concept of citizenship as it relates to Cherokee political thought. I then break down how the freedmen viewed citizenship in the first period, 1866-1907. That analysis is followed by a critique of the modern freedmen struggle for citizenship, 1970-2019. I separate these analyses to show how freedmen views of citizenship have changed over time. The conclusion places the freedmen's view of citizenship within the broader context of

\footnotetext{
${ }^{180}$ Allison Herrera, “In Limbo: Descendants of Cherokee Freedmen Seek Recognition,” KOSU, Invisible Nations, February 2016. In the interview with the long-time editor of the Cherokee Phoenix, Will Chavez, who has covered the Cherokee freedmen saga for over ten years, Chavez stated that there are approximately 28,000 freedmen living in the Cherokee Nation.
} 
citizenship in America to illustrate how the freedmen have mixed American and Cherokee political thought to service their quest for a place to call home.

\section{Cherokee Slaveholding}

Current work on the Cherokee freedmen, the largest of all former slave populations in Indian Territory, may be split into two main categories. The first grouping is concerned with historical nuance and placing these peoples in the context of American colonialism or Reconstruction (Bailey 1972; Halliburton 1977; Littlefield 1978; Minges 2003; Mandell 2010). The second group is concerned with the survival of the freedmen as a unique community and how these people have formed a cohesive identity from the ostracization placed upon them by the Cherokee (Sturm 1998; Reece 2002; Saunt 2004; Krauthamer 2013).

Slavery existed in parts of North America well before the arrival of European settlers (Halliburton 1977, 4-6). Although most slaves were taken as prisoners of war, there was a "regular commercial traffic in some areas" as well (Halliburton 1977, 5). From the time of first contact with Europeans, the Cherokee actively practiced forced adoption among their captives, forcing them into a kind of indentured servitude (Lauber 1913, 49, 136, 170). Slavery as an institution, in the model of Europe, did not exist before the establishment of white settlements in North America (Mooney 1900, 15-25).

The Cherokee gave institutionalized slavery a home because of the benefits they received from stealing or returning runaway slaves. According to R. Halliburton, French and English colonists hastened to use the Cherokee to sell them stolen slaves from the plantations or villages of the other $(1977,6)$. Colloquially known as slave catchers in 
some areas, the legacy of Cherokee slaveholding was passed down through a combination of cultural pressure and assimilation, as well as family heritage (Corkran 1962). The practice was reinforced by European settlers intermingling with the Cherokee by learning their language, culture, and by marriage (Halliburton 1977).

From the beginning, the relationship between the Cherokee and slaveholding was defined by foreignness. On the one hand, the growing white population, when they did not benefit from dealing with them, feared and felt threatened by the Cherokee (Limerick 1987; Minges 2003). On the other hand, many tribes, including the Cherokee, felt a particular antipathy toward blacks (Halliburton 1977; Madison 2015). For whites, who harbored racial animosity toward blacks and Indians alike, Indian slaveholding represented a potential alliance between enemies of the white race (Littlefield 1978). For the Cherokee, who did not possess a concept of race as such, foreignness determined their perception of outsiders, causing them in many instances to view blacks and whites as inferior (Perdue 1979; Minges 2003; Saunt 2004).

By the 1850 s, the Cherokee had coalesced into a cohesive government, after removal from their original lands by government officials in the Jackson and Van Buren Administrations (Littlefield 1978; Tocqueville 2000). Since the 1840s, the Cherokee had existed under a constitution that required all officials to be blood Cherokee - the focus on blood politics revolved partially around the payments made to the Nation by the US government in exchange for removal. Tensions slowly mounted among the Cherokee between the growing number of "mixed blood" people and the shrinking "full blood" population (Littlefield 1978, 7-10). 
According to Daniel Littlefield, being a full blood Cherokee meant something more than simply racial pride — it meant standing up for traditional Cherokee values and resisting the impulses of white civilization (1978). Full blooded Cherokee, in opposition to white culture, for the most part tended not to own slaves. The slave-owners among the Cherokee, collectively owning more slaves than any other Indian nation, tended to be those with mixed ancestry, whose families had become invested in the practice (Halliburton 1977).

Alexis de Tocqueville observed this phenomenon during his travels in America as well. Tocqueville noted that, while "Europeans [had] not been able to modify the character" of the Cherokee and other tribes by force, tensions had arisen among them due to the mixing of cultures by marriage and social intermingling $(2000,1.2 .10,305)$. With a nomadic society governed by, as Tocqueville put it, "opinions and mores" alone, the Cherokee were so overwhelmed by contact with European civilization that assimilation to the European model of settlement and commerce was inevitable $(2000,1.2 .10,305)$. The Cherokee were thus embroiled in internal sectional conflicts just as the United States was headed toward Civil War.

Patrick Minges argues that prominent social divisions emerged during the $1860 \mathrm{~s}$ (2003). Principal Chief John Ross was caught up between the pro-Union Keetoowah Society, largely comprised of full blood Cherokee, and the pro-Confederacy mixedblooded Knights of the Golden Circle (Littlefield 1978; Minges 2003). These organizations represented the culmination of social divisions that had been present since the Cherokee began mixing their culture with that of white civilization. The issue of slavery affected the Cherokee as it had the United States, albeit in a different manner. 
The debate over slavery among the Cherokee differed from that occurring in the US in that the Cherokee never seriously grappled with the moral ramifications of slaveholding—no serious “abolition societies were ever established” (Halliburton 1977, 11). The division among the Cherokee over slaveholding existed in the sense that traditional values were being expunged by the acceptance and reliance on the trappings of white civilization (Littlefield 1978; Perdue 1979). Cultural survival generally took precedence over debating the morality of human bondage.

In a series of moves made by the Confederacy, the Cherokee, along with the other major Indian tribes residing in what would become Oklahoma, joined the southern cause (Bailey 1972). By the end of the war, however, the Cherokee had switched sides. Due to their geographic positioning, Cherokee lands received harsh treatment during the war, with Union and Confederate soldiers alternately marching through, commandeering the Nation's resources (Gaines 1998). The situation was so bad when the fighting began that many Cherokee families scattered, some heading north to Kansas and others south to Texas depending on their allegiance. Many of these families took their slaves with them. Other slaves ran away to escape behind Union lines (Littlefield 1978).

Many Cherokee leaders had always remained loyal to the Union, despite pressure from the people to join the south. Chief John Ross, who supported the Union and absconded to Philadelphia during the war, declared all Cherokee enslaved peoples free in the model of Lincoln in 1863 - though Ross too had no real power to enforce it. Voluntary emancipation notwithstanding, by the time an official peace treaty was signed in 1866, the United States treated the Cherokee as having acted in violation of all previous treaties by joining the Confederacy (Abel 1925). 
While the Treaty of 1866 essentially revoked and restored many previous provisions of older treaties, one critical change was made to the definition of citizenship. The new treaty defined citizenship as belonging to all native-born Cherokee, all Indians and whites legally adopted by members of the tribe, all freedmen liberated by acts of their masters, and all free blacks residing therein (Littlefield 1978, 28). The treaty, including the new legal definition of Cherokee citizenship, affected all those who could be declared residents of Cherokee Territory within six months of the singing. The Treaty of 1866 formed the basis for many of the ensuing legal battles between the Cherokee and the freedmen.

\section{From Slavery to Life as Freedmen}

The second main collection of work on the Cherokee freedmen is focused on their survival and cohesion as a group amid legal and social pressures placed upon them by the Cherokee and United States (Sturm 1998; Reece 2002; Saunt 2004; Edwards 2006). Supplemented by historical pieces, work on the Cherokee freedmen describes their struggles during and after Reconstruction to obtain both citizenship and a sense of belonging within the greater tribal community. I use these narratives to establish a theory of citizenship development.

The years following the Treaty of 1866 were especially difficult for the freedmen and their families. While the question of citizenship arose almost immediately for the Cherokee Nation as a whole, the formerly enslaved peoples struggled to piece together lives for themselves. The struggles of the freedmen were exacerbated by the ongoing legal and cultural battles between the Cherokee Nation and the United States. In many 
ways, especially in the distribution of resources, the freedmen were left in limbo as the Cherokee sought to assert sovereignty against the encroachments of the United States. The redefinition of citizenship imposed upon them by the US angered many among the Cherokee who felt that they alone, as a sovereign nation, should be able to decide who counted as Cherokee (Halliburton 1977).

The pressure placed on the Cherokee by the United States to include the freedmen as citizens reflected greater efforts to make uniform liberal citizenship laws within American borders. At the end of the Civil War, the Union was galvanized in its crusade to prove that the United States was not a "political community formed of separate sovereign[s]" (Kettner 1978, 334). This push for uniformity inevitably extended to Indian Territory and coincided with legislative efforts to improve the conditions of former enslaved peoples across the continent.

In the latter part of the $19^{\text {th }}$ Century, Congress kept a firm hand on the Cherokee, restricting their sovereignty in several ways - by imposing the new definition of citizenship on them, by coercing the Cherokee to give up lands to railroad companies, and by ignoring reports of squatters and bandits that routinely plagued the Nation (Littlefield 1978; Limerick 1987). Given the ever-increasing number of legal restrictions placed upon them, and conscious of their inability to fully stave off the impulses and practices of white civilization, the Cherokee stood their ground on citizenship (Bailey 1972; Sturm 1998).

The freedmen were often trapped between US policies imposed to help raise their quality of life, such as schooling and job opportunities, and Cherokee resistance to extending voting rights and federal payments to them. Fearing the United States' attempts 
to dictate who would be considered Cherokee, the National Council actively contended for the right to self-determine Cherokee citizenship, citing justifications in treaties and other laws. The Cherokee elected to strictly interpret the provision of the Treaty of 1866 that granted Cherokee citizenship to those who could be counted as residents of the Nation within six months of the signing. Many freedmen, however, were unaware that they had been freed by the Cherokee and the United States. Most did not know that they needed to return to the Cherokee Nation within six months of the signing of the Treaty of 1866 to be counted as Cherokee citizens.

In the final decades of the $19^{\text {th }}$ Century, the political situation in the Cherokee Nation was volatile. Public sentiment among the Cherokee was set against the United States inferring with not only citizenship, but also land - the freedmen in both cases became a dangerous political topic that Cherokee politicians often refused to address (Wardell 1938, 229-231). Once they had organized themselves, often with help from US government officials and other outside actors, freedmen communities discovered that struggling against the Cherokee National Council to improve their quality of life was often fruitless (Bailey 1972,181). The Union Agency told freedmen and those who had trouble dealing with the Cherokee Council to come to the US agency instead, further undermining tribal authority (Bailey 1972).

The real diminishment of Cherokee sovereignty, however, began in the late 1880s. When the time came to receive payment for Cherokee lands sold to the US government, the Cherokee quickly passed an act in 1883 stipulating that the monies, roughly $\$ 300,000$, could only be distributed among blood Cherokee (Bailey 1972). Most of the freedmen and their families were excluded from this decision. Hoping for some 
share in the payout, many freedmen appealed to the Office of Indian Affairs directly, as they had been instructed to in the past. Indian Affairs, having never taken Cherokee authority seriously, thus began larger efforts to dissolve the Cherokee Nation (Sturm 1998, 235).

After numerous attempts by the freedmen to gain access to Cherokee citizenship and benefits, Congress passed major legislation on the subject, culminating in the 1887 Dawes and the 1898 Curtis Acts. The Dawes Act started the process of converting communally held lands within Cherokee Territory into individually owned lots, hoping to simultaneously civilize the Cherokee and make room for white settlement (Sturm 1998). The Dawes Commission, established by the Act, was sent to compile a roster of all residents living in Indian Territory. The Cherokee opposed these measures and resisted their implementation for years (Littlefield 1978, 238).

The Dawes Act receives much attention for its shortcomings (Littlefield 1978; Sturm 1998; Minges 2003). The Dawes Rolls broke down the residents of Cherokee Territory into three categories-Indians, whites, and freedmen. While the Dawes Commission ostensibly categorized people by blood quantum — determining ancestry based on how much racial blood one possessed - the rolls were often inaccurate, as those in charge of counting placed people into categories mostly based on the color of their skin alone (Edwards 2006, 128). Many freedmen who had been citizens before therefore lost citizen status as a result of these clerical errors (Sturm 1998). According to the final rolls, which closed in 1902, there were 4,924 freedmen residing as citizens in Cherokee Territory (Littlefield 1978, 238). Five years later, in 1907, the Cherokee Nation was dissolved when Oklahoma was admitted to the Union. 


\section{A Theory of Citizenship for the Cherokee Freedmen}

Scholarship that critiques Cherokee efforts to exclude freedmen from citizenship at different points in time often approaches the subject from some version of the American political tradition (Sturm 1998; Saunt 2004; Edwards 2006). This tradition, in its general form, reflects the desire for productive and industrious members of the community to have access to the privileges of citizenship-while promoting liberty, equality, and justice (Kettner 1978, 287-288; Shklar 1991; Kymlicka 1995). In this light, the actions of the Cherokee, in their treatment of the freedmen, seem unclear, unreasonable, and even hostile.

The situation is only made clear when we reflect that the multiple traditions of United States citizenship were superimposed upon a society grounded in an ancestral tradition. ${ }^{181}$ Even considering Rogers Smith's (1997) multiple traditions thesis-that American citizenship laws have been borne out of liberal, republican, and ascriptive (prejudicial) traditions maximized for political expedience - the Cherokee response over time to the situation remains obscure. We may better understand how the freedmen came to view citizenship by parsing through the distinct views of citizenship harbored by the Cherokee contrasted with the model of liberal citizenship in the United States.

${ }^{181}$ Scholars have argued that the Western political tradition has often floated atop the notion that political societies are primarily mono-ethnic, deriving from a single language and ancestry (Kymlicka 1995, 1-4). Will Kymlicka has argued that Western thought "has been surprisingly silent on [the] issues" of multiculturalism and ethnic belonging within a liberal society $(1995,2)$.

As discussed in previous chapters, the ancestral political tradition-Cherokee political thought is based on an ancestral political tradition-differs from the American liberal tradition in the emphasis placed upon different types of rule. Aristotle's discussion of the family, the village, and the city is instructive here and provides guidance for understanding the Cherokee penchant for thriving while living in decentralized towns, based on kinship and clan affiliation (1984, 1252b, 15-22). 
Since before first contact with Europeans, the Cherokee believed in the sacred power of relationships between nature and the community. Patterns of living believed to harmonize earth and tribe called the "Old Ways" were at the heart of this ancient Cherokee identity (Awiakta 1993; Minges 2003). Citizenship, if the word may be used, for the Cherokee long indicated a tribal belonging and only referred to a legal condition once the US government intervened and doled out payments for land, removal, or other services (Awiakta 1993; Smithers 2015). To better negotiate with the United States, the Cherokee established a constitutional government in the 1820s that attempted to define legal tribal citizenship (Ross 1985a). ${ }^{182}$

The Cherokee constituted themselves as a sovereign nation in 1827 (Tully 1995, 117). Citizenship in the 1827 Constitution was restricted to individuals inheriting the Cherokee bloodline. ${ }^{183}$ Subsequent Cherokee constitutions maintained that spirit of cultural exclusivity, albeit with varying provisions (Reece 2002; Sturm 2014). This Cherokee view of citizenship stems from an ancestral tradition. This tradition, founded upon a particular ancient set of "opinions and mores" (Tocqueville 2000, 1.2.10, 305), united the Cherokee in the idea of the public good being best obtained by adherence to unique cultural traditions. In this sense, the constitutional Cherokee government more closely resembles a form of ethnic republicanism than American liberalism.

Cherokee citizenship has developed from a long tradition of cultural belief predicated on maintaining the "harmony and balance" that exists between all living things (Mankiller and Wallis 1993, ix). Historically, ancestral citizenship—or tribal membership — was grounded in one's position within one's town and clan (Smithers

${ }^{182}$ Editor, "Constitution of the Cherokee Nation," Cherokee Phoenix, 1 no. 1, February 1828.

183 Ibid. 
2015). Those lacking clan-affiliation "stood outside the Cherokee system of reciprocity and mutual responsibility" (Smithers 2015, 6). A Cherokee citizen had a specific gendered role in a tightly-knit community — a concept distant from the vision of liberal citizenship advanced by the United States. While the Cherokee have in many ways liberalized in the $21^{\text {st }}$ Century, their cultural identity and traditions remain an integral part of both public and private life (Mankiller and Wallis 1993; Conley 2005).

By contrast, the idea of liberal citizenship — marked by principles such as "the primacy of the individual, the neutrality of the contractual state, and the priority and universality of individual rights" (Collins 2006, 6) — was not only oriented toward a different type of lifestyle than Cherokee citizenship but was also imperfectly implemented (Smith 1997). The Cherokee and other Indian tribes were often explicitly excluded from participating in American citizenship (Kettner 1978). Additionally, many in the United States neither believed that the indigenous peoples of their continent could actually be nor wanted them to be citizens (Kettner 1978; Smith 1997). Indigenous peoples actively rejected the mores imposed upon them by white civilization as a result (Tocqueville 2000, 1.2.10). US citizenship not being available or interesting, many in the Cherokee Nation viewed their own tribal citizenship as supreme and guarded it at all costs.

The Cherokee Nation was thus torn between foreign standards of liberal citizenship and the image of Cherokee ancestral belonging. While the Cherokee adopted the US model of legal citizenship in their own tribal government, legal tribal citizenship retained many elements of the ancestral tradition that it was founded upon. It is not surprising then that many in the Cherokee Nation were committed to asserting Cherokee 
authority over the definition of their own legal citizenship. In the period between 1866 and 1907, that meant seeking to maintain the benefits the Nation received from the US while excluding those who were not considered real Cherokee.

The Cherokee gradually fashioned their citizenship laws in the model of the United States, in form if not in content. Although they lacked the same ostensible commitment to the liberal tradition, the Cherokee demonstrated a mixture of liberal and prejudicial policies, supported by the political expedience of relying on their own ancestral tradition. Civic myths, a term used by Smith to denote revered events, figures, or beliefs from a peoples' past, are used by politicians in America and elsewhere to rally voters to a particular cause or party (1997). Likewise, Cherokee politicians would often use principles from their ancestral tradition to politically motivate their constituents (Wardell 1938; Smithers 2015). Political support for ancestral traditions often left the freedmen on the outside looking in (Edwards 2006).

The freedmen were again in many ways caught between a clash of ideas over which they had no control and little direct influence. The United States wanted the Cherokee to adopt the model of liberal citizenship and incorporate the freedmen equally, based on the liberal principles of individual autonomy and universal rights. The Cherokee wanted to preserve the primacy of their ancestral tradition — a form of ethnic republicanism that honored clan, community, and a role-defined way of life-against the encroachments of white civilization. What did this mean for the citizenship of the freedmen? It meant the development of a citizenship idea influenced by Cherokee ancestral culture - yet at the same time, the freedmen were inspired by the American model of equal rights to pursue that tribal citizenship. 
Judith Shklar argued that liberal citizenship in America has primarily had four different meanings for the people living there (1991). These concepts are citizenship as standing, citizenship as nationality, citizenship as active participation, and finally, citizenship as republican statesmanship. I argue that the Cherokee freedmen first viewed citizenship as practical, a loose approximation of Shklar's citizenship as nationality. Once established, the Cherokee freedmen developed a unique view of citizenship as both practical, standing, and ancestral belonging.

According to Shklar, citizenship as standing symbolizes one's place in the social stratum (1991, 2-3). The ongoing struggle for "citizenship in America has...been overwhelmingly a demand for inclusion" in the polity and an "effort to break down barriers to recognition" (Shklar 1991, 3). In short, recognition and acceptance are goals that emerge out of a desire to belong (Taylor 1994, 25-26). Citizenship as nationality, on the other hand, is a more purely legal condition - a formal recognition that a person is a member of a state and is entitled to all the privileges and material benefits of citizenship (Shklar 1991, 4). In America, as Smith points out, this has been characterized in many instances by bigotry, xenophobia, and racism (1997). Yet citizenship as nationality may provide material benefits some are willing to overlook racial overtones to obtain.

Shklar's work reflected a long history of American political thought on the nature of citizenship and how it ought to be viewed. James Kettner described how, in the early days of the American republic, Americans harbored a sense of citizenship based on individual consent that entitled members to fundamental privileges and immunities as articulated in the law $(1978,287)$. These beliefs emerged out of what Smith called the liberal and republican traditions (1997). Adding a prejudicial element to the mix, both 
Smith (1997) and Shklar (1991) understood that US citizenship has often represented exclusion and a simultaneous dedication to equality, liberty, and happiness.

Shklar's notion of citizenship as active participation implies that being a true citizen means ruling and being ruled in turn, a concept taken from Aristotle $(1984,1275 \mathrm{a}$, 20-25, 1277a, 25-30). While an interesting theoretical postulation, there is little evidence that the Cherokee or freedmen debated citizenship as active participation in this sense. A hierarchical concept of citizenship, in which everyone has a specific communal role, also derived from Aristotle, might be closer to how the Cherokee acknowledged citizenship (1984, 1276a, 35-40, 1276b, 1-5, 1277a). Likewise, Shklar's citizenship as ideal republican statesmanship would, by her own admission, seem not to apply very frequently to those residing in the states, let alone those in Indian Territory, and may be placed to the side $(1991,11)$.

Focusing first on citizenship as nationality, the freedmen, suddenly marooned without stable communities or access to basic necessities, began first and foremost to seek out ways to survive. Writers from Tocqueville $(2000,1.2 .10)$ to W. E. B. Du Bois (1994) have characterized the sudden freedom of former slaves as overwhelming. According to Tocqueville, when the slave has been taught to submit to everything but reason, he is disoriented when reason becomes his sole master $(2000,1.2 .10,304)$. Du Bois wrote that "the mass of freedmen at the end of the war lacked the intelligence so necessary to modern working men" and were unable in many cases to earn a living for themselves $(1994,59)$. We therefore expect that former enslaved peoples, uneducated and untrained, would not be able to form a cohesive political community necessary to develop a conception of citizenship that fits into Shklar's categories. 


\section{A Critical Analysis of Freedmen Citizenship, 1866-1907}

Upon emancipation, the Cherokee freedmen wanted a place to live to call home. Their biggest concern was food and shelter (Reece 202, 283). Scattered during the Civil War, taken prisoner or by their masters to other states, freedmen had a difficult time surviving, let alone understanding the need to return six months after a treaty they knew nothing about had been signed (Reece 2002). Since black kinship associations had been torn apart by the war, many flocked to the Union Fort Gibson to seek a new life (Reece 2002). These individuals had had no formal education in the Cherokee Nationaccording to Morris Sheppard, a former slave of the Cherokee, it was illegal to teach slaves how to read or write (Minges 2004, 55-62). In such a position of need, the freedmen struggled to form something resembling a political community. Refugees trickled back into Indian Territory months or years after the deadline for citizenship had passed. ${ }^{184}$ Further complicating the issue, former slaves held in the southern states also ran to Cherokee Territory, expecting greater leniency from the Indians (Reece 2002, 287).

Many individual freedmen decided, for different reasons, that the Cherokee Nation would make the best home. Former enslaved woman Eliza Whitmire recounted the confusion that abounded after the war had ended — most had no idea what to do once freed; some just returned to their old masters out of habit or for safety (Minges 2004, 3339). Likewise, Cora Gillam, owned by Cherokee masters during and before the war, described how many former slaves tried farming, often only receiving compensation in the form of food (Minges 2004, 21-24). The scattered, disheveled communities were thus

${ }^{184}$ As stipulated in the Treaty of 1866, between the Cherokee and United States. 
unable to coalesce into cohesive associations for many years after the Treaty of 1866 went into effect. By the time stable freedmen communities were established, like Foreman in what would become Sequoyah County, the Cherokee had already begun to enforce strict interpretations of their treaty with the US (Reece 2002, 284).

The freedmen's decision to return and belong to the Cherokee Nation was not born out of a firm theoretical conception of citizenship, but rather of a need to survive. The requests made by freedmen of both US and Cherokee governments after 1866 often included little more than the means to survive (Reece 2002, 275, 296). In Shklar's terminology (1991), the early freedmen desired inclusion and recognition to meet the needs of everyday life. For example, throughout the 1870 s, freedmen groups continually made pleas to the Office of Indian Affairs to grant them Cherokee citizenship so that they could work and earn a living (Bailey 1972). When the Cherokee passed an act refusing to share government payments with the freedmen in 1883, many reacted by again petitioning the US government so that they could have a share in the bounty (Bailey 1972, 182; Sturm 1998).

In the absence of a solid collective notion of citizenship or cohesive political organization, citizenship for the freedmen reverted to its most basic meaning - the material benefits individuals receive from living in a nation. Shklar's citizenship as nationality is close, but not the same. Shklar suggests that national citizenship is also tied into the immaterial value of holding American citizenship in the eyes of the rest of the world (Shklar 1991, 4). This drive represented a desire for practical citizenship. We observe this behavior, acknowledging the value of citizenship as a means to material goods, among the freedmen especially during the period between 1866 and 1907. 
The reactions of the Cherokee to their former slaves living among them as free peoples were mixed. Moses Lonian, born in 1857, described how freedmen were directed into low-paying and sometimes no-paying jobs, like farming, felling trees, or mining (Minges 2004, 61). Former slaveholders were occasionally kind and continued to live with and take care of the freedmen and their families, as recounted by Phyllis Petite (Minges 2004, 78-83). Perhaps the most interesting and enlightening interview, however, came from Patsy Perryman. In Perryman's interview, she described both the social stigmas faced by the freedmen in the Cherokee Nation after the war and how children were often responsible for dealing with the US government on behalf of their parentschildren, Perryman included, took to the new education system more quickly than their parents (Minges 2004, 74-77). Perryman herself wrote multiple letters to Washington during the land allotment period on behalf of her parents, who could not read or write to secure the monies or land by themselves (Minges 2004, 76).

The freedmen desire for and attempts to obtain Cherokee citizenship are significant in how they ultimately dissolved Cherokee sovereignty. These peoples desperately needed a place to live and found themselves largely unwanted by the Cherokee and surrounding state governments (Littlefield 1978). Many former Cherokee slaves interviewed in the 1930s described the unease and confusion present after the war had ended and their subsequent fight for survival. ${ }^{185}$ Chaney McNair, born in bondage in 1852, stated that the Union soldiers shaped much of the direction of Cherokee society in the late 1860s by either moving, stealing from, or employing former enslaved persons (Minges 2004, 40-44). Chaney Richardson spoke of the same behaviors attributed to the

${ }^{185}$ We find evidence of how the Cherokee freedmen viewed citizenship and life after the Civil War in the Black Indian Slave Narratives (Minges 2004). 
soldiers and lamented the resulting hardships (Minges 2004, 48-53). US government officials saw the plight of the freedmen as a way to force the Cherokee to be integrated further into American society—since the southern states were forced to assimilate their former slaves, the Cherokee would be forced to integrate them as well by altering what citizenship meant for the tribe.

The US government forcing the Cherokee to legally accept the freedmen as their political equals struck at the heart of the tension between American and Cherokee political thought. The situation of the freedmen and their requests to become part of the Cherokee Nation provided an opportunity to bring Cherokee political thought closer to the norms established by American politics. The US directly assailed the Cherokee norm of hereditary citizenship in the Treaty of 1866 . The Cherokee resistance to incorporating the freedmen, and the freedmen's pleas to the US for help, gave US officials an excuse to condemn the Cherokee as insubordinate - this condemnation eventually led to the dissolution of the Cherokee Nation itself.

The freedmen's request to become part of the Cherokee Nation was entirely reasonable and proper, given their situation. It is not surprising that those formerly enslaved peoples returned to the only home they had ever known to seek shelter from the cultural storm raging in the United States. Not yet a cohesive political community, the freedmen did what they could to survive. That neither the United States nor the Cherokee wanted to incorporate them as full citizenship was beyond their control. The freedmen were simply following the dictates of the natural law, which compel human beings to preserve themselves, a preservation best obtained by uniting with a political society (Locke 1988, II.6.5-15; III.16.9-1). The freedmen were willing to, as Locke puts it, 
contract with a political society for the preservation of their lives and property, but were unwelcome (1988, V.38.12-19; VII.77.1-5; IX.123.16-1). This simple view of citizenship as necessary for survival — as a means for practical living — drove the freedmen to pursue the most viable option open to them, Cherokee citizenship.

The freedmen's request of Cherokee citizenship meant, for the Cherokee, a challenge to their national sovereignty and their brand of political thought. Essentially, the sin of slavery resulted in the United States rewriting the legal definition of Cherokee citizenship. Because legal Cherokee citizenship was so closely intertwined with the idea of belonging to the community — what it meant to be Cherokee — the United States, by rewriting Cherokee legal citizenship, also officially began to change what being Cherokee entailed. Intermarriage had, of course, already put strain on the practice of defining Cherokeeness by blood (Sturm 2002). But the imposition of a foreign power, the United States, brought down a heavy legal hammer on top of Cherokee culture, further reshaping the Cherokee in the United States' image. Cherokee and American political thought were brought closer together by the incorporation of the freedmen into Cherokee society as political equals.

\section{A Critical Analysis of Freedmen Citizenship, 1970-2019}

After the Cherokee Nation was dissolved by the US in 1907, the tension between the two groups dwindled, at least legally. The United States, through the efforts of government officials in both Congress and Indian Affairs agencies, had absorbed both Cherokee and freedmen alike in an increased effort to assimilate all indigenous peoples into conformity with American culture. All Cherokee and freedmen were given United 
States citizenship in 1924, seemingly putting an end to the issue in the eyes of the US government. When Congress restored tribal sovereignty in the 1970s, however, the Cherokee again moved quickly to assert authority over who would be considered a Cherokee citizen (Sturm 1998, 251). ${ }^{186}$

The self-stylized Cherokee freedmen, in the modern period, want a home where they feel like they belong. This desire is similar to and yet different from what their ancestors sought. The modern freedmen have been living in the Cherokee Nation for over one hundred years. Much better organized than they were in the $19^{\text {th }}$ Century, when the Cherokee again began denying freedmen access to tribal citizenship, the freedmen were politically equipped to push back (Edwards 2006, 127). The reason for the freedmen's desire for Cherokee citizenship is no longer simply the need to survive. The freedmen also want to thrive as a distinct group who identify as themselves, as Cherokee freedmen — part of the Cherokee community, yet distinct from it.

The desire for Cherokee citizenship is motivated by both the practical benefits that come from being Cherokee citizens and a desire to affirm a unique cultural identity. By denying tribal citizenship to freedmen, the Cherokee are denying access to federally funded programs intended for Cherokee use only, monies, and voting rights (Edwards 2006, 127). In the 1980s, the Cherokee instituted a policy of blood citizenship - an individual could be considered a Cherokee citizen if they could prove relation to someone listed on the Dawes Rolls (Sturm 1998). After 1983, the Cherokee refused to let many

\footnotetext{
${ }^{186}$ Principal Chiefs Act of 1970, Public Law 91-495, 91st Cong., 2d sess. (October 22, 1970). The Act restored to the Cherokee the ability to elect via popular ballot the office of Principal Chief. Widespread popular elections followed, imbued with a renewed sense of the importance of the Cherokee Constitution and judicial system. See Sturm (2014).
} 
freedmen vote in elections (Edwards 2006, 133). The freedmen responded by organizing and filing lawsuits against the Cherokee.

The legal incursions continued over the next 20 years (Sturm 2014). After many tense encounters, the Cherokee people amended their constitution via special election to formally exclude all those who could not prove relation to someone on the Dawes Rolls. ${ }^{187}$ Challenges to that amendment were seemingly put to rest in 2011 by the Cherokee Supreme Court. Chief Justice Matlock argued that "it stands to reason that if the Cherokee had the right to define citizenship" in 1866 and before, then they would retain the sovereign ability to change it again. ${ }^{188}$ Circe Sturm described in detail how racially charged these proceedings grew to be over time (2014). The freedmen were often pushed to the side as the Cherokee sought to assert sovereign authority against the United States.

The freedmen's arguments for why they desire Cherokee citizenship are also couched in a need to be accepted in their unique cultural identity. Marilynn Vann, president of the Descendants of Freedmen Association (DFA), has stated her desire to ensure that freedmen are secure in their citizenship status with access to full citizenship rights going forward. ${ }^{189}$ Vann, in an August 2017 interview, explained why the freedmen desire Cherokee citizenship. ${ }^{190}$ She argued that, since her ancestors walked the Trail of Tears, labored to build Cherokee cities, and helped "make the tribe," the freedmen are an

${ }^{187}$ Cherokee Nation Registrar v. Raymond Nash et al., SC-2011-02 [Supreme Court of the Cherokee Nation, 2011].

188 Ibid, 8.

${ }^{189}$ Will Chavez, “UPDATE: Freedmen Descendants Have Citizenship Restored and May Vote Sept. 24," Cherokee Phoenix, September 28, 2011.

190 Marilynn Vann, "Cherokee Freedmen Overjoyed by Federal Court Ruling Granting Citizenship," interview by Allison Herrera, PRI, August 31, 2017, audio, 4:40, https://www.pri.org/stories/2017-0831/cherokee-freedmen-overjoyed-federal-court-ruling-granting-tribal-citizenship. 
intrinsic part of Cherokee culture. ${ }^{191}$ The freedmen not only reside among the Cherokee, but also belong with the Cherokee as a single tribal family.

Along with the importance of cultural identity and belonging, Vann also indicated that modern descendants of freedmen desire the material benefits that come with Cherokee citizenship — these benefits include access to tribal healthcare, rental assistance, and other programs for the poor. ${ }^{192}$ Other practical benefits to holding Cherokee citizenship today and historically have included access to federally funded programs, tuition waivers, government payouts, and land allotments (Littlefield 1978; Edwards 2006; Smithers 2015). Vann has not been alone in expressing the sentiment that the freedmen belong with the Cherokee either.

During a town hall meeting in 2011, Muscogee Creek citizen Eli Grayson addressed a group of freedmen who had gathered to discuss the Cherokee Supreme Court ruling that validated the Cherokee decision to exclude freedmen from citizenship. ${ }^{193} \mathrm{At}$ that meeting, the Phoenix reported that Grayson encouraged the freedmen to liberate themselves of the argument that "it's about Indian blood," and reminded them that their "ancestors knew who they were in 1866 . They knew they were not America; they knew they were Cherokee." ${ }^{194}$ Willadine Johnson, a descendant of freedmen, has expressed similar sentiments. Disheartened by the back-and-forth legal proceedings and the uncertainty of citizenship for fellow freedmen descendants, Johnson too harkened back to the Treaty of 1866 as the document that established once and for all that freedmen were

\footnotetext{
${ }^{191}$ Ibid.

192 Ibid.

${ }^{193}$ Will Chavez, "Freedmen Vow to Continue Fighting Cherokee Nation for their Rights," Cherokee Phoenix, August 30, 2011.

194 Ibid.
} 
Cherokee citizens and belonged with the Nation. ${ }^{195}$ On the surface, it seems as though, through their desire for political equality, that the freedmen might view citizenship similar to the way that many Americans do. This is, however, not the case, since the freedmen view inclusion into their own ranks much as the Cherokee do.

The freedmen desire for Cherokee citizenship is based on a blending of American and Cherokee political thought. To join the DFA as a full member, individuals must be able to "prove lineage to the 1898-1914 Dawes Freedmen Rolls." 196 The Cherokee have, in the modern era, also used the Dawes Rolls to establish tribal citizenship, albeit excluding the freedmen portion of the Rolls. The DFA does not desire to open up tribal membership to anyone who wants it, but rather seeks to maintain the exclusivity of Cherokee citizenship while asserting that freedmen have always been party to it. The freedmen then bring in elements of political equality and a desire for inclusiveness found in American political thought with an appreciation of the political value of cultural exclusivity found in Cherokee political thought.

This new conception of citizenship is reflected in Table 5.1, which displays a comparison between how the freedmen viewed citizenship during both the first and second time periods. Again, for the freedmen, practical citizenship means the desire for citizenship specifically for the material benefits granted by living in a community. In addition to viewing citizenship as necessary for practical living, in the latter period

\footnotetext{
195 Will Chavez, "Freedmen Descendant says Issue is Still a Struggle," Cherokee Phoenix, September 23, 2011.

196 "Membership and Official Supporter Application," Descendants of Freedmen of the Five Civilized Tribes Association, accessed January 20, 2019, http://websites.godaddy.com/blob/b94b4dc8e0df-448a-a65831349283b956/downloads/Descendants\%20Membership\%20Application\%20revised\%20\%208\%2025\%20 2014\%20\%20revision\%201\%20(1).pdf?cb52130b\&fbclid=IwAR3AgSQP2BQrNbluVAZ5ZHC50igmbct2PAFIfWMhC39 aQeLQCrFYchgRNbY.
} 
between 1970 and 2017 the Cherokee freedmen have also shown a desire to affirm their unique position in Cherokee society and culture - this is represented as citizenship as standing (Saunt 2004; Sturm 2014). Citizenship as standing, according to Shklar, represents the desire for recognition as an important group in society $(1991,3)$. This demand for inclusion — and a dedication to the exclusion of others—-represents the evolved cohesion of the freedmen and their establishment as a stable political and cultural community within the Cherokee Nation.

Table 5.1: Comparing Freedmen's Views of Citizenship in Two Periods

\begin{tabular}{|c|c|c|c|}
\hline $\begin{array}{l}\text { View of } \\
\text { Citizenship }\end{array}$ & Definition & $\begin{array}{l}\text { Freedmen: } \\
\text { 1866-1907 }\end{array}$ & $\begin{array}{l}\text { Freedmen: } \\
\text { 1975-2017 }\end{array}$ \\
\hline Standing & $\begin{array}{l}\text { Recognition, } \\
\text { acceptance }\end{array}$ & & $\mathrm{X}$ \\
\hline Nationalism & $\begin{array}{l}\text { Legal, material, } \\
\text { immaterial benefits }\end{array}$ & & $\mathrm{X}$ \\
\hline Active Participation & $\begin{array}{l}\text { Sense of duty to be } \\
\text { active in the polity }\end{array}$ & & \\
\hline Ideal Statesmanship & $\begin{array}{l}\text { Only interested in } \\
\text { the public good }\end{array}$ & & \\
\hline Ancestral & $\begin{array}{l}\text { Revered, ancient } \\
\text { customs }\end{array}$ & & $\mathrm{X}$ \\
\hline Practical & $\begin{array}{l}\text { Legal condition, } \\
\text { material benefits }\end{array}$ & $\mathrm{X}$ & $\mathrm{X}$ \\
\hline
\end{tabular}

Finally, citizenship as ancestral tradition is a category not recognized by Shklar. This view of citizenship, absent among many other groups in the United States, reflects how the freedmen have been influenced by and have taken part in ancient Cherokee traditions. As Eli Grayson and others have said, many freedmen view themselves as 
Cherokee, regardless of the amount of Cherokee blood in their veins (Saunt 2004). ${ }^{197}$

Being a Cherokee freedmen means belonging to a unique culture nested within a unique

Cherokee culture. A member of the Cherokee Nation, Jason Tarrell, in 1996 wrote to the

Cherokee Observer, attempting to explain what it means to be Cherokee.

According to Tarrell, being Cherokee is "a question of commitment...it's the way you live and the way your family has lived... you can't suddenly become Cherokee. It's not a club."198 Rose Stremlau's work on Cherokee communities reinforces Tarrell's point (2011). Cherokee culture, while it has experienced periods of growth and decline, remains a special unifying force in peoples' lives_-living as and being a Cherokee means something intrinsically different from simply being born on Cherokee soil (Stremlau 2011, 165-170). ${ }^{199}$ As Vann and others have indicated, many freedmen today as an organization see themselves as living Cherokee culture, not simply as living amidst Cherokee culture.

In August 2017, the struggle between the Cherokee and the freedmen reached US District Judge Thomas Hogan. Hogan remarked that while the Cherokee have been maligned and marginalized by the United States over time, they still do not have the authority to deny citizenship to the descendants of the freedmen, who were to be included in both the Treaty of 1866 and in the Dawes Rolls. ${ }^{200}$ As of 2019, Hogan's ruling stands as the final decision on the ability of the Cherokee to define their own citizenship.

197 Will Chavez, "Freedmen Vow to Continue Fighting Cherokee Nation for their Rights," Cherokee Phoenix, August 30, 2011.

198 Jason Tarrell, “Editorial from a Member," Cherokee Observer, 4 no. 4, April 1996.

${ }^{199}$ Research has, however, found a wide variety of sentiments among the freedmen. In interviews conducted in the 1990s, Sturm found a good deal of apathy among freedmen descendants over whether they would be considered full Cherokee-many seemed not to care either way (Sturm 1998, 251-252).

200 The Cherokee Nation v. Raymond Nash et al. and Marilyn Vann et al. and Ryan Zinke, Secretary of the Interior, and the US Department of the Interior, 13-01313 (TFH) [United States District Court for the District of Columbia, 2017]. 
Legally, the United States' imposition of citizenship upon the Cherokee has prevailed, and the descendants of freed peoples now enjoy full legal citizenship within the Cherokee Nation. It remains to be seen whether the Cherokee will challenge this most recent ruling.

\section{Developing Conceptions of Tribal Citizenship}

On May $16^{\text {th }}, 2019$, three candidates for the office of Principal Chief of the Cherokee Nation participated in a televised forum, where prominent members of the community asked them questions in preparation for the June $1^{\text {st }}$ general election. ${ }^{201}$ During the forum, each candidate was asked to state their position on the tribal citizenship status of the Cherokee freedmen, descendants of formerly enslaved peoples. A US District Court decision in 2017 had ruled that the freedmen were in fact citizens of the Cherokee Nation, despite numerous attempts by the Cherokee government to exclude them. ${ }^{202}$ Each candidate offered a different response, suggesting that, at least in public discourse, the US court ruling did not nurture waves of unity among the Cherokee on the subject.

Cherokee National Councilman Dick Lay, a member of the National Council since 2011, answered first, keeping his comments brief and safe from scrutiny. Lay stated that "issue has been decided, in the federal court and ours. It's the law. And I will abide by and enforce the law as chief, just like I'm doing now as [councilman]. That's my

\footnotetext{
${ }^{201}$ Chuck Hoskin Jr., Dick Lay, and David Walkingstick, “Cherokee Nation's Principal Chief Forum," interview by Royal Aills, RSU Public TV, May 16, 2019, video file, at 22:30, https://www.youtube.com/watch?v=y1MaAlo2o6s (accessed May 19, 2019).

202 The Cherokee Nation v. Raymond Nash et al. and Marilyn Vann et al. and Ryan Zinke, Secretary of the Interior, and the US Department of the Interior, 13-01313 (TFH) [United States District Court for the District of Columbia, 2017].
} 
answer." ${ }^{203}$ Lay's terse, short response — and general refusal to critically comment on the topic — stood in stark contrast to those of his opponents.

Councilman David Walkingstick, also elected in 2011, expressed a different opinion. While ultimately saying that he would uphold the law, Walkingstick reminded viewers that "in 2007 ...there was a constitutional referendum that went before the Cherokee people, to be voted on, to have a Cherokee-by-blood tribe...77\% of [the] people voted on that." ${ }^{204}$ Walkingstick called the case of freedmen citizenship a sovereignty issue — can a tribe, like the Cherokee, determine their own citizenship? When the Cherokee Attorney General did not contest the ruling in 2017, Walkingstick claimed that the Cherokee displayed great weakness in not standing up for what was, in his mind, clearly the will of the Cherokee people - that the freedmen, unrelated by blood, should be excluded from tribal citizenship. The Cherokee Nation, according to Walkingstick, should have fought harder for their sovereign right to self-govern.

Cherokee Secretary of State, Chuck Hoskin Jr., distanced himself from both Lay and Walkingstick in his statement. Hoskin Jr. openly embraced the inclusion of the freedmen. The secretary reminded viewers of his vote "not to exclude the freedmen" in the 2007 referendum. ${ }^{205}$ Since that 2017 decision, the Cherokee Nation, Hoskin Jr. reminded his opponents, had complied with the ruling and sought to grant greater protections for freedmen - the general policy under outgoing Chief Bill John Baker had been to embrace and include the freedmen. If the secretary were elected, Hoskin Jr.

\footnotetext{
${ }^{203}$ Hoskin, Lay, and Walkingstick, "Cherokee Nation's Principal Chief Forum."

204 Ibid.

205 Ibid.
} 
promised to do even more to incorporate freedmen communities. Hoskin Jr. was elected on June $1^{\text {st }}, 2019$ as Principal Chief of the Cherokee Nation with $57 \%$ of the vote. ${ }^{206}$

The differences in each of the three candidates' responses reflect the conflicting views of Cherokee citizenship and the status of the freedmen within the Cherokee Nation. Lay's short response, offered without analysis of the law itself, represents those who would rather not publically discuss the freedmen issue. Walkingstick, in his critique, represents those who believe that the Cherokee Nation should remain fundamentally, and physically, Cherokee- his analysis suggests that sovereignty is more valuable than inclusion. Hoskin Jr., finally, represents Cherokee who welcome the idea of including the freedmen to swell their ranks and embrace their shared history. While Hoskin Jr. did win the election, his victory by no means indicates that the Cherokee are unified on the subject of the freedmen. The subject of the freedmen, who are often seen as not quite outsiders and not quite Cherokee, still causes divisions in Cherokee public discourse, even 153 years after the Treaty of 1866 (Sturm 2014). In this chapter, I put forth one explanation as to why.

The framework advanced here suggests two things. First, that former enslaved peoples face educational and practical barriers to sustaining themselves and thus view citizenship primarily as a means to obtain practical benefits. I call this concept practical citizenship. Second, former enslaved peoples — influenced by a non-liberal ancestral tradition-view citizenship not only as practical but also as a mixture of standing and non-liberal ancestral custom. Many descendants of the Cherokee freedmen today see

${ }^{206}$ Staff Reports, "Cherokee Election Commission Certifies Election Results; Chuck Hoskin Jr. is next Principal Chief," Tulsa World, June 3, 2019, https://www.tulsaworld.com/news/state-andregional/cherokee-election-commission-certifies-election-results-chuck-hoskin-jr-is/article 29a1ff09-ef8c5ba3-8c69-f932e1560728.html (accessed June 6, 2019). 
tribal citizenship not through a purely liberal lens but as something unique to them and their Cherokee heritage.

The first point presents a minor challenge to Shklar's (1991) framework: a full typology of why Americans have desired citizenship, both historically and currently, should include reference to those with no political organization who are driven toward citizenship by survival. The Cherokee freedmen are far from the only group that would fall into such a category. Shklar does, of course, highlight the intrinsic need to earn money and vote as critical to those wanting citizenship (1991, 2-3). Reshuffling Shklar's categories would serve to include formerly enslaved people unprepared to create their own theoretical conceptions of citizenship. This reshuffling - and understanding that the desire for practical citizenship is a temporary state, one that would naturally evolve over time-would also inform broader discussions of why individuals seek citizenship and what it means to them within the United States.

The second point is more complicated. The American liberal lexicon does not readily provide clear understandings of non-liberal political traditions (Kymlicka 1995, 176; Tully 1995). The analysis I provide in this study suggests that understanding complex issues of Native American citizenship requires an appreciation for non-liberal conceptions of belonging and being a citizen. Without this appreciation, events such as the Cherokee freedmen saga or the Cherokees' negative response to Sen. Elizabeth Warren's (D-MA) claim of Native American ancestry remain puzzling, obscured by cultural misconceptions. ${ }^{207}$

${ }^{207}$ Chris Cillizza. "Elizabeth Warren Might Have Actually Made Things Worse with Her DNA Gambit," CNN Politics, October 17, 2018, https://www.cnn.com/2018/10/16/politics/elizabeth-warrendonald-trump-pocahontas/index.html (accessed May 20, 2019). 
The Cherokee freedmen have struggled over citizenship for more than 150 years. Focusing on this issue is important for several reasons. First, because of those affected. The Five Civilized Tribes, as they were called in the $19^{\text {th }}$ Century-the Cherokee, Creek, Chickasaw, Choctaw, and Seminole Nations - each engaged in the practice of slavery. Many peoples within those tribes in the $21^{\text {st }}$ Century still struggle over legal citizenship and belonging as well (Sturm 2014). Additionally, there may be others whose citizenship status in the US is uncertain or insecure due to different understandings of what it means to be a citizen.

The case of the Cherokee freedmen is also valuable in that it instructs us on how views of citizenship develop, especially when they are not grounded in the liberal tradition. To better understand belonging in a diverse nation, such as the United States, where different factions may often resemble different nations (Tocqueville 2000, 1.2.2, 166), we need to parse through what citizenship means for different groups or communities. By doing so, we take seriously Charles Taylor's claim that "nonrecognition or misrecognition can inflict harm" by "imprisoning someone in a false, distorted, and reduced mode of being" $(1994,25)$. While the distinction between citizenship as legal condition and citizenship as belonging may often be blurred, how groups view both may shape the ways they participate in politics.

Attachment to the community is a puzzle theorists and politicians have attempted to solve since before Aristotle (Collins 2005). America has undergone a crisis of citizenship in the past 20 years, particularly since the destruction on 9/11. Susan Collins argues that the 2000s brought a renewed awareness of different forms of citizenship —not only of legal citizenship but also of what it means to be a good citizen in the model of 
Aristotle. Collins reminds us that the idea of the good citizen, and the lessons we may take from Aristotle, apply to all societies. Understanding how different societies and people view citizenship is critical to understanding belonging and meaning in our world (Collins 2006, 5, 78).

During the first wave, from 1866-1907, the freedmen, unable to organize, viewed citizenship generally as necessary for providing material benefits. The freedmen desired to earn wages and vote, so they could earn more wages (Shklar 1991, 2-3). Even prior to those desires, however, most were focused on survival (Minges 2004). This simple view of citizenship, practical, was different from the clashes that occurred between the US and the Cherokee over sovereignty and ancestral custom. For the freedmen, government existed to help them meet basic needs - while they often needed to fight to have those needs met, they did so to establish themselves as part of a larger community (Reece 2002; Saunt 2004).

Once established as a political community, however, the idea of citizenship for the Cherokee freedmen developed to include notions of citizenship as a mixture of practical benefit, standing, and ancestral tradition. Along with inclusion and recognition, the modern freedmen implicitly seek the exclusion of those who do not share their ancestral tradition. There is a modern "assumption that culture is an irreducible and constitutive aspect of politics" (Tully 1995, 5). The contemporary freedmen descendants exhibit a much more concrete idea of the unique culture they represent.

The second wave, from 1970-2017, saw the freedmen descendants battling for citizenship in a different way. These peoples had already established themselves among the Cherokee and had been immersed in Cherokee culture for decades. Freedmen 
communities in this latter period have thought of themselves as a unique society within a unique society, reinforcing their conviction to battle for Cherokee citizenship.

Citizenship, therefore, no longer simply means access to material benefits-citizenship reflects a desire to be recognized and accepted by Cherokee society, to obtain legal and material benefits from the government, and to be accepted as an integral part of the ancient Cherokee culture, distinct from the United States. ${ }^{208}$

Of course, the positions of both Cherokee and freedmen presented in this study are generalized to an extent, extrapolated from the opinions of leaders and official policies. Modern Cherokee Chiefs Chad 'Corntassel' Smith and Bill John Baker have either campaigned and argued against including freedmen as Cherokee citizens or distanced themselves from the issue respectively. ${ }^{209}$ Some Cherokee, like David Cornsilk, former editor of the Cherokee Phoenix, have actively favored freedmen citizenship (Sturm 1998, 252). Likewise, freedmen leaders like Marilynn Vann are passionate about their cause. Yet Sturm, who has extensively studied the freedmen, "had little luck in finding a contemporary freedman descendant who thought tribal recognition was worth the trouble" in the turbulent 1990s $(1998,254)$.

While tensions do exist within the ranks of Cherokee, freedmen, and indeed US citizens over what it means to belong to a tribe, the facts remain. The freedmen have struggled legally for recognition for over 150 years. I have argued here that while American citizenship laws may have been born out of liberal, republican, and ascriptive

\footnotetext{
208 Interviews and editorials published by the Cherokee Phoenix exemplify this desire of many freedmen activists to reinforce their image as one uniquely freedmen, Cherokee, and not American. (See Sturm 2014 for additional coverage).

209 Justin Juozapavicious, “Cherokee Nation Misses Election Pact Deadline," Chronicle Times, 142 no. 150, September 28, 2011.
} 
traditions (Smith 1997), the traditions influencing how people view citizenship are much more diverse. Understanding and appreciating different pockets of our 'strange multiplicity' advances intercultural dialogue within the United States (Tully 1995, 30).

There are many sub-governments and subcultures on American soil today whose citizenship status is either contested, uncertain, or in transition. Understanding how these groups view citizenship — what they expect from it and what it entails—may be key to increasing a broader sense of American unity. Further research into how these subcultures in America understand citizenship and meaning is warranted, especially work that illuminates cultures not influenced historically by the liberal tradition. Their stories and views, often not paid attention to in American political thought, help comprise our unique polity and may shed light on our future.

The standard narrative in American politics today permits two viable options when analyzing the case of the Cherokee freedmen. Americans could side with the Cherokee, a people who have been marginalized, stigmatized, harassed, and bloodied by US government officials and citizens for generations. Supporting the Cherokee against the United States would seem a means of correcting past injustices. Americans could also side with the freedmen, a people whose ancestors have been enslaved, who have been marginalized, stigmatized, and forgotten by both Cherokee and United States' citizens. Siding with the freedmen would also seem a means of correcting past injustices. Supporting the Cherokee, however, by allowing them to self-govern, would also support disenfranchising the freedmen. Siding with the freedmen, alternately, by forcing the Cherokee to absorb them into their tribal nation, would mean supporting the dissolution of Cherokee sovereignty. The moral choice between the two is not obvious. The choice 
itself, however, is a political reality that Americans must to contend with, if only to satisfy the principles of justice. 


\section{Chapter 6: Ruling or Being Ruled?}

An inescapable question posed by the study of Cherokee citizenship is whether the Cherokee are ruling themselves or being ruled by the United States. The simple answer, of course, is that both statements are and have long been true. That fact is part of what makes the study of indigenous citizenship so complex and thought-provoking. The political reality today is that the Cherokee government is partially sovereign (Duthu 2008, 164-165). Unlike a truly sovereign nation, in the Lockean sense of the term, the Cherokee do not have the ability to raise an army to defend or expand their borders, they cannot pass any legislation they see fit for the common good (including legislation defining Cherokee citizenship), and they cannot enter into diplomatic compacts with foreign nations without US government approval (Duthu 2008, xxix-xxx, 206-216). ${ }^{210}$ Yet despite these limitations, the Cherokee do enjoy a measure of sovereign authority over their own affairs.

Ideological incongruence, along with racial prejudice and acquisitiveness, has shaped US-Cherokee relations in general and Cherokee citizenship specifically. Reductionist theories which suppose that the relationship between the Cherokee and United States governments are explained solely by racism or greed miss the bigger picture. Tribal governments are grounded in an illiberal tradition that is, in a few critical ways, diametrically opposed to American liberalism. That statement is not an endorsement of either Cherokee or American political thought over the other, but instead a recognition of an incompatible ideological tension.

\footnotetext{
${ }^{210}$ Locke, in The Second Treatise, details the legislative, executive, federative, and judicial powers and how sovereign governments utilize them (1989, IX, X, XI, XII).
} 
I have broken this chapter into two sections to address two issues undiscussed in the body of this dissertation. The first section deals with scholars' attempts to reconcile the differences between liberal and non-liberal regimes, like the United States and indigenous peoples. This section is important because it shows what a review of history has confirmed, that there are no easy solutions to this ideological tension. Yet there are solutions that may encourage positive discourse and just policy solutions. In the second section, I discuss what it means to be a citizen by comparing Cherokee citizenship with the Aristotelian model. I end the dissertation with this discussion to note that there are valuable principles contained within Cherokee political thought, rejected by many US officials over time, which have merit and may provide insight into the nature of citizenship. Ultimately, there is much of value Americans may learn from Cherokee political thought, concepts like the importance of community, family, and consensus. By dismissing Cherokee political thought wholesale, we risk losing the good embedded within.

\section{Solutions to the Tension between Cherokee and American Political Thought}

Some scholars have attempted to find ways to work around the differences between indigenous peoples and liberal regimes (Glazer 1975; Taylor 1994; Kymlicka 1995; Tully 1995). Will Kymlicka has argued that in order to find fair and workable policy solutions, politicians and scholars need to fashion a new theory of minority rights $(1995,1)$. This new theory of minority rights should include, according to Kymlicka, both universal rights applicable to all and group differentiated rights applicable to certain minorities, like indigenous peoples $(1995,6)$. The official sanction of group differentiated 
rights should contribute to a more comprehensive system of justice. There is, however, a catch. Kymlicka also argued that any and all group differentiated rights must be compatible with liberal principles. Kymlicka defends "the right of national minorities to maintain themselves as culturally distinct societies, but only if, and in so far as, they are themselves governed by liberal principles" $(1995,153)$. By this logic, the Cherokee government should only be allowed to self-differentiate if they conform to liberal principles, which, as I have shown, they have not and do not do.

This thesis brings up an old tension within liberalism. "Tolerance itself is a fundamental liberal value," Kymlicka wrote, "Yet promoting individual freedom or personal autonomy seems to entail intolerance toward illiberal groups" $(1995,154)$. As a "national minority," American Indians are in a difficult situation - their illiberal practices must be negotiated out of them in order to conform to Kymlicka's thesis $(1995,167)$. By Kymlicka's standards, the solution to the ideological tension between the Cherokee and United States is to change the Cherokee-something that US government officials have tried to do since they first encountered indigenous peoples. Even still, the concepts of differentiation and political equality are in conflict with one another. If the Cherokee were to become entirely liberalized in the model of the United States, they would have difficulty justifying singling themselves out as a distinct people without some official US government intervention.

James Tully offers a somewhat different solution to whether a "modern constitution" can "recognize and accommodate cultural diversity" $(1995,1)$. In his analysis of what it means to be a multicultural polity, Tully argued that each group within the "strange multiplicity" of modern society yeans for self-rule — to rule themselves 
according to their own customs and ways $(1995,5)$. Expressions of different cultures often come into conflict with one another and demand political resolution. Tully suggested that if the unique cultural mores of citizens were recognized and taken into account in reaching an agreement on a form of constitutional association, the constitutional order, and the world of every day politics it constitutes, would be just with respect to this dimension of politics (Tully 1995, 6). How may a modern constitutional regime address the difficult problem of cultural diversity? Tully argued that the accommodation of cultural diversity, through intercultural dialogue and activity where diverse sovereign citizens of contemporary societies negotiate their forms of association over time in accordance with the conventions of mutual recognition, consent, and cultural continuity is the most just solution (Tully 1995, 30). Justice, for Tully, depends upon the dialogue, not that all parties agree, but that all parties agree on the same foundational principles — mutual recognition, consent, and cultural continuity.

Where Kymlicka suggested that illiberal practices should be negotiated out of illiberal societies, Tully instead argued that a mediated peace is the best way for culturally diverse peoples to coexist. A successful example of this mediated constitutionalism, Tully argued, may be found in the history of "mutual recognition and accommodation" between the British Crown and the Aboriginal peoples of America $(1995,117)$. Tully refers to their arrangement as treaty constitutionalism $(1995,117)$. John Marshall, in his Worcester v. Georgia (1832) opinion, argued that "it is difficult to comprehend the proposition that [the native peoples or the white settlers] could have right original claims of dominion over the inhabitants of the other, or over the lands they occupied" (Tully 1995, 117). Tully's thesis seems to reflect the attempts made by the 
Washington Administration to treat with the Indians as sovereign nations and promote peace as much as possible between friendly neighbors, a policy goal legally reinforced by John Marshall.

Both of these approaches suggest a compromise, where indigenous nations are either negotiated with to conform to liberal practices or left to their own devices in a peaceful mediated settlement, as long as all parties accept the principles of mutual recognition, consent, and cultural continuity. A lasting peace requires understanding and respect between all parties involved. It may be in the United States, as some have argued (Bradley and Seton 2005), that the history of violence between the US and Cherokee is too great to ever truly repair. But simply because a political relationship has been tainted by racial prejudice and acquisitiveness in the past does not mean that relations cannot be mended moving forward. Ideological tensions must be addressed by informed political leaders on both sides who fully understand both the historical significance of the political relationship between the Cherokee and United States and the needs and wants of individual political communities. Part of an amelioration will come from an appreciation of the principles beneficial to society that Cherokee political thought has to offer. These I discuss in the concluding section.

\section{Aristotle, Citizenship, and the Cherokee}

What does it mean to be a citizen? In perhaps the most famous articulation of citizenship, Aristotle defines a citizen "in an unqualified sense" as those who "share in decisions and office" (Pol. 1275a19-20). The activities associated with partaking in decision-making and office-holding include, for Aristotle, voting, serving on a jury, and 
assembling (Pol. 1275a21-26). Whomever is entitled to participate in an office involving deliberation or decision is a citizen (Pol. 1275b15-20). A citizen is thus someone who participates in the office of a citizen. The excellent citizen need not be an excellent human being (Pol. 1276b, 16-25), but they must have "the capacity to rule and be ruled" and "share in prerogatives" (Pol. 1277a25-26, 1278a35-36). This qualification necessarily presupposes exclusivity. Not everyone can be capable of doing these things. Just as in the Ethics, where Aristotle suggested that the activity most conducive to human happiness and excellence, contemplation, may only be accomplished by a select virtuous few, so too is excellent citizenship reserved for a few (NE 1177a13-20, 1103a24-25, 1123b1-15). ${ }^{211}$ That is, certain members of society, according to Aristotle, are naturally excluded from participating in the office of a citizen.

Judith Shklar has written that Aristotle's citizenship was reserved for a "masterclass" of educated people $(1991,29)$. In a republic of equal citizens, like the United States, such exclusivity, though many Americans once held it in high esteem (Kettner 1978), theoretically has no place (Shklar 1991, 64). Citizenship, according to Shklar, is not tied to the public good like Aristotle's “outmoded notion of public virtue" suggested (1991, 67). Americans have instead adopted more of a Lockean idea of citizenship —all human beings have a right to self-improvement, education, and advancement (Shklar 191, 68). It is, as Locke suggested, rational and becoming for all people to be useful in the world (1996, III.202-212). Modernity, Shklar has argued, demands independence on the part of the citizen, not a tether to some form of communal virtue (1991, 63). Voting and earning are the cornerstones of Shklar's view of American citizenship. Voting is “an

\footnotetext{
${ }^{211}$ References to The Nicomachean Ethics are from the 2011 University of Chicago Press edition, translated by Robert C. Bartlett and Susan D. Collins; the Bekker numbers appear in parentheses.
} 
affirmation of belonging" (Shklar 1991, 26). Earning is an affirmation of independence and usefulness. How is this different from Aristotle's view? In the Lockean tradition, citizenship is predicated on an "express promise and compact" and "positive engagement" (Locke 1989, VIII.122). Anyone permitted to make that express compact, and submit themselves and their possessions to the law, is a citizen (Locke 1989, VIII.117-119, 121-122). In this manner, disparate peoples may, hypothetically, become political equals. The idea of citizenship grown out of this tradition that focuses on contractual consent, labor, and equality, is, according to Shklar, the consummation of a diverse peoples' desire for inclusion—citizenship as standing (1991, 14). Citizenship brings acceptance and solidifies one's place in the polity.

In some ways, Shklar's rejection of his arguments is unfair to Aristotle, who was not concerned with the incorporation of diverse peoples so that all might be included. Instead, Aristotle sought to identify the activity of a citizen and who participated in that activity. According to Shklar, a citizen votes and earns, independent of outside (government or social) bondage. For Aristotle, a citizen takes on the responsibility of the public good. This role is much deeper, more specialized, and perhaps more important. Consider that Aristotle, argued that that which is in possession of the most authoritative reason naturally ought to rule (Pol. 1254b1-10). Since individuals have different capacities for reason, it follows that some will be more adept at ruling than others (Pol. 1252a30). Those who are fit to rule are governed by the mind, whereas those fit to be ruled are more generally governed by the body (Pol. 1253a20-25, 1254b20-30). Human beings are naturally arrayed in an ordered hierarchy optimal for political society. ${ }^{212}$ Men

\footnotetext{
212 Reason must always rule in every situation. That a master, one who has a greater capacity for reason, must rule over a slave, one who has very little capacity for reason, seems fairly logical. But how
} 
and women both possess reason and deliberation, but they do so in fundamentally different ways; nature has constructed them so that they might each specialize in their own particular roles that compliment and improve the condition of the other (Pol. 1259a40). All human beings possess the same parts of the soul, "but they are present in different ways" (Pol. 1260a10). The same may be said for the virtues of character; all possess them, but not in the same way. Nature has provided mankind with the capacity to form a city, which is the end of human partnerships (Pol. 1252b29-33). To form that city, human beings need to individually own social characteristics that help to propel the community toward that end.

I highlight this comparison not to judge either Shklar or Aristotle right or wrong, but to illustrate how Shklar's conceptual rejection of Aristotle serves as a proxy for how American society rejected Cherokee political thought. Shklar's view emphasizes the inclusion of diverse peoples into a single, legal polity. Legal citizenship in the United States assuages individual differences by promoting political equality. ${ }^{213}$ In essence, Shklar focuses on human differences as something that need to be eliminated, at least in the public sphere. Aristotle, on the contrary, focused on human differences as a natural phenomenon that are not, and cannot be, altered by the law. For Aristotle, the public and private spheres were the same; human beings have special roles to perform based on their situation in life. For Shklar, and Locke, human beings have the capacity to work their

\footnotetext{
does this argument that the one with the greater capacity for reason should rule apply to the relationship between men and women? Aristotle contends that men, by nature, are inherently better leaders than women and therefore ought to uniquely partake in political rule (Pol. 1259a40). What Aristotle means specifically by this claim is unclear. If we are to understand Aristotle as creating a sort of evolutionary argument about human beings, then it is possible that he means to say that men have historically been hunters and warriors, leading through physical feats of strength and endurance. This remains, however, a point of debate.

${ }^{213}$ At least in theory (Shklar 1991, 15-17).
} 
way into a state of equality with one another. The Cherokee, it should be clear to the reader at this point, viewed society in a much more Aristotelean than Lockean manner. The Cherokee did not see natural differences as something to be overcome, but rather as something to take advantage of when organizing communal activities, like governing (Stremlau 2011, 22; Smithers 2015, 6-8). Shklar rejected Aristotle for being outmoded. So too many in the United States rejected the Cherokee for their perceived archaic form of government.

As with any complete rejection of Aristotle, the United States' wholesale dismissal of Cherokee political thought threw out, along with a few inhuman practiceswitchcraft, clan revenge, and infanticide were some of the worst offenses (McLoughlin 1986, 389)_positive human lessons on the value of community consensus, a spiritual appreciation of nature, and the harmony that can come from an ordered society dedicated to the public good. Susan Collins has argued that Aristotle remains relevant for his understanding of the relationship between being a citizen and living well as a human being $(2006,5)$. Aristotle helps clarify the perspectives of cultures "that do not share American values" as well as the "full significance of 'what is a citizen?' as an enduring human concern" (Collins 2006, 3). Shklar's take on American citizenship implicitly asks, not unjustly, "what can the government do for you?" In her book, American Citizenship: The Quest for Inclusion, Shklar answers that what America can do for you is make you equal (1991). The views of Aristotle, and the Cherokee, instead beg the question "what can you do for your community?" Collins argues that Aristotle remains valuable to a liberal democratic society like the United States because his writing are infused with a search for, and a conclusion about, fundamental truths of human nature $(2006,167)$. 
Liberal thought in the United States, Collins claims, articulated in the writings of John Rawls, has settled on the "radical claim that rational principles espoused by early modern thinkers...are contingent historical facts that may be superseded by different, equally contingent, facts in the future" $(2006,167)$. Collins means that certain strains of American political thought have rejected the existence of fundamental truths, including truths about human nature. If all human beings are, in fact, political by nature, then certain political activities will always be more fulfilling than others.

The Cherokee propped up family life and familial ties as the most important component of a well-ordered society. If the family was good, society was good, and vice versa. They strove to protect their extended family by excluding others from citizenship and creating a society dedicated to preserving their traditional belief systems. Of course, in their exclusion of non-Cherokee, the Cherokee did harm to the freedmen, who were in desperate need of charity and aid once freed. But the fact that the Cherokee were, like citizens of the US, not angels, should not detract from the emphasis they placed on strong familial ties to strengthen the political community. A resurgence of concern for the stability and health of the family within the United States can cultivate a more positive political environment where policies are made that reflect the dignity of all human life. The past is already written; but the future may still be changed. 


\section{Works Cited}

Abel, Annie Heloise. 1925. The American Indian Under Reconstruction. Cleveland: Arthur H. Clark co.

Adair, James. 1930. Adair's History of the American Indians, edited under the Auspices of the National Society of the Colonial Dames of America, in Tennessee, by Samuel Cole Williams. Edited by Samuel Cole Williams. New York: Promontory Press.

Adams, John Quincy. 1842. The Social Compact. Providence: Knowles and Vose.

Alfred, Taiaiake. 1999. Peace, Power, and Righteousness: An Indigenous Manifesto. Oxford: Oxford University Press.

Aquinas, St. Thomas. 1968. On Being and Essence. Translated by Armand Maurer. Toronto: The Pontifical Institute of Mediaeval Studies.

Aristotle. 1984. The Politics. Edited and Translated by Carnes Lord. Chicago: University of Chicago Press.

Aristotle. 2011. The Nicomachean Ethics. Translated by Robert C. Bartlett and Susan D. Collins. Chicago: Chicago University Press.

Arnold, R. Douglas. 1990. The Logic of Congressional Action. Yale University Press.

Awiakta, Marilou. 1993. Selu: Seeking the Corn-Mother's Wisdom. Golden: Fulcrum Publishers.

Bailey, M. Thomas. 1972. Reconstruction in Indian Territory: A Story of Avarice, Discrimination, and Opportunism. Port Washington: Kennikat Press.

Barber, Sotirios A. 2014. Constitutional Failure. Lawrence: University Press of Kansas.

Bartels, Brandon L. 2009. "The Constraining Capacity of Legal Doctrine on the U.S. Supreme Court.” American Political Science Review 103 (3): 474-495.

Bessette, Joseph M. and Gary J. Schmitt. 2009. "The Powers and Duties of the President: Recovering the Logic and Meaning of Article II," in The Constitutional Presidency, Edited by Joseph M. Bessette and Jeffrey K. Tulis. Baltimore: Johns Hopkins University Press, 28-53.

Bradley, John, and Kathryn Seton. 2005. "Self-Determination or 'Deep Colonizing': Land Claims, Colonial Authority and Indigenous Representation," in Unfinished 
Constitutional Business: Rethinking Indigenous Self-Determination, Edited by Barbara A. Hocking. Canberra, Australia: Aboriginal Studies Press.

Brown, Catharine. 2014. Cherokee Sister: The Collected Writings of Catharine Brown, 1818-1823. Edited by Theresa Strouth Gaul. University of Nebraska Press.

Campbell, Angus, Philip E. Converse, Warren E. Miller, and Donald E. Stokes. The American Voter. New York: John Wiley and Sons, Inc.

Canes-Wrone, Brandice, Tom S. Clark, and Jason P. Kelly. 2014. "Judicial Selection and Death Penalty Decisions.” American Political Science Review 108 (1): 23-39.

Castile, George Pierre. 2006. Taking Charge: Native American Self-Determination: Federal Indian Policy, 1975-1993. Tucson: The University of Arizona Press.

Ceaser, James W. Ed. 2006. Nature and History in American Political Development: A Debate. Cambridge: Harvard University Press.

Cherokee Nation. 1852. Laws of the Cherokee Nation. Tahlequah: Cherokee Nation.

Cherokee Nation. 2010. Building One Fire. Edited by Chadwick Corntassel Smith and Rennard Strickland. Norman: University of Oklahoma Press.

Cherokee Nation. 2017. Cherokee National Treasures: In Their Own Words. Edited by Shawna Morton Cain, Pamela Jumper Thurman, and Betty Christine Frogg. Norman: University of Oklahoma Press.

Collins, Susan D. 2006. Aristotle and the Rediscovery of Citizenship. Cambridge: Cambridge University Press.

Conley, Robert J. 2005. The Cherokee Nation: A History. Albuquerque: University of New Mexico Press.

Corkran, David H. 1962. The Cherokee Frontier: Conflict and Survival, 1740-1762. Normal: University of Oklahoma Press.

Corwin, Edward S. 1957. The President: Office and Powers, 1787-1957, 4th rev. ed. New York: New York University Press.

Curry, Steven. 2004. Indigenous Sovereignty and the Democratic Project. Hants, England: Ashgate Publishing, Ltd.

Dahl, Robert A. 1956. A Preface to Democratic Theory. Chicago: University of Chicago Press.

Debo, Angie. 1940. And Still the Waters Run: The Betrayal of the Five Civilized Tribes. Princeton: Princeton University Press. 
Dow, Jay. 2017. Electing the House: The Adoption and Performance of the US SingleMember District Electoral System. Lawrence: University Press of Kansas.

Du Bois, W. E. B. 1994. The Souls of Black Folk. Dover Publications Inc.

Duthu, N. Bruce. 2008. American Indians and the Law. New York: Penguin Group.

Dyer, Justin Buckley. 2012. Natural Law and the Antislavery Constitutional Tradition. New York: Cambridge University Press.

Dyer, Justin Buckley. 2013. Slavery, Abortion, and the Politics of Constitutional Meaning. Cambridge: Cambridge University Press.

Edwards, Lydia. 2006. "Protecting Black Tribal Members: Is the Thirteenth Amendment the Linchpin to Securing Equal Rights within Indian Country," Berkley Journal of African-American Law \& Policy 8: 122-xii.

Erman, Sam. 2018. Almost Citizens: Puerto Rico, the U.S. Constitution, and Empire. Cambridge University Press.

Fixico, Donald L. 1986. Termination and Relocation: Federal Indian Policy, 1945-1960. Albuquerque: University of New Mexico Press.

Fletcher, Matthew L.M. 2011. American Indian Tribal Law. Austin: Wolters Kluwer.

Fletcher, Matthew L.M. 2013. "Tribal Membership and Indian Nationhood," American Indian Law Review 37 (1): 1-17.

Foreman, Grant. 1974. Indian Removal. Norman: University of Oklahoma Press.

French, Laurence Armand. 2016. Policing American Indians: A Unique Chapter in American Jurisprudence. CRC Press.

Friedman, Andrea. 2014. Citizenship in Cold War America: The National Security State and the Possibilities of Dissent. University of Massachusetts Press.

Fritz, Henry E. 1963. The Movement for Indian Assimilation, 1860-1890. Philadelphia: University of Pennsylvania Press.

Gaines, Craig. 1998. The Confederate Cherokees: John Drew's Regiment of Mounted Rifles. Baton Rouge: Louisiana State University Press.

Glazer, Nathan. 1975. Affirmative Discrimination: Ethnic Inequality and Public Policy. New York: Basic Books.

Goodwin, Doris Kearns. 2005. Team of Rivals: The Political Genius of Abraham Lincoln. New York: Simon and Schuster. 
Grant, Ulysses S. 2010. "Second Inaugural Address," in The Complete Book of Presidential Inaugural Speeches: From George Washington to Barack Obama. Edited by Ian Randal Strock. Brooklyn: Grey Rabbit Publications.

Green, Michael D. 1982. The Politics of Indian Removal: Creek Government and Society in Crisis. Lincoln: University of Nebraska Press.

Gross, Emma R. 1989. Contemporary Federal Policy toward American Indians. New York: Greenwood Press.

Halliburton, R., Jr. 1977. Red Over Black: Black Slavery among the Cherokee Indians. Westport: Greenwood Press.

Hamilton, Alexander, James Madison, and John Jay. 1961. The Federalist Papers. New York: New American Library.

Hartz, Louis. 1991. The Liberal Tradition in American Politics. Orlando: Harcourt Books.

Hill, Sarah H. 1997. Weaving New Worlds: Southeastern Cherokee Women and Their Basketry. Chapel Hill: University of North Carolina Press.

Hoffman, Donna R. and Alison D. Howard. 2006. Addressing the State of the Union: The Evolution and Impact of the President's Big Speech. Boulder: Lynne Rienner Publishers.

Holt, Michael F. 1973. “The Democratic Party, 1828-1860,” in History of US Political Parties, Volume 1, 1789-1860, edited by Arthur M. Schlesinger, Jr. New York: Chelsea House.

Hoxie, Frederick E. 1989. A Final Promise: The Campaign to Assimilate the Indians, 1880-1920. Cambridge: Cambridge University Press.

Huntington, Samuel P. 2004. Who Are We? The Challenge to America's National Identity. New York: Simon and Schuster.

Jones, Martha S. 2018. Birthright Citizens: A History of Race and Rights in Antebellum America. Cambridge University Press.

Katznelson, Ira, and John S. Lapinski. 2006. "At the Crossroads: Congress and American Political Development." Perspectives on Politics 4 (2): 243-260.

Kettner, James H. 1978. The Development of American Citizenship, 1608-1870. Chapel Hill: University of North Carolina Press.

King, Gary. 1993. "The Methodology of Presidential Research," in Researching the Presidency: Vital Questions, New Approaches, edited by George C. Edwards III, 
John H. Kessel, and Bert A. Rockman. Pittsburgh: University of Pittsburgh Press. 387-412.

Krauthamer, Barbara. 2013. Black Slaves, Indian Masters: Slavery, Emancipation, and Citizenship in the Native American South. Chapel Hill: University of North Carolina Press.

Kruse, Line-Noue Memea. 2018. The Pacific Insular Case of American Samoa: Land Rights and Law in Unincorporated US Territories. Palgrave McMillian.

Kymlicka, Will. 1995. Multicultural Citizenship: A Liberal Theory of Minority Rights. Oxford: Clarendon Press.

Lapinski, John S. 2013. The Substance of Representation: Congress, American Political Development, and Lawmaking. Princeton: Princeton University Press.

Lauber, Almon W. 1913. Indian Slavery in Colonial Times within the Present Limits of the United States. New York: Longmans, Green, and Company.

Limerick, Patricia Nelson. 1987. The Legacy of Conquest: The Unbroken Past of the American West. New York: W. W. Norton.

Littlefield, Daniel F., Jr. 1977. Africans and Seminoles: From Removal to Emancipation. Westport: Greenwood Press.

Littlefield, Daniel F., Jr. 1978. The Cherokee Freedmen: From Emancipation to American Citizenship. Westport: Greenwood Press.

Littlefield, Daniel F., Jr. 1980. The Chickasaw Freedmen: A People Without a Country. Westport: Greenwood Press.

Locke, John. 1960. Two Treatises of Government. Edited by Peter Laslett. Cambridge University Press.

Locke, John. 1996. Some Thoughts Concerning Education and Of the Conduct of the Understanding. Edited by Ruth W. Grant and Nathan Tarcov. Indianapolis: Hackett Publishing Company, Inc.

Madison, James. 1981. The Mind of the Founder. Ed. Marvin Meyers. Hanover: University Press of New England.

Madison, James. 2015. "Memorandum on an African Colony for Freed Slaves." In Liberty and Equality: The American Conversation, edited by S. Adam Seagrave, 227-228. Lawrence: University Press of Kansas.

Maltzman, Forrest, James F. Spriggs II, and Paul J. Wahlbeck. 2000. Crafting Law on the Supreme Court: The Collegial Game. Cambridge: Cambridge University Press. 
Mandell, Daniel R. 2010. King Philip's War: Colonial Expansion, Native Resistance, and the End of Indian Sovereignty. Baltimore: Johns Hopkins University Press.

Mankiller, Wilma and Michael Wallis. 1993. Mankiller: A Chief and Her People. New York: St. Martin's Press.

McDonald, Forrest. 1985. Novus Ordo Seclorum: The Intellectual Origins of the Constitution. Lawrence: University Press of Kansas.

McDonald, Forrest. 1994. The American Presidency: An Intellectual History. Lawrence: University Press of Kansas.

McGovney, Dudley O. 1911. "American Citizenship. Part II. Unincorporated Peoples and Peoples Incorporated with Less Than Full Privileges." Columbia Law Review 11 (4): 326-347.

McLoughlin, William G. 1986. Cherokee Renascence in the New Republic. Princeton: Princeton University Press.

Minges, Patrick N. 2003. Slavery in the Cherokee Nation: The Keetoowah Society and the Defining of a People, 1855-1867. New York: Routledge.

Minges, Patrick N. Ed. 2004. Black Indian Slave Narratives. Winston-Salem: John F. Blair, Publisher.

Mooney, James. 1900. "Myths of the Cherokee." Smithsonian Institution, Bureau of American Ethnology, Washington, D.C.: G.P.O.

Morgan, Edmund S. 1975. American Slavery, American Freedom: The Ordeal of Colonial Virginia. New York: W. W. Norton.

Moulton, Gary E. 1985. "Editor's Introduction," in The Papers of Chief John Ross: Vol I, 1807-1839. Edited by Gary E. Moulton. Norman: University of Oklahoma Press, 3-11.

Nabokov, Peter. Ed. 1999. Native American Testimony: A Chronicle of Indian-White Relations from Prophecy to the Present, 1492-2000. New York: Penguin Group.

Neustadt, Richard E. 1990. Presidential Power and the Modern Presidents: The Politics of Leadership from Roosevelt to Reagan. New York: The Free Press.

Office of the Indian Rights Association. The Dawes Commission and the Five Civilized Tribes of Indian Territory, by Charles F. Meserve. Open-file report. Philadelphia, 1896.

Orren, Karen and Stephen Skowronek. 2004. The Search for American Political Development. Cambridge University Press. 
Orren, Karen and Stephen Skowronek. 2011. "Have We Abandoned a 'Constitutional Perspective' on American Political Development?” Review of Politics 73 (2): 295-299.

Perdue, Theda. 1979. Slavery and the Evolution of Cherokee Society, 1540-1866. Knoxville: University of Tennessee Press.

Purdue, Theda. 1998. Cherokee Women. Lincoln: University of Nebraska Press.

Perdue, Theda. 2000. "Clan and Court: Another Look at the Early Cherokee Republic." American Indian Quarterly 24 (4): 562-569.

Perdue, Theda and Michael D. Green. 2007. The Cherokee Nation and the Trail of Tears. New York: Penguin Books.

Perdue, Theda. 2016. The Cherokee Removal: A Brief History with Documents 3rd Ed. Boston: Bedford/St. Martin's.

Porter, Kenneth W. 1971. The Negro on the American Frontier. New York: Arno Press.

Prucha, Francis Paul. 1976. American Indian Policy in Crisis: Christian Reformers and the Indian, 1865-1900. Norman: University of Oklahoma Press.

Prucha, Francis Paul. 1981. Indian Policy in the United States: Historical Essays. Lincoln: University of Nebraska Press.

Reese, Linda W. 2002. “Cherokee Freedwomen in Indian Territory, 1863-1890.” Western Historical Quarterly 33 (3): 273-296.

Rolnick, Addie C. 2014. "Tribal Criminal Jurisdiction: Beyond Citizenship and Blood." American Indian Law Review 39 (2): 337-449.

Rosenblum, Nancy L. 2008. On the Side of the Angels. Princeton: Princeton University Press.

Rosenblum, Nancy L. 2006. "Replacing Foundations with Staging: Second Story Concepts and American Political Development," In Nature and History in American Political Development, edited by James W. Ceaser. Cambridge: Harvard University Press.

Ross, John. 1985a. The Papers of Chief John Ross: Vol I, 1807-1839. Edited by Gary E. Moulton. Norman: University of Oklahoma Press.

Ross, John. 1985b. The Papers of Chief John Ross: Vol II, 1840-1866. Edited by Gary E. Moulton. Norman: University of Oklahoma Press. 
Ross, John. 1985c. “Address to National Council, September 12th, 1893,” in The Papers of Chief John Ross: Vol I, 1807-1839. Edited by Gary E. Moulton, 760-762. Norman: University of Oklahoma Press.

Ross, John. 1985d. “To Montford Stokes, October 7th, 1839," in The Papers of Chief John Ross: Vol I, 1807-1839. Edited by Gary E. Moulton, 765-767. Norman: University of Oklahoma Press.

Saltz, Ronald N. 1975. American Indian Policy in the Jacksonian Era. Lincoln: University of Nebraska Press.

Saunt, Claudio. 2004. "The Paradox of Freedom: Tribal Sovereignty and Emancipation during the Reconstruction of Indian Territory." The Journal of Southern History 70: 63-94.

Seagrave, S. Adam. Editor. Liberty and Equality: The American Conversation. Lawrence: University Press of Kansas.

Segal, Jeffrey A. and Harold J. Spaeth. 2002. The Supreme Court and the Attitudinal Model Revisited. Cambridge: Cambridge University Press.

Shklar, Judith N. 1991. American Citizenship: The Quest for Inclusion. Cambridge: Harvard University Press.

Sides, John, Michael Tesler, and Lynn Vavreck. 2018. Identity Crisis: The 2016 Presidential Campaign and the Battle for the Meaning of America. Princeton University Press.

Skowronek, Stephen. 1997. The Politics Presidents Make: Leadership from John Adams to Bill Clinton. Cambridge: Belknap Press.

Skowronek, Stephen. 2008. Presidential Leadership in Political Time: Reprise and Reappraisal. Lawrence: University Press of Kansas.

Smith, Rogers M. 1997. Civic Ideals: Conflicting Visions of Citizenship in U.S. History. New Haven: Yale University Press.

Smithers, Gregory D. 2015. The Cherokee Diaspora: An Indigenous History of Migration, Resettlement, and Identity. New Haven: Yale University Press.

Squire, Peverill. 2012. The Evolution of American Legislatures: Colonies, Territories, and States, 1619-2009. Ann Arbor: University of Michigan Press.

Stremlau, Rose. 2011. Sustaining the Cherokee Family: Kinship and the Allotment of an Indigenous Nation. Chapel Hill: University of North Carolina Press. 
Strum, Circe. 1998. "Blood Politics, Racial Classification, and Cherokee National Identity: The Trials and Tribulations of the Cherokee Freedmen." American Indian Quarterly 22 (1/2): 230-258.

Sturm, Circe. 2002. Blood Politics: Race, Culture, and Identity in the Cherokee Nation of Oklahoma. University of California Press.

Sturm, Circe. 2014. "Race, Sovereignty, and Civil Rights: Understanding the Cherokee Freedmen Controversy." Cultural Anthropology 29 (3): 575-598.

Taylor, Charles. 1994. Multiculturalism: Examining the Politics of Recognition. Edited by Amy Gutmann. Princeton: Princeton University Press.

Taylor, Graham D. 1980. The New Deal and American Indian Tribalism: The Administration of the Indian Reorganization Act, 1934-45. Lincoln: University of Nebraska Press.

Taylor, Theodore W. 1983. American Indian Policy. Mt. Airy: Lomond Publications, Inc.

Thach, Charles C. The Creation of the Presidency, 1775-1789. Indianapolis: Liberty Fund.

Thornton, Russell. 1990. The Cherokees: A Population History. Lincoln: University of Nebraska Press.

Tocqueville, Alexis. 2000. Democracy in America. Edited and Translated by Harvey C. Mansfield and Delba Winthrop. Chicago: University of Chicago Press.

Trafzer, Clifford E. Editor. 2009. American Indians/American Presidents: A History. New York: Harper Collins.

Tulis, Jeffrey K. 1987. The Rhetorical Presidency. Princeton: Princeton University Press.

Tully, James. 1995. Strange Multiplicity: Constitutionalism in an Age of Diversity. Cambridge: Cambridge University Press.

U.S. Census Bureau. The American Indian and Alaska Native Population: 2010. Prepared by Tina Norris, Paula L. Vines, and Elizabeth M. Hoeffel. Washington DC: Government Printing Office, 2012.

Wardell, Morris L. 1938. A Political History of the Cherokee Nation, 1838-1907. Norman: University of Oklahoma Press.

Wax, Murray L. and Rosalie H. Wax. 1978. "Religion Among the American Indians." The Annals of the American Academy of Political and Social Science 436: 27-39.

West, Thomas G. 2017. The Political Theory of the American Founding. Cambridge: Cambridge University Press. 
Whyte, Kyle. 2017. "The Dakota Access Pipeline, Environmental Injustice, and U.S. Colonialism." Red Ink: An International Journal of Indigenous Literature, Arts, \& Humanities. 19 (1): 154-169.

Wilkins, David E. 1997. "With the Greatest Respect and Fidelity: A Cherokee Vision of the 'Trust' Doctrine." The Social Science Journal 34 (4): 495-510.

Williams, Robert A. 2005. Like a Loaded Weapon: The Rehnquist Court, Indian Rights, and the Legal History of Racism in America. Minneapolis: University of Minnesota Press.

Wilson, Walt. 1971. "Freedmen in Indian Territory during Reconstruction," The Chronicles of Oklahoma. Oklahoma Historical Society 49 (2): 230-244. 


\section{Vita}

Aaron Kushner was born in Columbus, OH on March 23, 1991 to Bob and Mary Ann Kushner. Aaron was homeschooled and graduated with his high school diploma in 2009. He earned his BA in Politics from Saint Vincent College in 2013, followed by an MA in Political Science from Northern Illinois University in 2015. He earned his PhD from the University of Missouri in the summer of 2019. In the fall of 2019, he began a post-doctoral fellowship at the Arizona Living Constitution Project, housed at Arizona State University. Aaron's primary research interest is citizenship, both as a legal condition and as a theoretical concept. He hopes that his research will lead him to work closely with indigenous peoples within the United States to help make indigenous political thought and the political realities of the tension between American politics and Native American governance more salient in scholarly discourse. Ditat Deus. 